\title{
Historic Indian Groups of the Choke Canyon Reservoir and Surrounding Area, Southern Texas
}

T. N. Campbell

Center for Archaeological Research

T. J. Campbell

Center for Archaeological Research

Follow this and additional works at: https://scholarworks.sfasu.edu/ita

Part of the American Material Culture Commons, Archaeological Anthropology Commons, Environmental Studies Commons, Other American Studies Commons, Other Arts and Humanities Commons, Other History of Art, Architecture, and Archaeology Commons, and the United States History Commons

Tell us how this article helped you.

This Article is brought to you for free and open access by the Center for Regional Heritage Research at SFA ScholarWorks. It has been accepted for inclusion in Index of Texas Archaeology: Open Access Gray Literature from the Lone Star State by an authorized editor of SFA ScholarWorks. For more information, please contact cdsscholarworks@sfasu.edu. 
Historic Indian Groups of the Choke Canyon Reservoir and Surrounding Area, Southern Texas

\section{Creative Commons License}

(c) (1) (8)

This work is licensed under a Creative Commons Attribution-NonCommercial 4.0 International License 


\section{HISTORIC INDIAN GROUPS OF THE CHOKE CANY ON RESERVOIR AND SURROUNDING AREA, SOUTHERN TEXAS}

VIEE PRESTIENT RQR

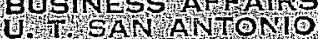

AECD NAR 21983

REFER IO

HANDLE., W. REA D \& RETIURN

T. N. Campleell and T. Campbel

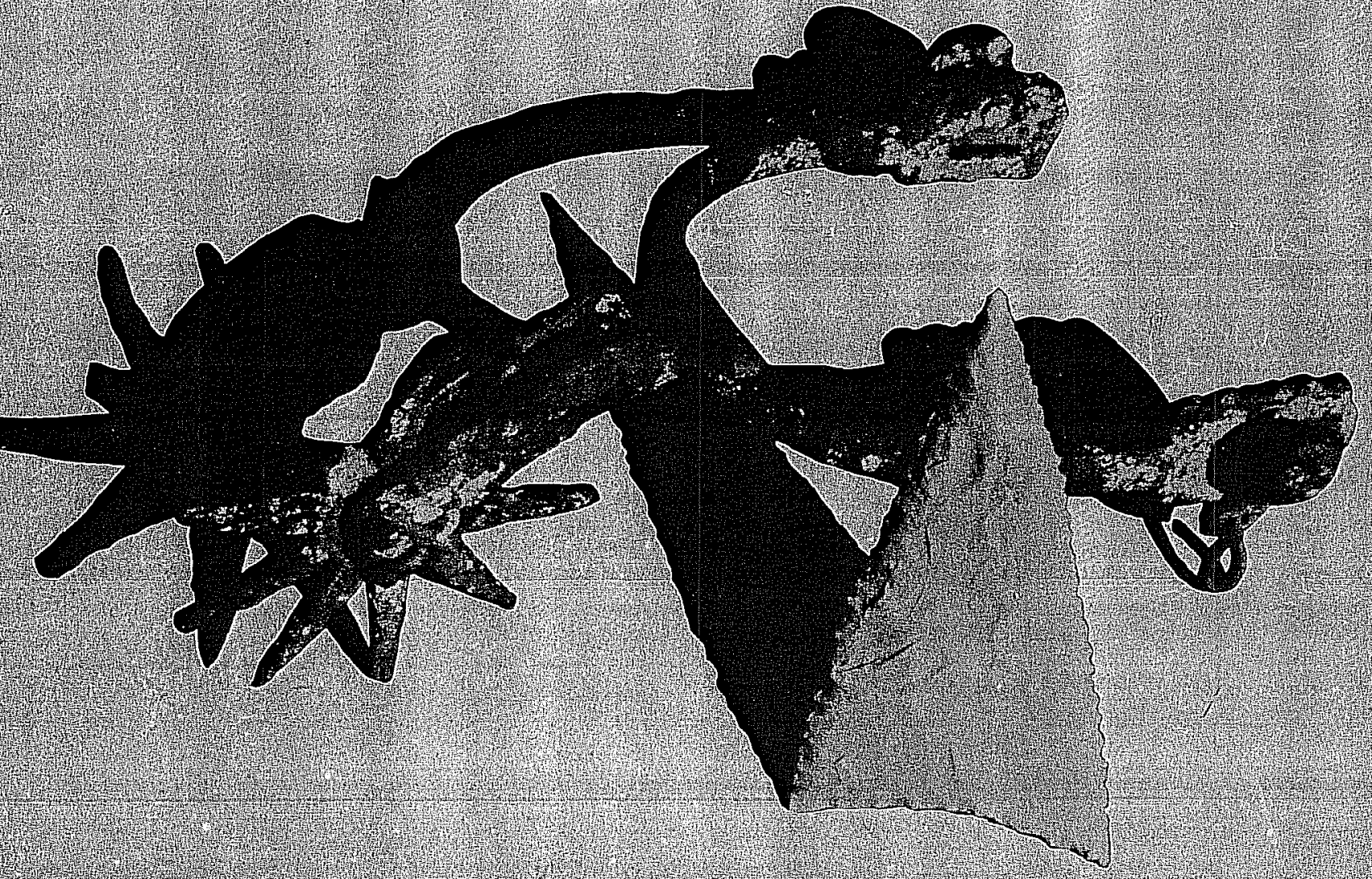

Center for Arehaeological Research

The University of Texas at San Antonio

Choke Canyon Series. Volume 

HISTORIC INDIAN GROUPS OF THE

CHOKE CANYON RESERVOIR AND

SURROUNDING AREA, SOUTHERN TEXAS

T. N. Campbe11 and T. J. Campbe11

Center for Archaeological Research The University of Texas at San Antonio Choke Canyon Series: Volume 1

1981 
Center for Archaeological Research

The University of Texas at San Antonio

78285

Thomas R. Hester, Director

Volumes in the Phase I Choke Canyon Series.

Volume 1 Historic Indian Groups of the Choke Canyon Reservoir and Surrounding Area, Southern Texas. By T. N. Campbe11 and T. J. Campbe11.

Volume 2

Part I - Historical Resources of the Choke Canyon Reservoir Area in McMullen and Live Oak Counties, Texas. By Diana Everett.

Part II - Historical Archaeological Resources of the Choke Canyon Reservoir Area in McMullen and Live Oak Counties, Texas. By Phillip A. Bandy.

Volume 3 An Archaeological Survey of a Portion of the Choke Canyon Reservoir Area in McMullen and Live Oak Counties, Texas. By Alston V. Thoms, John L. Montgomery, and Alice W. Portnoy.

Volume 4

The 1979 Archaeological Survey of Portions of the Choke Canyon Reservoir in Live Oak and McMullen Counties, Texas. By Erwin Roemer, Jr.

Volume 5

Archaeological Investigations at Choke Canyon Reservoir, South Texas: The Phase I Findings. By Grant D. Ha11, Carol Graves, and Stephen L. Black.

Volume $6 \quad$ Archaeological Testing and Collecting at Choke Canyon Reservoir, Nueces River Project, Texas. By Carol S. Weed and Harry J. Shafer.

Volume 7 Excavations at 41 LK 67, A Prehistoric Site in the Choke Canyon Reservoir, South Texas. By Grant D. Hal1.

Volume 8 Excavations at 41 LK 31/32 and 47 LK 202 in the Borrow Area of Choke Canyon Dam, South Texas. By Robert F. Scott, IV.

Volume 9 Phase I Archaeological Investigations at Choke Canyon Reservoir, South Texas: A Summary and Synthesis. By T. R. Hester and Grant D. Hall. 
List of Figures ....................

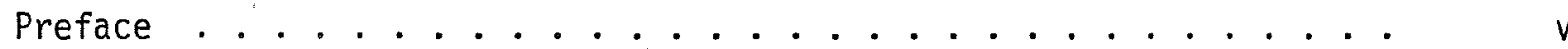

Introduction ..................... 1

Indians Known to Cabeza de Vaca . . . . . . . . . . . . 3

Basic Cabeza de Vaca Documents ................ 3

Route of Cabeza de Vaca in Southern Texas. . . . . . . . . 4

Locating Cabeza de Vaca's Indian Groups ... . . . . . . 9

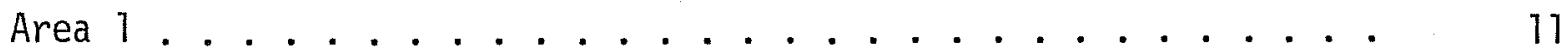

Guaycones .............................. 11

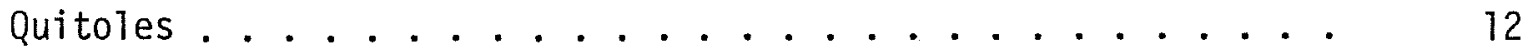

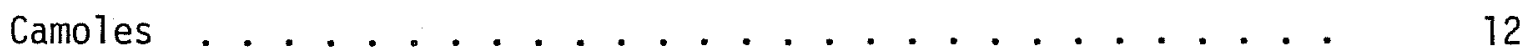

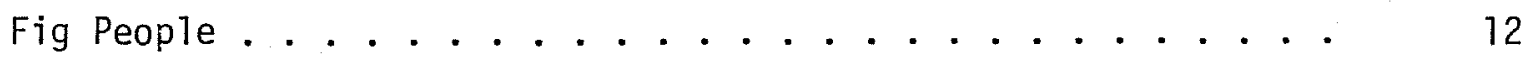

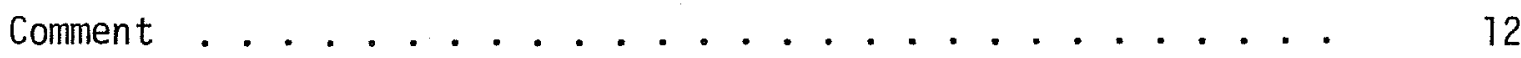

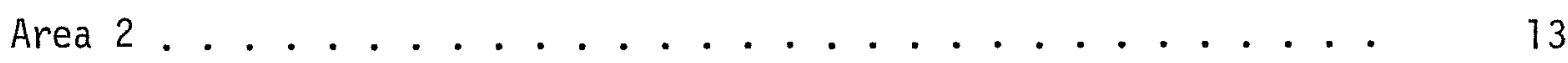

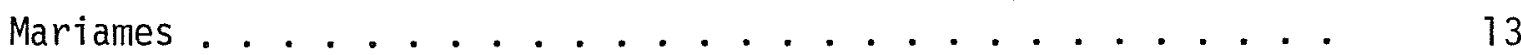

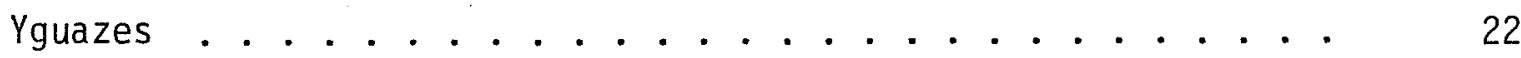

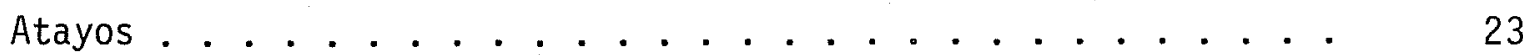

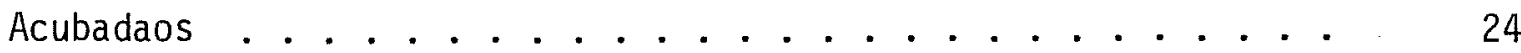

Avavares.......................... 24

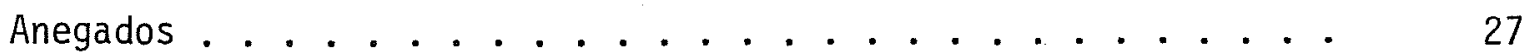

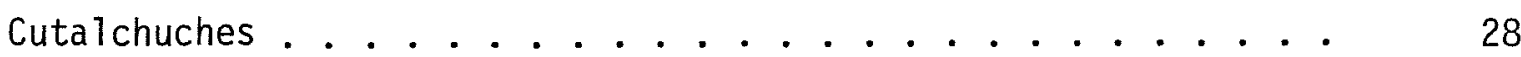

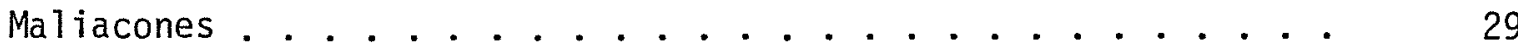

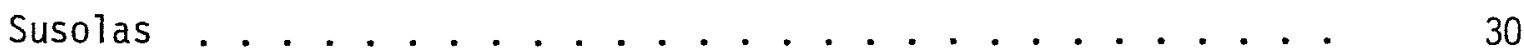

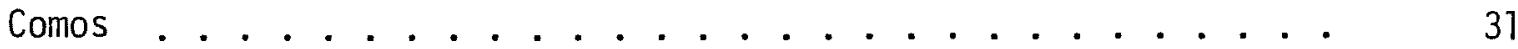

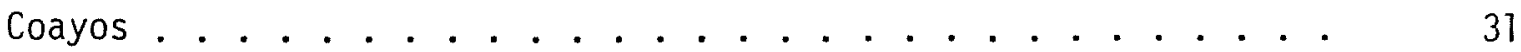

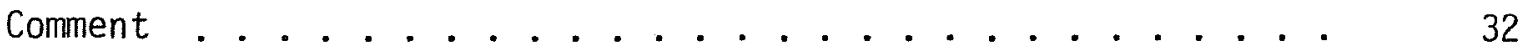




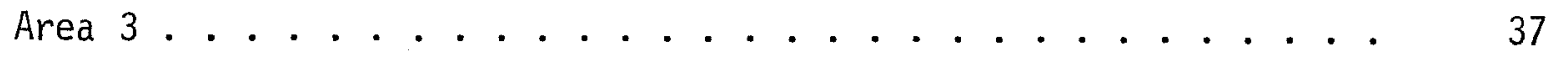

Arbadaos ........................ 38

Cuchendados ..................... 39

Comment ................. . . . 40

Indians known After the Time of Cabeza de Vaca . . . . . . . . . . 40

Groups Native to the Area ............... . . 41

Arcahomo ...................... 41

Orejón ............................ 41

Pacao .......................... 42

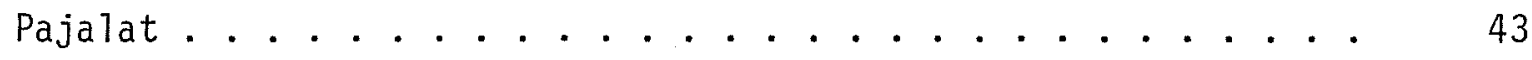

Pamaque ......................... 44

Pampopa .......................... . . 45

Pasnacan ........................... 48

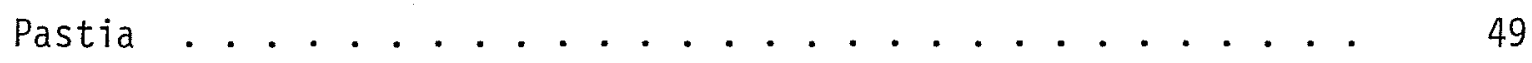

Patumaco .............................. 54

Piguique ........................ 54

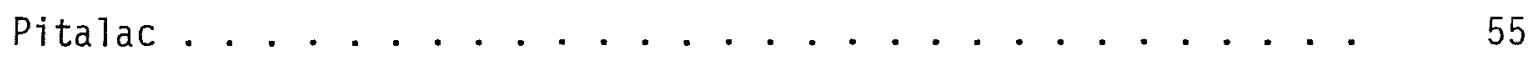

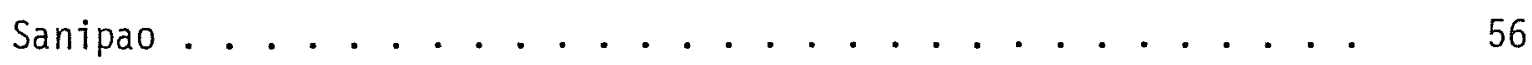

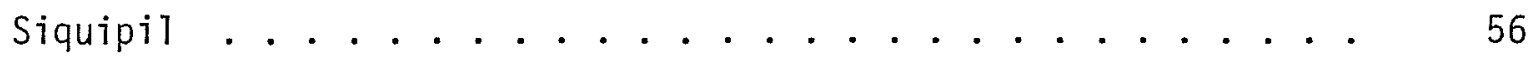

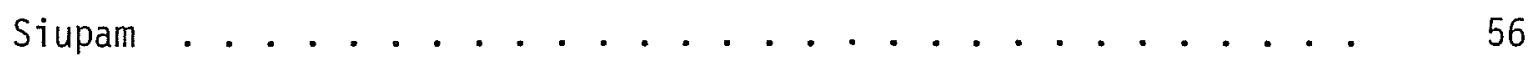

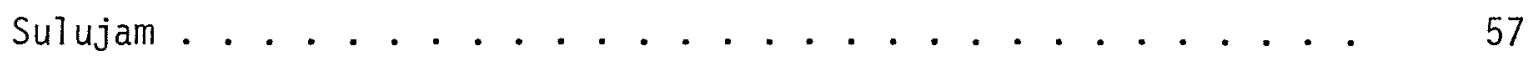

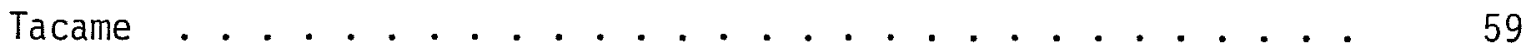

Tilpacopal ......................... 59

Comment ......................... 60

Immigrant Apaches ................. . . . . 62

Comment........................ 64 


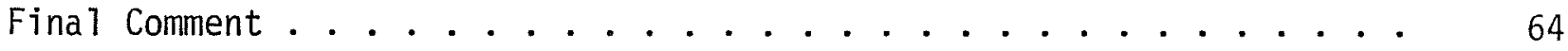

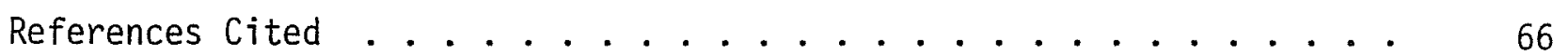

\section{LIST OF FIGURES}

Figure 1. Map of Southern Texas .............. 



\section{PREFACE}

This volume is the first in a series to be published on the archaeology, history and ethnohistory of the Choke Canyon Reservoir area in southern Texas. Intensive, coordinated cultural resource investigations have been underway in the reservoir basin since 1977, under the terms of Contract No. 7-07-50-v0897 (Nueces River Project), between the Center for Archaeological Research, The University of Texas at San Antonio and the Water and Power Resources Service (formerly the Bureau of Reclamation) of the United States Department of the Interior. Many agencies and individuals have been involved in these investigations, including Texas Tech University and Texas A\&M University, subcontractors for the Center during Phase I. Grant D. Hall has served as project director for the Center, while William J. Mayer-Oakes (Texas Tech) and Harry J. Shafer (Texas A\&M) have supervised the activities of research teams from their universities. Personnel of the Water and Power Resources Service have been extremely helpful, including the archaeological staff at the Amarillo office, Stephen Ireland, Van Button, and Meeks Etchieson; the contracting officer, M. B. Voth; and Tom Stotts (procurement). Allen C. Gates, project engineer, and his staff at Three Rivers, Texas have been of continuing help throughout the different stages of the project. Pete Aberle, Ron Mills, Bob Oram, and Bob Rowell have aided the research teams extensively. I would also like to acknowledge the hard work of Carol Graves, project editor at the Center, and the support and patience of secretarial staff, Mary Lou Ellis, Karen W. Scott, Mary Lehr, and Sylvia Bento.

One of the major facets of our investigations has involved a study of the ethnohistorical documents relating to the Indian inhabitants of the Choke Canyon area in Live Oak and McMullen Counties. Recent archaeological syntheses of southern Texas have documented more than 11,000 years of occupation by hunting and gathering peoples. The hunting and gathering 1 ifeway persisted into historic times, but was disrupted by the advancing Spanish frontier (exemplified by its mission system) and the incursions of Apache and, later, Comanche groups during roughly the same period. Thus, the hunters and gatherers of south Texas saw their way of life rapidly, and irrevocably, altered within the span of several decades. Spanish explorers, and particularly Spanish clergy working in the missions, managed to write down some observations on these aboriginal groups, though these were pitifully brief, usually consisting of notations about where a group was seen, a few word lists, comments on certain aspects of their culture, and a bewildering array of group names. One must remember that these small groups of hunters and gatherers were spread across a vast region, encompassing all of southern and south central Texas, as well as much of northeastern Mexico.

Linguists and anthropologists have struggled for many years to isolate, identify and describe these indigenous peoples. Names of languages (e.g., Coahuiltecan) have been proposed and rather indiscriminately applied as the names of many of the groups. Broad generalizations have been offered in describing the culture of these peoples, using bits and pieces of information from disparate geographic localities within the southern Texas-northeast Mexico area.

Fortunately, Thomas N. Campbe11 of The University of Texas at Austin has been deeply involved for some years now in a diligent, precise, and often tedious effort to elicit the best possible ethnohistoric summaries for many of these 
Indian groups. Since the early 1970s, a number of his studies have been published and now constitute a major resource for ethnohistorians and archaeologists.

The Center for Archaeological Research was indeed fortunate when Professor Campbe 11, aided by his daughter, Tommy Jo, agreed to undertake the task of extracting, assessing, and collating the ethnohistoric data for the Choke Canyon area. The document which has resulted, and which is appropriately published as the first in our series, is, I believe, a benchmark in ethnohistorical studies in southern Texas. Campbel1 and Campbe11 have done a thorough job, making clear the sources of their data, allowing us to brush aside the less precise research of earlier researchers. Moreover, they present a fresh examination of the travels of Alvar Nuñez Cabeza de Vaca, the first Spaniard to travel among the Indians of southern Texas. Historians and anthropologists have long struggled with the information presented by Cabeza de Vaca. The Campbe11s' knowledge of the region, its physiography and its Indian peoples contributes to an elegant discussion of Cabeza de Vaca's route and his observations on the Indian peoples. We are deeply grateful to the Campbells for their efforts.

Thomas R. Hester January 19,1981 
One of the principal objectives of the study reported herein has been to identify and present descriptive information recorded by Europeans about Indian groups who at various times during the historic period lived in or ranged over the area immediately surrounding the projected Choke Canyon Reservoir of southern Texas. This reservoir, located about 60 miles south of San Antonio, is associated with the lower Frio River above its junction with the Nueces River and lies within the northern parts of McMullen and Live Oak Counties. It has been the focus of recent archaeological investigation by the Center for Archaeological Research, The University of Texas at San Antonio.

The Choke Canyon Reservoir locality was not on any common route of European travel, particularly during the early historic period; and it is therefore difficult to identify by name very many of the Indian groups who, as hunters and gatherers, actually ranged over the lands that are to be inundated. The best that can be done is to discover the names of Indian groups seen or reported in the general area between the year 1528, when Europeans first penetrated the mainland of southern Texas, and the mid-nineteenth century, when the area was virtually cleared of all Indians that were either native to the area or were refugees from other areas.

In order to define a target area for documentary research, a circle with a 50-mile radius was drawn on a map of southern Texas, the modern community of Three Rivers serving as its center (Fig. 1). This inscribed circle includes all of Bee, Live Oak, and McMullen Counties and parts of all adjacent counties. An effort was made to examine enough historical documents to discover the names of all Indian groups who at various times were reported in or fairly close to the encircled area, and then to assemble such information as was recorded about them before their ethnic identities were lost.

The route (Fig. 1) of the earliest European traveler, Cabeza de Vaca, from the lower Guadalupe River southwestward to the summer prickly-pear collecting grounds of the Mariames and other Indian groups, appears to have crossed the peripheral portion of the target area in its southeastern quadrant. If the route interpretation is correct, it is possible to identify and plot the relative locations of certain Indian groups for the years 1534-1535. But it was not until the 1680s that Spaniards again visited this part of southern Texas, leaving a gap of approximately 150 years in the written records and making it especially difficult to establish continuities for its earliest known Indian groups. Actually the target area was seldom visited by Europeans until Spanish missions began to be built at San Antonio in 1718 and at Goliad in 1749. By this time, the general Indian population decline and territorial displacement by immigrant Spaniards and Apache Indians had disrupted the earlier group distribution patterns. The eighteenth-century documents are frequently vague about group locations and say very 7 ittle about languages spoken or cultural similarities and differences. After 1780 the truly aboriginal groups of southern Texas slowly disappear from primary records, except those which refer to remnants of various Indian groups stiil living at a few Spanish missions.

Since there is such a large time gap between the few Cabeza de Vaca documents and the more numerous documents of the later Spanish Colonial period, this 


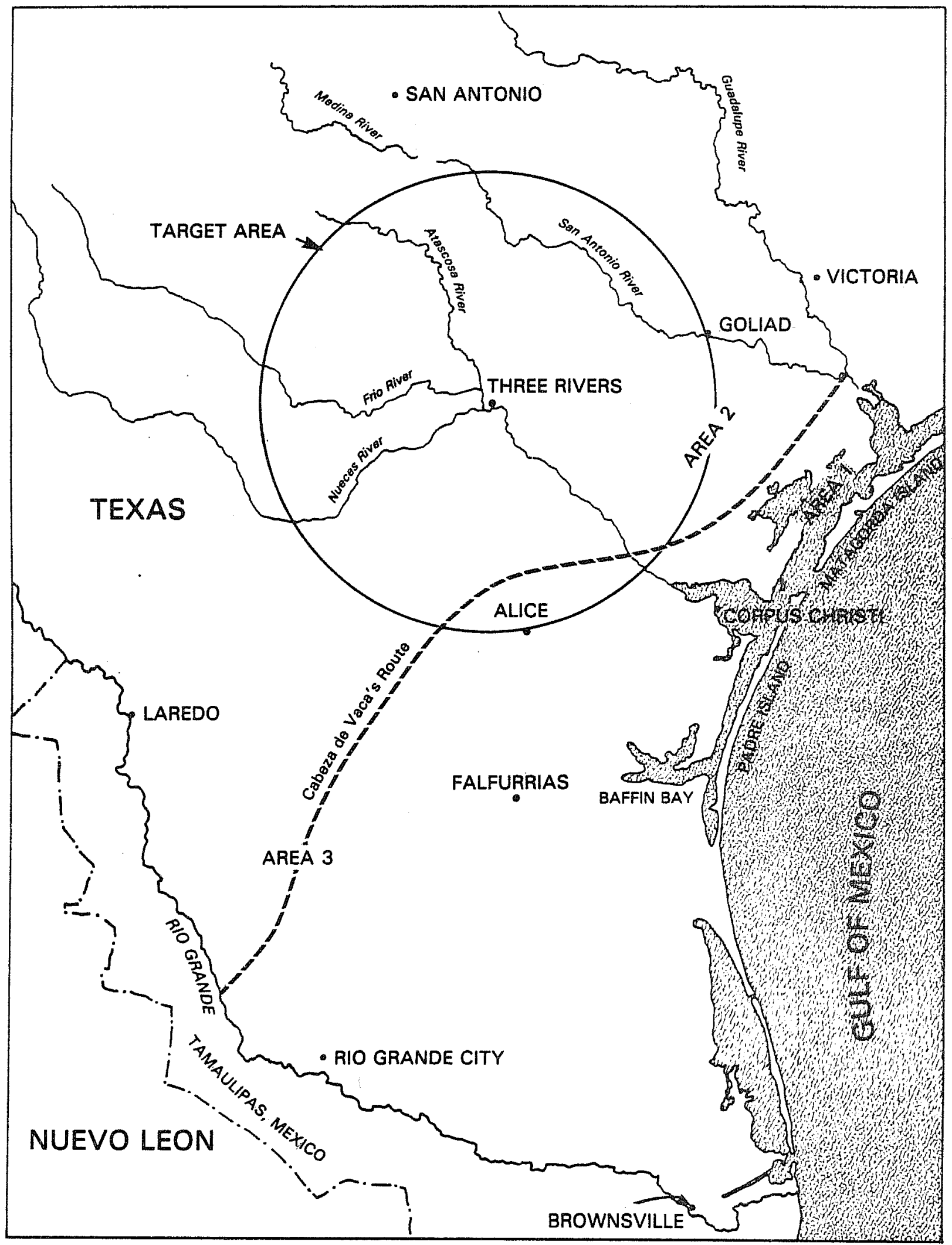

Figure 1. Map of Southern Texas. Shown are the Three Rivers target area, Cabeza de Vaca's probable travel route, and three areas with which most of Cabeza de Vaca's named Indian groups can be associated. 
report is presented in two parts, one covering the groups known to Cabeza de Vaca, the other covering Indian groups known after the Spanish settlement frontier had moved into what is now northeastern Mexico and southern Texas.

\section{INDIANS KNOWN TO CABEZA DE VACA}

The story of Cabeza de Vaca, treasurer of the Narváez expedition to Florida (1528), is well known. When Spanish ships failed to return to northwestern Florida for members of this expedition, five large barges were built, and the Spaniards proceeded along the northern coastline of the Gulf of Mexico, expecting to reach Pánuco, a settlement near present Tampico, Mexico. All five barges were blown ashore at various points on the coast of present Texas. Cabeza de Vaca's barge was wrecked late in 1528 on the beach of an island called Malhado which has sometimes been identified with Galveston Island, but which is more commonly identified with what is now an elongated peninsula that parallels the mainland just west of Galveston Island. After living with Indians on the island and with other Indians on the nearby mainland, Cabeza de Vaca in 1533 made his way on foot westward along the Texas coast to Indians known as Mariames who, for the greater part of each year, lived along a "river of nuts." It is now generally agreed that this "river of nuts" corresponds to the present Guadalupe River of Texas.

The lower Guadalupe River is the last locality on Cabeza de Vaca's route in Texas that is not controversial. Hence it is necessary to describe the basic Cabeza de Vaca documents and to call attention to internal evidence that is judged to be critical for determining the direction of Cabeza de Vaca's travel after leaving the lower Guadalupe River. The direction of travel controls the placement of Cabeza de Vaca's prickly pear collecting grounds, and this in turn controls the placement of certain Indian groups in or near the Choke Canyon target area.

\section{BASIC CABEZA DE VACA DOCUMENTS}

There are two basic sources of information on the Indians encountered by Cabeza de Vaca while traveling in Texas: (1) Cabeza de Vaca's personal narrative, and (2) a similar narrative, prepared by the historian Oviedo y Valdés, based on a joint report made by the few Narváez expedition survivors.

It is not certain just when Cabeza de Vaca completed his personal narrative, often referred to as Naufragios ("shipwrecks"), but records of the Hernando de Soto expedition indicate that Cabeza de Vaca had appeared at the Spanish Court with a written account some time prior to April 1538. It thus appears that Cabeza de Vaca's narrative, at least in some form, was written less than three years after he had left southern Texas, at a time when the experience was still fresh in his memory and when he was less than 48 years of age. So far as is now known, the narrative was first published in 1542 at Zamora, Spain. The original manuscript does not seem to have survived. Wagner $(1924: 29-30)$ has argued that the 1542 edition may have been an unlicensed pirated edition, but no copy of an edition published prior to 1542 has been found. A second and slightly altered edition was published at Valladolid, Spain, in 1555. Both 
editions have been translated into English and published in the United States (Bandelier 1905; Hodge 1907; Smith 1851). These have been reprinted one or more times.

After reaching Mexico City in 1536 and before arriving in Spain in 1537, Cabeza de Vaca and his associates prepared a report on the Narvaez expedition for the Audiencia de Española (Santo Domingo). This document is commonly referred to as the Joint Report, or the Oviedo account. A presumably amended version of this, believed to have been prepared in 1543 or 1544, was eventually published in Oviedo y Valdés's Historia General y Natural de las Indias (1853, Tomo III). The Oviedo account agrees with that of Cabeza de Vaca in narrative and descriptive detail, sometimes supplementing the Cabeza de Vaca account, but one notable difference is the absence of names for Indian groups. It is, however, relative$1 y$ easy to correlate the information on Indian groups given in these two documents. English translations of Oviedo's account have been published by Davenport (1924) and Hedrick and Riley (1974). Some students of Cabeza de Vaca's travel across southern North America have either been unaware of or have ignored the oviedo account.

A brief, truncated version of a third report, apparently written by Cabeza de Vaca, has also been published (Núnez Cabeza de Vaca 1870), but this contains nothing which does not also appear in the longer accounts of Cabeza de Vaca and Oviedo.

\section{ROUTE OF CABEZA DE VACA IN SOUTHERN TEXAS}

Interpretations of Cabeza de Vaca's general route of travel after coming ashore on the Gulf Coast of Texas have been numerous and varied, ranging from briefly stated guesses to lengthy presentations accompanied by scholarly, welldisciplined argument. The basic approach has been to search the Cabeza de Vaca documents for recorded detail on terrain features (islands, bays, rivers, mountains), plants, and animals, and then to use these in determining where Cabaza de Vaca was at the time of each successive observation. This approach has not always been pursued with rigorous objectivity. Some route interpreters have neglected to note that similar terrain features and biotic phenomena may be found in other areas through which Cabeza de Vaca may have passed. Contradictory evidence seems at times to have either been overlooked or ignored. In some cases it is obvious that Cabeza de Vaca has been made to go where the route interpreter wanted him to go, not where Cabeza de Vaca rather plainly indicates that he went. The cultural data recorded for Indian groups have seldom been used as criteria for route interpretation. Some Indian groups have been placed in areas that are not compatible with descriptions of their cultures. The total evidence to be found in the Cabeza de Vaca documents has not always been properly utilized in route interpretation.

The various interpreters of Cabeza de Vaca's route have managed to make him traverse nearly all the major sections of Texas. It is not feasible here to identify each route interpreter and present a critical review of his contribution. An excellent but still unpublished review of the more important route interpretations has been prepared by A. D. Krieger (1955) as part of a doctoral dissertation submitted to the Universidad Nacional Autónoma de México. A copy of this dissertation may be seen at the Barker Texas History Center, The University of Texas at Austin. 
The only route interpretations which can be given serious consideration fall into two categories: (1) those which interpret the route as proceeding from the lower Guadalupe River westward in slightly different directions to pass across Texas at its widest part, and (2) those which interpret the route as proceeding from the same river southwestward to cross the lower Rio Grande into northeastern Mexico before turning westward toward the Pacific coast of northern Mexico. The trans-Texas route is more popular and some version of it has been widely accepted by historians of Texas, although the trans-Mexico route is supported by much more of the evidence recorded in the Cabeza de Vaca documents. The trans-Mexico route has been convincingly demonstrated by Krieger in his doctoral dissertation and in a short article written in English but published in Mexico (Krieger 1961). There is nothing revolutionary about Krieger's interpretation, for it is essentially a refined version of the interpretation published much earlier by Davenport and Wells (1918-1919). Krieger was able to take advantage of better information on the landscape of northern Mexico and on its Indian populations during the Spanish Colonial period.

In order to justify our view that Cabeza de Vaca did not pass westward from the lower Guadalupe:River across Texas, we will summarize certain kinds of evidence, derived mainly from the Cabeza de Vaca documents, which support the interpretation that Cabeza de Vaca passed southwestward across southern Texas into northeastern Mexico before turning westward (Fig. 1). We accept that part of Krieger's interpretation which pertains to southern Texas, although we disagree with his location of Cabeza de Vaca's prickly pear collecting grounds.

Those who interpret Cabeza de Vaca's route as passing across Texas at its widest part pay minimal attention to Cabeza de Vaca's repeatedly stated initial objective, which was to reach the nearest known Spanish settlement, Pánuco, near present Tampico. When Narváez and his men, after building five barges, left what is now northwestern Florida in 1528, their plan was to follow the coastline of the Gulf of Mexico and thereby reach Pánuco. In 1519 Pineda had mapped the Gulf Coast from Tampa Bay to Pánuco, and the leaders of the Narváez expedition had seen this map and knew where Pánuco was. Narváez himself had been at Veracruz during the time of Cortés' conquest of Mexico. After two of the barges were wrecked on Malhado Island, some of the more sturdy survivors were sent ahead to walk along the coast to Pánuco, which they never reached. Later, when Cabeza de Vaca himself had moved farther down the Texas coast and had joined the Mariames on the lower Guadalupe River, he began to plan for the last four survivors to escape from their Indian captors, the Mariames and Yguazes, when they were gathering prickly pear fruit in an inland area to the southwest that was nearer to Pánuco than the lower Guadalupe River. If the prickly pear collecting area was not notably nearer to Pánuco, then the escape would have been made from the lower Guadalupe area. This is what makes it evident that the prickly-pear area was not due west or northwest of the lower Guadalupe River, as has been suggested by Krieger.

The Oviedo account appears to confirm this direction when it describes a communal deer hunt made by the Mariames when they were on their way to the prickly pear area. Deer were taken by being driven into the water of a coastal bay whose shores were being skirted. This was probably Copano Bay, whose long 
inland shoreline averages 18 miles from the open Gulf and is near a direct route from the lower Guadalupe River to the lower part of the Nueces River west and northwest of Corpus Christi Bay, where later sources indicate a localized superabundance of prickly pear fruit.

Cabeza de Vaca's escape plan involved the Spaniards leaving their Indian captors at the end of summer when the Indians were about to return to their winter range on the lower Guadalupe River and vicinity. Thus the Spaniards would escape and move in a southerly direction while the Indians were moving in the opposite direction. The Spaniards evidently assumed that the Mariames and Yguazes would not reverse their course and pursue the escapees.

The escape plan worked, and the four Europeans moved "forward" in the direction of Pánuco, that is, generally southward; and it was not until later, when they had crossed a large river and had seen their first mountains, that they decided to alter the original plan and move westward along a route that eventually took them across most of what is now northeastern, northern, and northwestern Mexico before turning southward again.

The lower Guadalupe River is identifiable as the "river of nuts" for several reasons. Local records indicate that native pecan trees have long been abundant along this river, growing almost to the head of San Antonio Bay. Those who have identified the "river of nuts" as the Colorado River neglect to note that Cabeza de Vaca places his "river of nuts" west of what is now Matagorda Bay and at least 30 leagues (78 miles) northeast of the prickly pear collecting grounds. The Colorado River is too far east on the coast to satisfy these locational and distance requirements.

The placement of Cabeza de Vaca's prickly-pear collecting grounds near the lower Nueces River is based on (1) the recorded distance from the lower Guadalupe River, (2) Oviedo's account of communal deer hunting on a coastal bay while the Mariames were en route to the prickly pear collecting grounds, (3) Cabeza de Vaca's repeated statement that he and his men were initially moving in the general direction of Pánuco, and (4) nineteenth-century observations on concentrations of prickly pear in southern Texas.

On a map, Krieger (1961:Fig. 1) has shown two routes from the lower Guadalupe River to the prickly pear area visited by Cabeza de Vaca and the Mariames. One of these is Krieger's preferred route; the other is designated as "alternative." The location of the Mariames' prickly pear area on the preferred route is at least 70 miles distant from the prickly pear area on the alternative route, although both areas are more or less equidistant from the lower Guadalupe River and agree with the distances of 30 or 40 leagues (78 or 104 miles) given respectively in the Cabeza de Vaca and Oviedo accounts.

Krieger's preferred route takes the Mariames generally westward, actually more northwestward, to a prickly pear concentration in present southern Atascosa and northern McMulien Counties ("perhaps 30 or 40 miles south of . . . San Antonio," [Krieger 1961:466]). This would place the prickly pear collecting grounds of the Mariames and other groups over 100 miles inland from the nearest portion of the outer shoreline of the Gulf of Mexico.

The alternative route of Krieger passes southwestward from the lower Guadalupe River, paralleling the coast at a distance of less than 50 miles from the open 
Gulf, to a prickly-pear collecting area west of Corpus Christi Bay, this area being marked on the map. This prickly pear area would be in the general vicinity of Alice in Jim Wells County and would probably include adjoining parts of western Nueces County and eastern Duval County.

Krieger's alternative route is strongly supported by the 0viedo account, which indicates that, while traveling to the prickly pear area, the Mariames stopped at one of the bays to take deer in considerable numbers by driving them into the sea to drown. The northwestern shore line of Copano Bay, with about 25 miles of beach, parallels this alternative route and is less than 20 miles from the route as designated by krieger. This route, as noted, would place the Mariames' collecting grounds west of Corpus Christi Bay, some 50 miles inland from the open GuTf. Its position is more in accord with Cabeza de Vaca's stated aim of taking advantage of Indian seasonal movements to move toward the Spanish settlement of Pánuco. Thus Krieger's alternative route seems much more reasonable than his preferred route, which implies that the Mariames went southwestward to hunt deer on a coastal bay while on their way to a prickly pear area located northwest of the lower Guadalupe River.

A number of nineteenth-century travelers refer to prickly-pear concentrations along the lower Nueces River and just south of it. Wrightman (Helm 1884:181), who at times (1824-1841) traveled south of the lower Nueces River, described much of the area as prairie with localized thick brush and prickly pear. The prickly pear is described as "immensely large and branching through which nothing can pass . . . acres covered with them . . . no man, no beast will attempt to penetrate them." In referring to the same area, Holley (1836:79-80) noted that prickly pear grew "in great abundance and forms in places impenetrable thickets higher than a man on horseback. It produces an immense quantity of fruit..." In 1842, while traveling from San Antonio to Laredo, Hendricks (1919:122) first encountered prickly pear thickets near the Nueces River somewhere in present La Salle County: "I for the first time beheld vast ramparts and towers of prickly pear that seemed to form walls and mountains in their terrible array." A few years later Bollaert (1850:15) noted that the prickly pear was especially abundant along Santa Gertrudis Creek somewhere south of present-day Alice, Texas.

At various times over 60 years ago, Davenport (Davenport and We11s 1918-1919: 209-211) collected information on prickly pear concentrations in southern Texas by interviewing numerous pioneers who had been in the area between 1860 and 1899, when a severe freeze greatly reduced prickly pear stands. His informants were in agreement that formerly the prickly pear plant grew in great profusion just south and west of the lower Nueces River in an area that includes parts of Live Oak, Duva1, Jim Wells, Nueces, and Kleberg Counties. Farther south, in the Sand Plain south and southwest of Baffin Bay, prickly pear was said to be relatively scarce. Davenport's informants also indicated that still farther south, or just north of the Rio. Grande in Cameron, Hidalgo, and Starr Counties, the prickly pear grew in even greater profusion than along the lower Nueces River. Bray (1901:379), a botanist who worked in southern Texas shortly after the freeze of 1899, mentions that in the lower Nueces Valley prickly pear "attains gigantic size, being said to exceed the height of ten feet."

These nineteenth-century observations are especially significant. They support the placement of Cabeza de Vaca's prickly pear collecting grounds near the lower 
Nueces River, and they also indicate that his prickly pear collecting grounds were not unique. They show that prickly pear concentrations existed farther to the west and also farther to the south. Cabeza de Vaca's prickly-pear concentration was evidently located on the northeastern edge of a large area that had similar localized concentrations. As will be noted later, this strongly suggests that the Indian groups encountered by Cabeza de Vaca in his prickly pear collecting grounds went there in summer from winter ranges that were located to the east and especially to the northeast of the lower Nueces prickly pear concentration. When Cabeza de Vaca and his three associates escaped from the Mariames and Yguazes in the prickly pear area and passed on to the Arbadaos and Cuchendados, they were proceeding in accordance with their plan to take an inland route southward toward Pánuco in order to avoid further contacts with shoreline groups. The treatment which various Spanish shipwreck survivors had received from shoreline Indians, from the Quevenes to the Camoles, explains why Cabeza de Vaca and his companions initially planned to follow an inland route toward Pánuco. Among those shoreline peoples, as well as among the Mariames and Yguazes, the Spaniards who had survived hunger and cold had been enslaved and made to do women's work. They had been slapped, cuffed, and beaten with sticks. They had been stripped of their clothing. Mud was sometimes thrown on them and their beards jerked out. For trying to escape, they had also been threatened with death, arrows had been shot into their limbs, and sometimes they had been killed outright. Some had also been killed because of native dream omens, and all the famished and weakened survivors of the Téllez-Peñalosa barge had been slaughtered. No Spanish survivor relished the thought of walking to Pánuco through additional groups of shoreline Indians.

Cabeza de Vaca's route after escaping from the Mariames in the prickly-pear area seems to have been more southwestward than southward, striking the Rio Grande in the vicinity of present Falcón Lake, as Krieger has argued. This direction was probably taken to avoid a distinctive area sometimes called the Sand Plain, with localized dune fields, that lies between Baffin Bay and the Rio Grande delta. This Sand Plain embraces most of Kenedy and Brooks Counties, as well as the eastern part of Jim Hogg County. In the Cabeza de Vaca narrative the references to terrain, vegetation, and surface water do not suggest that any part of the Sand Plain was traversed. Two groups, Arbadaos and Cuchendados, were encountered before reaching the Rio Grande, and these groups probably ranged over parts of the area just west of the Sand Plain. This general location seems to be confirmed by Cabeza de Vaca's clear statement that the first mountains were seen shortly after crossing the river.

The large stream crossed before seeing mountains was undoubtedly the Rio Grande, not the Colorado River, as claimed by most of the interpreters who prefer a trans-Texas route for Cabeza de Vaca. The same interpreters have identified the first mountains (sierras) seen by Cabeza de Vaca with the low hills along the eroded margin of the Edwards Plateau (Austin-San Antonio sector) instead of certain mountain ranges of northeastern Mexico, which Krieger has identified with the Cerralvo area of northern Nuevo León. On clear days the Cerralvo ranges are visible from the Falcón Lake area. Cabeza de Vaca cannot be charged with being careless in describing mountainous terrain. He grew up in southern Spain where the coastal ranges east of Jérez de la Frontera, his birthplace, rise to heights of 6,000 feet; and before writing his narrative Cabeza de Vaca had seen some of the highest mountains of western and southern Mexico. It is preferable to believe, as Krieger has stated, that Cabeza de Vaca was referring to elevations 
of greater magnitude than the hills of central Texas, which rise only a few hundred feet above the adjacent coastal plain.

Cabeza de Vaca and his associates carried the dread of shoreline Indians with them until they had crossed the Rio Grande and reached the mountains of northern Nuevo León. After leaving the Mariames and Yguazes, the Spaniards had passed through inland territories whose inhabitants had treated them well, primarily because of the Spaniards' success in curing Indian iliness. South of the Rio Grande food was more plentiful than it had been in southern Texas. It was when the Spaniards were at the foot of the mountains that a change in travel plan was made: they decided to travel westward before turning southward to Spanish settlements in lower Mexico.

Many route interpreters have Cabeza de Vaca turning westward and away from the coastal region at the prickly pear grounds to cross Texas north of the Rio Grande, which is very difficult to reconcile with the evidence contained in the basic documents. Cabeza de Vaca gives a plausible explanation for the change of direction when he was at the foot of the mountains. The change was made in order to avoid skirting the mountains southeastward and having to face shoreline Indians again. The Spaniards decided to go westward among Indians who were treating them well and seemed to have plenty of food. Furthermore, Cabeza de Vaca indicated that by traveling westward the Spaniards would have an opportunity to discover new lands and return to Spain with important information.

\section{LOCATING CABEZA DE VACA'S INDIAN GROUPS}

It wi11, of course, never be known precisely where Cabeza de Vaca encountered each Indian group in southern Texas. Today the best that can be done is to search the documents carefully for every detail that in some way seems pertinent to group location, and then to make full use of these details. For each group, one or more hypothesized locations can be tested by noting how much of the recorded detail confirms each location and how much contradicts it. It is especially important to maintain maximum objectivity concerning the interpretation of Cabeza de Vaca's general travel route and not to stray too far from internal evidence found in the documents.

As noted previously, ethnic group names are given in the narrative of Cabeza de Vaca but are omitted from the Oviedo account, al though the descriptive information contained in the two documents is essentially the same. These names are 23 in number, and all of them can be linked with the outer part of the Texas coastal plain, extending from the vicinity of Galveston Island to the vicinity of Falcón Lake, an overland distance of some 300 miles. From the Indian groups with which he lived at various times, Cabeza de Vaca must have learned the names of many groups that he failed to record. No group names are given by Eabeza de Vaca for the remainder of his travel route, a large part of which was across northern Mexico. It must be realized that, after being shipwrecked, Cabeza de Vaca lacked writing materials and could not keep a journal. It is regrettable that he failed to record at least some of the native group names for northeastern Mexico. If he had done so, a trans-Texas route probably would not have been suggested by anyone.

The most solid information on the relative locations of Indian groups is found in Chapter 26 of Cabeza de Vaca's narrative, in which he names 19 groups and 
arranges them in geographic order, beginning with Malhado Island and continuing westward along the coast to the lower Guadalupe River, then southwestward in the direction of Pánuco. A distinction is made between groups that lived along the shoreline and groups that lived immediately inland. A further ordering principle links each shoreline group with one or more groups that lived on the adjacent mainland. Elsewhere in the narrative, four additional group names appear that are not given in Chapter 26, making a total of 23 separate groups.

Fortunately, one anchor point on Cabeza de Vaca's route can be keyed into his group distribution record: the "river of nuts" or the Guadalupe River, along the lower part of which the inland Mariames lived. Beyond the Guadalupe River in the direction of Pánuco, all except two of the named Indian groups are connected with the prickly pear collecting area. This makes it rather clear that the relative locations indicated in Chapter 26 refer to the fall, winter, and spring territories of these seasonally migrating groups.

As the principal interest here is confined to groups that were nearest to the Choke Canyon Reservoir, no attention will be paid to six groups that lived east of the lower Guadalupe River. The six ignored groups consist of Capoques, Chorruco, Doguenes, Han, Mendica, and Quevenes. It cannot be established that any of these normally ranged west of either the lower Guadalupe River or the San Antonio Bay into which that river flows. Ignoring these eastern groups makes it possible also to ignore the various groups later recorded by French chroniclers of the La Salle expedition (1685) to the Matagorda Bay area.

Cabeza de Vaca has provided names for a total of 17 Indian groups that appear to have been distributed from the lower Guadalupe River southwestward toward the Rio Grande. The following excerpt from Chapter 26 (Valladolid edition) refers to this part of Cabeza de Vaca's route:

- Más adelante, en la costa, están los quevenes, y enfrente de ellos, dentro en la Tierra Firme, los mareames; y yendo por la costa adelante, están otros que se llaman guaycones, y enfrente de éstos, dentro en la Tierra Firme, los iguaces. Cabo de éstos están otros que se 1 laman atayos, y detrás de éstos, otros, acubadaos y de éstos hay muchos por esta vereda adelante. En la costa viven otros 1 lamados quitoles, y enfrente de éstos, dentro en la Tierra Firme, los avavares. Con éstos se juntan los maliacones, y otros cutalchiches, y otros que se llaman susolas, y otros que se 11 aman comos, y adelante en la costa están los camoles, y en la misma costa adelante, otros a quien nosotros 1 lamamos los de los higos... (Núñez Cabeza de Vaca 1971:68).

Cabeza de Vaca's 17 groups can be assigned to three areas (Fig. 1):

1. Area 1. Four groups that 7ived along the shores of coastal bays and islands: Camoles, Fig People, Guaycones, and Quitoles;

2. Area 2. Eleven inland groups that lived most of the year between the lower Guadalupe and lower Nueces Rivers but moved southwestward in summer to the prickly pear collecting grounds: Acubadaos, Anegados, Atayos, Avavares, Coayos, Comos, Cutalchuches, Maliacones, Mariames, Susolas, and Yguazes; 
3. Area 3. Two inland groups that lived southwest of the prickly-pear collecting grounds and not far from the Rio Grande: Arbadaos and Cuchendados.

Area 2 is of major interest because its inland groups are relatable to the Three Rivers target area. The groups of all three areas, however, will receive the same kind of treatment. It is hoped that this will reduce some of the confusion that has long prevailed concerning the relative locations of Cabeza de Vaca's Indian groups. In the sections that follow, all of the recorded information about each Indian group in these three areas is summarized. Failure to segregate, analyze, and synthesize this information has, in the past, led to a number of faulty generalizations about the earliest known Indian peoples of southern Texas.

It is not possible to link all of the cultural description in the Cabeza de Vaca documents with specific Indian groups. In Chapters 24-26 of Cabeza de Vaca's narrative, much cultural description is presented in a generalized way. It is referable, as noted above, to various Indian groups that lived along a section of the Texas coastal plain some 300 miles long, extending from the vicinity of Galveston Island to the vicinity of Falcon Lake on the Rio Grande. It does not appear reasonable to assume that every group encountered shared al1 the customary behavior described in these generalizing chapters. Onty when Cabeza de Vaca elsewhere in his narrative links some of the generalized behavior with specific groups can it be sorted out. The residue of generalized information has lesser value and must be used with proper caution, that is, always labelled for what it is. It is unfortunate for our purposes that Cabeza de Vaca economized and presented so much of his cultural information in an impressionistic manner.

Area 1

Cabeza de Vaca's narrative gives the names and relative locations of only four shoreline groups distributed southward from the lower Guadalupe River and San Antonio Bay. In order from north to south, these are: Guaycones, Quitoles, Camoles, and Fig People. After leaving the winter territory of the Mariames, Cabeza de Vaca traveled mainly inland, and his narrative does not report encounters with any of these shoreline Indian groups.

Guaycones. According to Cabeza de Vaca's statement on relative locations, the Guaycones were a coastal people who lived between the Quevenes and the Quitoles, with the Yguazes being their nearest inland neighbors. This would seem to place the Guaycones on the coast more or less south of the mouth of the Guadalupe River, which flows into the upper part of San Antonio Bay. Thus the most plausible location for the Guaycones is along the shoreline of the present Aransas National Wildlife Refuge and adjacent parts of Matagorda and St. Joseph Islands (Aransas and Calhoun Counties). Few writers have speculated about the location of the Guaycones. Baskett (1907:260-261) places the Guaycones in the area suggested here. Coopwood (1899-1900:122) suggests northern Hidalgo County, but this is much too far south to agree with Cabeza de Vaca's statements, as is also Lynn, Fox, and O'Mal7ey's (1977:Fig. 16) placement of the Guaycones on Baffin Bay. Davenport and Wells (1918-1919:136) equate the Guaycones with the "Guapites" (Coapites), which appears to be a guess based on slight similarity 
in the names and which cannot be taken very seriously. As the documents record nothing specific about the Guaycones culture, all that can be said is that if they lived on the coast, they were obviously adapted to a shoreline environment.

Quitoles. Cabeza de Vaca's statement on relative locations indicates that the Quitoles (this name is also rendered as Quitoks) were the next coastal people south-southwestward of the Guaycones, and that farther along the coast in the same direction were the Camoles. Our estimates lead us to place the Quitoles between the Copano and Corpus Christi Bays, an area that includes the mainland shores of southern Aransas County and eastern San Patricio County, as well as the adjacent parts of two offshore islands, St. Joseph and Mustang. This is where Baskett (1907:204) places them. Lynn, Fox, and 0'Malley (1977:Fig. 16) put them near Baffin Bay, which seems too far south to agree with the evidence recorded by Cabeza de Vaca about neighboring groups. Nothing further is recorded about the Quitoles.

Camoles. The Camoles (or Camones), according to Cabeza de Vaca's group distribution statement, were the next coastal people after the Quitoles, and beyond them farther southward were the Fig People. It is recorded that the Camoles killed the survivors of the Téllez-Peñalosa barge that was blown ashore in 1528. Spanish clothing and weapons were evidently traded to inland groups, for Cabeza de Vaca saw some of these items among the Anegados in 1534. It has been generally agreed that the Camoles lived in the vicinity of Corpus Christi Bay. Some route interpreters place the Camoles north of the bay (Baskett 1907:264; Castañeda 1936,I:59), and others place them just south of the bay (Lynn, Fox, and 0'Malley 1977:Fig. 16). The Camoles probably ranged a11 the shoreline of Corpus Christi Bay, as well as much of Mustang Island and the northern part of Padre Island.

Fig People. A Spanish name, los de los higos ("those of the figs"), was used for the last and southernmost coastline group named by Cabeza de Vaca, who reported that they lived farther along the coast toward Pánuco than the Camoles, who probably lived around Corpus Christi Bay. He learned from the Avavares that two Spanish shipwreck survivors had been seen among the Fig People, and this seems to indicate that these Fig People did not live very much farther down the coast than Corpus Christi Bay. Baskett (1907:263-264) places the Fig People on both sides of the Nueces River near its mouth on Corpus Christi Bay, but this is because he mistakenly assumes that the name Fig People refers to all the Indians who went inland to gather prickly pear fruit. Cabeza de Vaca certainly does not imply this. Bishop (1933:107) guesses that the Fig People may have lived near the mouth of the Rio Grande. It seems more reasonable to assign the Fig People to the coast somewhere not too far south of the Camoles, perhaps just south of Corpus Christi Bay. If this is correct, their territory may have included nearby portions of Padre Island. Placement of the Fig People any farther south than this makes it more difficult to explain their apparent contacts and communication with the inland Avavares. After leaving the Avavares, the four Spaniards seem to have followed a route that took them too far inland to learn about coastal groups between Baffin Bay and the mouth of the Rio Grande.

Comment. Very little about these four shoreline groups can be learned from the Cabeza de Vaca documents. How far inland they may have ranged is uncertain, but it is perhaps significant that Cabeza de Vaca encountered no shoreline groups 
in the prickly-pear collecting grounds. Apparently food was plentiful along the coast in summer, and prickly pear fruit did not attract them. No hostilities between shoreline and inland groups are mentioned. There is indication of friendly contacts between inland groups and shoreline groups, with the inland groups (Anegados and Avavares) apparently visiting the coastal groups. Trade between Camoles and Anegados is implied. These contacts suggest that the groups involved may have had adjoining territories.

Area 2

The 11 groups of this area, as already stated, are referred to in connection with seasonal migration to the prickly pear collection grounds; and of all of Cabeza de Vaca's named groups, these lived closest to the Three Rivers target area. Far more is recorded about the Mariames and Avavares because Cabeza de Vaca actualiy lived with these two groups and knew more about them. In the following pages these groups are treated roughly in the order of their locations along a northeast-southwest axis.

Mariames. Cabeza de Vaca was among the Mariames for at least 18 months during the years 1533-1534; and another Spanish shipwreck survivor, Andrés Dorantes, was among the Mariames even longer, about four years. In the two basic documents, the Mariames are the best described of all the Indian groups encountered by Cabeza de Vaca and his fellow travelers.

In English translations of the Cabeza de Vaca account, the original lengthy paragraphs have been broken up into shorter ones, and this has introduced a certain amount of ambiguity into the Mariame record. The lead sentences of two paragraphs (see Hodge 1953:65) contain the name Yguazes, making it appear that the cultural description that follows in each paragraph refers to the Yguazes; although it actually refers to the Mariames. Cabeza de Vaca lived among the Mariames, not among the Yguazes; and all of his cultural data in the two paragraphs refer to the Mariames, except where he notes that both groups practiced female infanticide. The internal documentary evidence indicates that Cabeza de Vaca's narrative at this point is describing the culture of the Mariames and merely includes a few statements about the Yguazes, some of which do not even refer to cultural characteristics. It is this unfortunate paragraphing change that has misled many students of the Cabeza de Vaca narrative (Coopwood 1899-1900:230-231,240; Hallenbeck 1940:64; Hodge 1910, II:997; Krieger 1961:464; Newcomb $1961: 37,40-41,46,49)$.

The documentary evidence on the territorial range of the Mariames is so clear that most writers associate these Indians, for about nine months of the year, with the lower Guadalupe River valley, particularly in the vicinity of its junction with the San Antonio River (Baskett 1907:260,264; Bishop 1933:87; Davenport and We11s 1918-1919:142,211; Krieger 1955:Fig.5 and 1961:466; Termer, in Núnez Cabeza de Vaca, 1963:156). Krieger has them ranging from the lower Guadalupe River eastward, but this is because he assumes that Cabeza de Vaca's Mariames were the same people as the Aranamas of the later mission period, which is very doubtful, as will be shown later. The documents lend little support to Mariames ranging very far east of the lower Guadalupe River. Two other placements cannot be taken seriously: that of Coopwood (1899-1900:122), which 
locates the Mariames in northern Hidalgo County not far from the Rio Grande; and that of Covey (1961:69-70), which puts them on the lower Colorado River.

Cabeza de Vaca who, along with Andrés Dorantes, learned to speak the language of the Mariames, says that it was different from that of the Quevenes, who lived on the nearby coast. He also says that the language of the Mariames was different from that of the Avavares who lived in or near the prickly pear collecting grounds. Some writers have speculated that the Mariames may have spoken a Tonkawan language (Davenport and We11s 1918-1919:138-139; Swanton 1940: 136 and 1952:226), but no linguistic evidence has been found to substantiate this.

Cabeza de Vaca says little about the physique of the Mariames, but he does note that they were not as big (grande) as their coastal neighbors, the Quevenes. In one household in which Cabeza de Vaca lived, all the individuals (at least five specified) were said to be blind in one eye. Nothing else is said about this puzzling phenomenon.

A11 of the recorded evidence indicates that the economic system of the Mariames was based upon hunting, fishing, and collecting wild plant products. Cabeza de Vaca states that no plants were cultivated.

The Mariames spent approximately nine months of the year (fall, winter, spring) along the lower Guadalupe River in an area that probably includes at least parts of three present-day Texas counties: Calhoun (northwestern), Refugio (northeastern), and Victoria (southern). The Oviedo account indicates that the Mariames frequently moved their encampments up or down the wooded river valley, but it never specifies just how far up or down the river they ranged. Hunting parties now and then penetrated the prairie lands on each side of the wooded floodplain.

The remainder of the year (summer) the Mariames occupied a distant area where prickly-pear plants grew in great profusion and whose fruits became a summer staple food. This area was probably in parts of Duval and Jim Wells Counties west of the Nueces River. Since there is no clear indication that the Mariames ranged widely over the prickly pear area, it seems reasonable to conclude that they confined themselves to some portion of it that was nearest to their Guadalupe River homeland, possibly the area north and northwest of present Alice, Texas. Placement of their prickly pear collecting area this far south is supported by Oviedo's account, which indicates that their route to prickly pear country took them close to a bay where the Mariames killed quantities of deer by driving them into saltwater. The long northwestern shoreline of Copano Bay is adjacent to the most direct route from the lower Guadalupe River to the postulated prickly pear collecting grounds. Oviedo states that after killing the deer the Mariames left saltwater and proceeded inland, presumably continuing in a southwesterly direction. According to interview data presented by Davenport and We11s (1918-1919:209-211) from individuals who had lived in southern Texas as early as 1860 , the greatest concentration of prickly pear plants nearest to the Mariames was in Duval and Jim Wells Counties, particularly between San Diego and Alice on the north and Falfurrias on the south. For these reasons it is believed that the Mariames did not go to get prickly pear fruits in Atascosa and McMulien Counties, as claimed by Krieger, but farther to the south, which was in the direction of Pánuco, Cabeza de Vaca's planned destination.

The documents thus seem to indicate that the Mariames, as well as some of their neighbors, exploited the food resources of two discrete inland areas separated 
by a distance of at least 80 miles. The space between the two areas was exploited only to the extent of foraging along a narrow corridor of travel twice a year. Bilobate territories of this sort, with a time differential in exploitation, and not always occupied exclusively by a single group, are obviously too complex to be shown on a conventional ethnographic map.

For the Mariames, both Cabeza de Vaca and Oviedo comment on intermittent food shortages and hunger. It is said that during the winter season these people sometimes went three or four days without food, and it was not unusual for them to search for food from dawn to dusk. Yet it is of interest to note that these sources never refer to individuals among the Mariames as being debilitated by malnutrition or dying as the result of it. Cabeza de Vaca, in commenting on all the Indians he knew in present southern Texas, says that they were good at enduring hunger, thirst, and extremes of temperature. It appears that the Mariames, like hunting and gathering populations elsewhere in the world, were well adjusted to an alternation of abundance and scarcity of natural foodstuffs.

It is possible that, when Cabeza de Vaca was among the Mariames in 1533-1534, annual rainfall was considerably below the present average for their Guadalupe River area; in other words, a drought may have been involved. The Mariames may have ranged up and down their river valley simply because the prairies on each side of the river were too dry at the time to support much game. Although Cabeza de Vaca mentions bison, he describes no bison-hunting parties. Just before joining the Mariames, Cabeza de Vaca asked the nearby Quevenes about the inland area to the west of them, and he was told that there was nothing to eat and the country was thinly occupied by people. The documents do not seem to be describing southern Texas at a time when rainfall was normal or above normal.

Several factors may have operated to prevent overpopulation among the Mariames. It is clearly stated that female infanticide prevailed. At birth, female children were abandoned (to be eaten by dogs, Cabeza de Vaca says). When questioned by Spaniards about female infanticide, the Mariames rationalized the custom. As they were ethnically exogamous, they did not want female children to grow up and marry enemy males, which would increase enemy populations. Apparently the Mariames regarded many surrounding groups as either enemies or potential enemies.

Although the number was sma11, some male children were killed because of dream omens (discussed later). Another factor was a form of birth control. Cabeza de Vaca states that, among all the Indians he knew in present southern Texas, men refrained from sexual intercourse with their wives from the time of conception until the child was about two years of age. Among the Mariames this would refer only to male children, as female children were not permitted to live.

The surviving documents say little about Mariame population size. Dorantes is quoted by Oviedo as saying that on one occasion he saw 60 males, presumably all adults, engaged in shoreline hunting. Since the context suggests that all of the Mariames were in the same place (they were on their way to the summer prickly pear harvesting grounds), it is possible to estimate the total population as not exceeding 200 individuals, allowing for female infanticide. No reference is ever made to more than one local group of Mariames. Cabeza de Vaca, in referring to a family with which he lived, says that it consisted of a man, his wife, 
his sons (number unspecified), and one other individual (possibly a relative). This particular household thus consisted of at least five individuals. If it is assumed that this family was of average size, it may be estimated that the Mariames, when all were in one place at the same time, may have had less than 40 houses in a temporary settlement.

The poorly described houses were probably round in floor plan, since the framework is said to consist of four poles (arcos), apparently flexible, because both ends of each pole were set in the ground. This presumably domed framework was covered by mats (esteras). House size is not recorded. The poles and mats were transported when encampments were moved, which is said to have happened every two or three days.

Nothing is said about garments except that some robes (mantas) and moccasins (zapatos) were made of bison skins, the former from skins of immature bison, the latter from older bison. Ornaments are implied by the statement that in males one nipple and a lip were perforated. As similar forms of bodily mutilation were described earlier by Cabeza de Vaca for a coastal population over 100 miles east of the lower Guadalupe River, it may be inferred that similar forms of ornaments were inserted in the perforations by Mariames. In the eastern group the nipple was perforated horizontally for insertion of a section of cane or bone (caña) some 20 inches long and about 1.5 inches in diameter. In the lower lip a similar perforation held a piece (pedazo) of cane or bone said to be half the size of a human finger.

Firewood and water were readily available in the valley of the Guadalupe River, but these were said to be scarce in the adjacent prairie lands. This is implied by Cabeza de Vaca's statement that, on occasional two-day hunting trips into nearby grasslands, firewood and water were transported for overnight use. In the prickly pear collecting grounds, where there were few perennial streams, it is said that the Mariames drank ponded rainwater or, when this was not available, prickly pear fruit juice.

Cabeza de Vaca makes it clear that the Mariames were plagued by three kinds of mosquitoes during the warm months, particularly at night, and that they built smudge fires around their sleeping places when it was feasible. In order to produce smoke, wet decayed wood was added to the fires from time to time. Cabeza de Vaca himself was sometimes forced to keep such fires going at night and was awakened by blows if he fell asleep and let the smoke get too thin. He notes that the Indians' bodies were at times so inflamed by mosquito bites that they appeared to have leprosy.

Cabeza de Vaca implies that bison sometimes came as far south as the winter territory of the Mariames, since he describes bison at the close of his section on the Mariames. It seems evident from his remarks that bison were not particularly important as a food resource, although he does say that bison skins were used for robes, footgear, and shields. The presence of bison in the Mariames' winter range is confirmed by documents of the La Salle expedition of 1686-1687, which indicate that the French colonists killed bison in considerable numbers just north of present Lavaca Bay, or less than 40 miles east of the lower Guadalupe River (Stiles 1906:passim)

The basic sources seem to agree that deer (venados) were obtained for food only now and then. Deer are not specifically mentioned in connection with Mariame 
prickly-pear fruit collecting in summer, and few deer seem to have been available elsewhere in mid-winter. It is said that so many other Indian groups came to the Guadalupe River valley to collect nuts that they killed off or frightened away all large game in the area.

Several approaches to deer hunting are described. Perhaps the most common one was for a male individual to run a deer long enough for the animal to become exhausted. It is said that a man could keep a deer on the run all day and finally run it to the ground or overtake it with a short burst of speed just before it fell exhausted. Burning vegetation in open prairie country was used to control movements of the deer, forcing the animals to seek food in certain unburned areas where they could be more easily killed. This would have had to be done when grass was dry enough to burn.

Special two-day hunting trips for deer and other unspecified animals were made two or three times a year. Such trips involved leaving the wooded river valley and going out into the adjacent grasslands. Wood and water, as noted above, were carried for this overnight trip. The hunting parties evidentiy went out in spring and fall, because the wood was used not only for cooking fires but also for smudge fires to keep off mosquitoes.

The Oviedo account describes a different approach to deer hunting that was used when the Mariames skirted a coastal bay on their way to the prickly pear collecting grounds in early summer. It may be surmised that the locale was along the northwestern shoreline of Copano Bay in Refugio County. It is said that this locality was not occupied by other Indians and that deer were sometimes numerous there. When an offshore breeze was blowing, males spread out and drove deer into the bay, keeping them there until they drowned and the carcasses were washed ashore. Krieger (1956:54) states that canoes were used to keep the deer from coming ashore, but the documents do not mention use of canoes for this purpose. The Mariames were on their way by land to the prickly pear collecting territory and would not have taken canoes with them. Although this kind of deer hunting seems to have been done but once a year, it sometimes yielded a large number of animals. Oviedo cites Andrés Dorantes as saying that the Mariames had varying degrees of success. Sometimes no deer were taken, or only a few, but at other times the number was quite large. One specific statement is made about an occasion when 60 men took 200 to 300 deer. Another statement mentions 500 deer taken, but the number of hunters is not given.

Fish were obtained from the Guadalupe River, but nothing is said about methods of fishing. Small nets are mentioned, although not in connection with economic activity. Apparently fish were eaten in quantity only during the April-May flood season, when they were obtained from shallow floodplain pools after floods had subsided. Fish bones were saved, ground to powder, and eaten.

Other life forms were consumed as food, including rats and mice, the former said to be especially numerous between the rivers, apparently meaning between the Guadalupe and San Antonio Rivers above their junction near San Antonio Bay. Snakes were eaten, including the rattlesnake; and bones of snakes, like those of fish, were saved, pulverized, and eaten. Snails were eaten when the Mariames were in the prickly pear grounds. Cabeza de Vaca does not mention snails as food in his account, but that of Oviedo notes that prickly pear fruits and snails were the main foods in the summer season at the prickly pear grounds. 
The snails, Oviedo says, were searched for carefully. Insects of various unspecified kinds were eaten, some in larval form, and ant eggs are mentioned. Other animal foods, especially in the lower Guadalupe River area, were frogs, lizards, salamanders, and spiders. The Mariames had dogs, mentioned in connection with female infanticide, but nothing is said about dogs being eaten. Other "foods," mentioned as being eaten when food of any kind was scarce, include earth (tierra), wood (madera), and deer droppings (estiércal).

Pecans, referred to as walnuts in the documents (in Cabeza de Vaca's time a specific word for pecan had not yet come into the Spanish language), constituted the dominant foodstuff for one to two months in the fall season, but only when trees produced nuts in abundance. The trees, said to be large and numerous along the Guadalupe River, did not produce in quantity every year. When the nut crop was good, it is mentioned that ethnic groups (none except Susolas identified by name) came from considerable distances, up to 50 or 75 miles, to eat pecans. Undoubtedly pecans were eaten separately, but Cabeza de Vaca says that nut meats were ground with small seeds (granillos) of some sort and eaten. No mention is made of storage of excess pecan nuts for later use. The Mariames, along with other groups, apparently ate their way through the pecan groves when nuts were available.

No mention is made of Mariames eating prickly pear fruits while in the Guadalupe River valley. The prickly pear collecting grounds are said to have been some 30 to 40 leagues (78 to 104 miles) from the Guadalupe River. Cabeza de Vaca states that the Mariames went to the same locality in each of the two summer seasons he spent with them.

The duration of the fruit-ripening season is given as three months by Cabeza de Vaca and one and one-half to two months by Oviedo. Cabeza de Vaca's statements clearly place the season between late May or early June and late in August. He describes the pears as hen-egg in size and either black or bright red in color. The fruit was commoniy eaten while it was being picked or shortly thereafter in the encampment. It is stated, however, that prickly pear fruits were dried for consumption during the return journey to the Guadalupe River. The juice of the fruit was squeezed out, the fruits opened, dried in the sun, and thereafter carried in some kind of flexible container. It is also said that the peelings of fruit were ground to a powder. When water was not locally available in the prickly pear area, the Mariames expressed fruit juice into a hole in the earth and drank it as a water substitute. Cabeza de Vaca comments on its sweet taste.

Roots of unidentified plants were an important source of food during the winter months, when many other foodstuffs were not available. Cabeza de Vaca says that the Mariames could not have survived in winter without roots. "Two or three" kinds of roots were dug by women. Plants with edible roots were thinly distributed, hard to find, and difficult to dig out. It is said that women searched areas around an encampment for distances of two or three leagues (five to eight miles), beginning the search at daybreak. Roots were cooked for two davs in some sort of oven, probably a shallow pit oven. Women spent considerable time each night preparing ovens for baking roots. Some roots are described as being very bitter and causing the abdomen to swell.

Although no tools are named or described, several kinds may be inferred: flint flakes, knives, and scrapers for skinning, butchering, and processing animal 
hides; digging sticks for collecting roots; and mortars and pestles for mashing pecan nutmeats with added small seeds, for pulverizing bones of fish, snakes, and other small animals, as well as dried prickly pear fruit peelings.

One kind of net is described as being one fathom (about 5.5 feet) in both length and width. Its function is not given, but it could have been used for transporting roots or for dipping small fish from floodplain overflow pools. Much matting must have been made, since it was used to cover house frames.

Pottery was evidently not made because it is said that prickly-pear fruit juice was collected in holes in the ground for lack of suitable containers. Water was transported by women, but no mention is made of the kind of containers used. Dried prickly pear fruits were carried in some kind of woven bag or flexible basket (sera).

The only weapon referred to is the bow and arrow, and some bows are said to have been acquired through trade with the Avavares when the Mariames were in the prickly pear collecting area. The Mariames are said to have had small shields or bucklers (rodelas) made from the hides of mature bison.

Little information is recorded on food processing and cooking. Details have already been presented and will merely be summarized here. Juice was expressed from prickly pear fruits, but the tools used are not described. Prickly pear fruits were sometimes preserved by sun-drying. Although the mortar and pestle are not specifically mentioned, various statements indicate substances that were mashed or pulverized. Roots were cooked in ovens (hornos) that are not described, but some phrases suggest a form of pit oven.

A few details on sexual division of labor among the Mariames are recorded with minimal ambiguity. Males hunted large game (deer specified), fought enemies, and old males were permitted to carry burdens. Women collected and transported firewood and water, carried most of the burdens, dug roots in winter, and processed and cooked foods. Cabeza de Vaca comments on the amount of work done by women, saying that in the winter, when roots were heavily relied on for food, they sometimes got no more than six hours of sleep at night.

Some information is recorded about the individual life cycle among the Mariames. Cabeza de Vaca, in one of his chapters summarizing behavior he had observed among the various Indians of southern Texas, states that all of them continued breast feeding of children until they were about 12 years of age. He also cites their rationalization of this practice: that it insured the health of children in a land where food was not always plentiful. The Mariames probably had a taboo against male association with menstruating women, since Cabeza de Vaca implies in a general summarizing statement that all the Indians he knew had such a taboo. He says that menstruating women could not search for or prepare foods for anyone but themselves.

Since female infanticide was the rule among the Mariames, it is evident that Mariame males obtained wives from surrounding ethnic groups, but no group names are specified in the documents. Cabeza de Vaca says that wives came from "enemy" groups. It is thus apparent that all females among the Mariames were non-Mariames. The "bride price". was said to be a good bow and two arrows or, in lieu of these, a net. It seems reasonable to assume that Mariame males 
often chose mates during the pecan and prickly pear collecting seasons, when there was maximum interaction with other Indian groups. Grounds for divorce are not indicated, although said to result from "dissatisfaction." In one of his summarizing chapters, Cabeza de Vaca states that among the groups known to him divorce did not occur if there were children. Nothing is said in the documents which suggests that males had more than one wife at the same time. Female infanticide and ethnic group exogamy indicate a patrilineal descent system among the Mariames.

In an oblique way Cabeza de Vaca refers to homosexuality among the Mariames by saying that some of them "sinned against nature." For southern Texas as a whole, he refers to pairs of males who sometimes lived together, one playing the role of female. He implies that this was observed more than once in that general area.

No data on death and burial custom are recorded for the Mariames, other than oviedo's statement that male children were sometimes killed (dream motivation) by being buried alive.

Cabeza de Vaca briefly describes a dispute between two adult males over a woman. This happened while the Mariames were in the prickly-pear collecting grounds. The only details given indicate a fight between the two men in which fists and sticks were used. After the fight, each man dismantled his house and left the encampment. Later in his account Cabeza de Vaca refers to similar disputes among various unspecified groups of the general area. Here he notes that in such cases the bow and arrow were never used. After anger subsided, the disputants returned to the encampment and forgot about the matter. However, it is also said that if the disputants were unmarried, each went to live with a neighboring Indian group for a while, sometimes a hostile one, where he was well received and was showered with gifts. The motive for such gift-giving is not stated, but some sort of reciprocal relationship is implied. Eventually the man returned to his own community. It is not certain how much of this generalized information can be attributed to the Mariames.

Little specific information on trade with other groups is recorded. It is mentioned that the Mariames sometimes obtained bows from the Avavares when both groups were in the prickly pear collecting area. A. C. Fletcher (in Hodge 1907, I:118) states that with the Avavares the Mariames also traded for bones which they "ground and used for food," but this detail does not appear in the documents. Bows, arrows, and nets were given by the Mariames to neighboring groups for wives, and occasionally a male child might be bought from a neighboring group by the Mariames, but no group name is given.

Perhaps it should be noted that Cabeza de Vaca's experience as a free-lance trader among the Indians refers to an area farther east in coastal Texas. This trading was done before Cabeza de Vaca reached the Mariames along the lower Guadalupe River. In no primary document is there any indication that Cabeza de Vaca had previously visited any Indian group west or southwest of the lower Guadalupe while trading. It appears that those who have written about Cabeza de Vaca's wide travel as a trader among Indians have not read the documents carefully enough to become aware of this negative evidence.

Cabeza de Vaca makes a few brief statements about the Mariames that are difficult to evaluate. He says that they were great liars but says nothing about lying 
in any specific behavioral context. He also states that they were great thieves, and here notes that, although they shared things with each other, things were taken from relatives (sons, fathers) when backs were turned. Just what kinds of things were taken is not stated.

Very little is recorded about warfare. It is said, as previously noted, that the Mariames regarded all surrounding groups as enemies or at least potential enemies, but only one group, the Anegados of the prickly pear area, are mentioned as having fought the Mariames and concluded a peace. Cabeza de Vaca, in two short chapters (Chapters 24 and 25), summarizes warfare for the area in Texas known to him, but this contains nothing about motivations for warfare. Some details in these chapters may pertain to the Mariames, but these cannot be confirmed by internal evidence. One defensive practice is of some interest because it may eventually be confirmed by archaeological excavation. This refers to a pit (foso) dug near an Indian encampment, when an attack was anticipated, for use as an ambuscade. The size of this pit is not indicated, but it was evidently large enough to contain a number of bowmen. The pit was covered with sticks, but openings were left for shooting arrows outward. Such pits were apparently dug mainly near encampments in wooded areas, although it is said that they were also dug at encampments on the prairies. Women and children did not sleep in the houses when an attack was expected, but in a dense part of the woods. Fires were kept burning in or near the houses to mislead the enemy.

It is evident from both Cabeza de Vaca and Oviedo that, among the Mariames, some behavior was motivated by dreams, which were a source of omens. Oviedo records a statement by Andrés Dorantes that, during the four years Dorantes was with the Mariames, 11 or 12 male children were killed or buried alive because of dream omens. Some light on this comes from Dorantes, as reported by Cabeza de Vaca, who said that Hernando de Esquivel was killed by the Mariames because a woman had dreamed that one of her sons would kill Esquivel. Méndez, another Spaniard, is also said to have been killed by the Mariames because of a dream.

No descriptive detail is recorded about ceremonies, although it is clearly stated that some behavior involved group dancing and feasting. According to Cabeza de Vaca, ceremonial activities went on despite winter food shortages and reached a peak during the summer season spent in the prickly pear area. One brief allusion to an intoxicating beverage suggests that it may have been used in a ceremonial context. This is based on a statement that the Mariames were great drunkards (grandes borrachos). Modern writers have suggested that peyote may have been involved, which is plausible, since peyote grows in southern Texas near Laredo and was widely used in later times by Indians of southern Texas and northeastern Mexico.

The equation of Cabeza de Vaca's Mariames with the Muruam recorded over 150 years later was suggested early in the present century (A. C. Fletcher, in Hodge 1907, I:805), and this equation is strengthened by documents which place the Muruam on the Guadalupe River east and northeast of San Antonio (Gómez Canedo 1968:161,244,300,306). Fletcher also suggested that the Mariames may have been the same people as the Mahuame of Mission San Juan Bautista of northeastern Coahuila. This suggestion can now be dismissed, because today it is known that Mahuame is a misreading of Chaguame, which is an orthographic variant of the name Siaguan (Cuervo y Valdéz 1701:8-9,12-14). 
Various writers have confidently equated the Mariames with the Aranamas of the Goliad mission area (Castañeda 1936, I:64; Daveriport and Wells 1918-1919:138-139; Krieger 1955:74; Newcomb 1961:49). The basis for this lay in presumed similarity in names and in the belief that both groups were associated with the same section of the Guadalupe River. Some doubt is cast upon this equation by evidence recorded in the baptismal, marriage, and burial registers of Mission San Antonio de Valero of San Antonio (Valero Registers:passim). In these registers the two groups are carefully distinguished. Between the years 1722 and 1774 at least 42 Muruam individuals can be identified, and between the years 1748 and 1762 at least eight Aranamas can be identified. A11 of the Aranamas are designated by one name variant, Jaraname; but the Muruam are recorded by such variants as Mariame, Marian, Merhuan, Moroame, Moruame, Muruame, and Muriane. This seems to indicate that the Aranamas and the Muruam at Mission San Antonio de valero represented two different ethnic groups whose names happened to be somewhat similar. Other groups names in southern Texas had similar names, such as the Pacao and the Pacoa, but missionaries did not confuse the two (Garcia 1760:title page).

Yguazes. As noted in the section on Mariames, ambiguity resulting from paragraphing changes in English translations of Cabeza de Vaca's account has led some writers to associate Mariame cultural data with the Yguazes. In the Handbook of American Indians (Hodge 1910, II:997), nearly al1 of the descriptive detait given for the Yguazes should be transferred to the entry for Mariames.

Cabeza de Vaca's statement about the distribution of Indian groups in Tower Texas indicates that the Yguazes lived inland and to the west and southwest of the Mariames, whose range, except for the summer season, can be firmly placed along the lower Guadalupe River. In terms of present-day Texas counties, the Yguazes probably occupied the greater part of Refugio County and perhaps part of southern Goliad County. Their nearest coastline neighbors were the Guaycones. Krieger (1955:63-64) places both the Mariames and Yguazes east of the Guadalupe River, but this does not agree with the evidence given by the Cabeza de Vaca and Oviedo accounts. Coopwood (1899-1900:240), who locates the Yguazes along both sides of the lower Rio Grande in extreme southern Texas and northern Tamaulipas, can be disregarded.

Two shipwreck survivors, Alonso del Castillo and Estevanico, a Black (el negro) from the Atlantic coast of Morocco, were inland with the Yguazes in 1534 and 1535 and accompanied them to the prickly pear collecting grounds each summer. Except for the seasonal migration to obtain prickly pear fruit for food and the practice of female infanticide, little can be said postively about the culture of the Yguazes. Presumably the territory of the Yguazes, like that of the Mariames, was bilobate in form, but with a somewhat shorter corridor of travel between winter and summer ranges.

In 1708 Espinosa recorded a long list of names for Indian groups which he said still lived in a general westerly direction from the missions near the Rio Grande at present Guerrero, northeastern Coahuila (Maas 1915:36-37). This would place most of these groups in what is now southern Texas. No localization of any named group is indicated. Among the names Tisted is "Oaz o Nuezes." The name Oaz is phonetically similar to Yguaz, the singular form of Yguazes. Nueces (Spanish for "nuts" but better translated as "pecans" in a southern Texas context) may be a 
Spanish synonym for the native name 0az. On this same list, the name "Moroame" also occurs, which suggests, but does not prove, that Cabeza de Vaca's Yguazes and Mariames were still known by the same names at the beginning of the eighteenth century. Although the earliest documents do not say that Yguazes collected pecan nuts in or near the Mariames' territory along the lower Guadalupe River, they do identify the Yguazes and Mariames as neighboring groups and also indicate that ethnic units from nearby areas came to the lower Guadalupe River to eat pecans (nueces) in autumn.

It is possible that the name Aguastaya, recorded in eighteenth-century records, refers to the same Indian group as the names Yguazes and Oaz. Little is known about the Aguastaya other than that, because of Apache pressures, they were among several Indian groups of southern Texas who entered Mission San José y San Miguel de Aguayo shortly after it was established at San Antonio in 1720 (Forrestal 1931:20; Haggard 1942:77; Morfi 1935:98; Rivera y Villalón 1945:111,123; Sandoval 1734:153).

The name "Jagavans," given as a separate entry in Hodge $(1907, \mathrm{I}: 628)$, appears in a context which shows that it is an extreme distortion of the name Vguazes (Harris $1705, \mathrm{I}: 802$ ).

Atayos. Cabeza de Vaca's statement on the distribution of Indian groups indicates that the territory of the Atayos adjoined that of the Yguazes, and it may be deduced from the order of name presentation that the Atayos lived inland southwest of the Yguazes. Baskett $(1907: 264)$ placed them in the general vicinity of Bee County, which appears reasonable; but we are inclined to be more specific and place the Atayos along the Mission River and some of its tributaries in the inland portion of Refugio County, perhaps extending into southern Bee County. In summer the Atayos evidently moved southwestward to the prickly pear collecting grounds, for they were seen by Cabeza de Vaca when he was among the Avavares in 1534-1535. The Atayos were said to be collecting prickly pear fruit in an area near several other groups: Avavares, Coayos, Cutalchuches, Maliacones, and Susolas. With the Susolas the Atayos were said to have been at war, shooting arrows at each other nearly every day, but how long this went on, or for what reason, is not stated.

Early speculation about the Atayos equated them with the Adai, a Caddoan group of northwestern Louisiana, and with the Toho, who lived somewhere north of Matagorda Bay in the 1680s (Hodge 1907, I:12 and 1910, II:771,1029,1030,1152; Powe11 1891:46; Smith 1851:133n and 1871:127n; Swanton 1940:136 and 1942:29). These linkages, based entirely on presumed phonetic resemblances in the names, are not demonstrable and today appear strained. Davenport and Wells (1918-1919: 230) noted the absence of the Anegados from Cabeza de Vaca's distribution roster and suggested that the name Atayos may refer to the Anegados. Nothing in the record supports this suggestion, which perhaps was motivated by a desire to make the records tidy and account for every group named.

Phonetically similar to Atayos are two Indian group names, Etayax and Ataxal, which were recorded during the years 1689-1690, over 150 years after the time of Cabeza de Vaca (Gómez Canedo 1968:160; León y otros 1961:219). These are connected with an area southwest of San Antonio, Texas, at least 140 miles from the area where Cabeza de Vaca saw the Atayos. Etayax and Ataxal are probably 
variants of a single name, but at present no evidence can be cited which links them convincingly with Cabeza de Vaca's Atayos.

The only recorded features of Atayo culture, as noted above, are seasonal migration to obtain prickly pear fruit and use of bow and arrow in warfare. They probably had a bilobate territory, but because they were nearer to the area of prickly pear concentration the corridor of travel must have been much shorter than that of the Mariames and Yguazes.

Acubadaos. The only record of the Acubadaos, also rendered as Decubadaos, is found in the Cabeza de Vaca narrative, which merely gives their location relative to some of their neighbors. Apparently none of the Spanish shipwreck survivors ever 1 ived among the Acubadaos, but probably heard of them through the Mariames or Yguazes. Cabeza de Vaca identifies the Acubadaos as an inland group that lived adjacent to the Atayos but farther inland, which would place them somewhere west of the Yguazes. It is here suggested that the Acubadaos may have lived along the upper tributaries of the Aransas and Mission Rivers in the southern half of Bee County. Since the Acubadaos are not reported as seen in that part of the prickly pear area visited by the Spaniards, it is possible that the fruit was sufficiently abundant where they lived or that they moved a short distance westward and collected fruit from an area north of where the Spaniards were, perhaps in southern Live Oak County.

Hodge (1907, I:74) equates the Acubadaos with the Arbadaos, presumably on the basis of similarity in the names, but this is untenable. As will be noted later, the recorded evidence indicates that the Acubadaos were separated from the Arabadaos by a distance of at least 100 miles.

Avavares. In the earliest edition (1542) of the Cabeza de Vaca narrative, the Avavares are also referred to by another name variant, Chavavares. Cabeza de Vaca and his three associates lived with the Avavares for approximately eight months, or from September 1534 to May or June 1535. They remained with the Avavares because winter was approaching, and they had received discouraging reports on the availability of foods southward in the direction of Panuco.

It is difficult to determine the probable range of the Avavares because there is no clear distinction between their winter and summer ranges. Such evidence as is recorded suggests that the Avavares winter range was ejther in or adjacent to their summer range in the prickly pear area and that their movements were not neatly geared to the seasons or restricted to any part of their entire range. Cabeza de Vaca's statement on relative locations of Indian groups appears to indicate where each of the named groups lived most of the year, ignoring movements by some groups to the prickly pear collecting grounds in summer. On this basis the Avavares and four other groups (Comos, Cutalchuches, Maliacones, and Susolas) may be placed inland from the coastal Quitoles in the area between Lake Corpus Christi and Copano Bay. Most of this territory 1 ies between the Aransas and Nueces Rivers, mainly in San Patricio County, but perhaps including adjacent parts of Bee and Refugio Counties, a11 of it northwest of Corpus Christi Bay. This general location seems to be supported by the fact that the Avavares lived close enough to the Mariames to learn to speak the Mariame language. How far southwestward the Avavares and their neighbors moved during the summer prickly pear season, or even during the winter, cannot be determined from the two primary documents, but as a guess, possibly as far as Benavides in east-central Duval County. 
This difficulty with locational data on the Avavares is reflected in the interpretative literature on Cabeza de Vaca's travel route in Texas. The Avavares have been assigned to various localities in a very large area that extends from the hill country north of San Antonio southward to Hidalgo and Zapata Counties near the Rio Grande, a distance of over 200 miles. Those who have placed the Avavares at least as far north as the latitude of San Antonio are Castañeda (1936, I:70-72), Sauer (1971:117), Terre11 (1962:172,176), and Wi11iams (1939:45), and those who have placed the Avavares near the Rio Grande are Coopwood (18991900:131) and Davenport and We17s (1918-1919:216). All of these placements seem to be contradicted by internal evidence in the two basic documents. The remaining route investigators place the Avavares on both sides of the lower Nueces River in parts of Duval, Jim Wells, and San Patricio Counties (Baskett 1907:264, 266, 269; Bishop 1933:107; Krieger 1961:Fig. 1; Lynn, Fox, and 0rMa17ey. 1977:Fig. 16). This placement best accommodates two recorded facts: (1) in 1535 the Avavares ranged far enough south to be fairly close to the Arbadaos, and (2) the Avavares had visited the coastal Fig People, among whom they had seen two Spanish shipwreck survivors. The Fig People, the last and southernmost coastal group to be named by Cabeza de Vaca, probably lived somewhere not far south of Corpus Christi Bay.

Cabeza de Vaca makes it clear that the language of the Avavares was different from the languages of several other groups named, among them Cutalchuches, Maliacones, and Mariames. In addition to their own language, the Avavares could speak the Tanguage of the Mariames, for the Spaniards used the Mariame language to converse with them at the first encounter.

Avavares houses are said to have been like those of the Mariames, which consisted of bent-pole framework covered by mats; and it is stated that when the Avavares moved their encampments, the houses were dismantled and transported. Since the four Europeans were divided into pairs, and each pair quartered in the house of a shaman (físico), it is possible that the houses of shamans were somewhat larger than other houses. The Avavares are said to have been collecting prickly pears near the Cutalchuches, Maliacones, and Susolas in 1535, but there is no indication that any of these populations shared the same encampment. Individuals from the three groups, however, visited the Avavares encampment, but only to ask the Spaniards to come and cure their sick individuals.

The Avavares evidently wore little or no clothing, since Cabeza de Vaca remarked that the Spaniards went about naked like these Indians. No garment of any kind is mentioned.

Cabeza de Vaca, in describing the Avavares during the winter of 1534-1535, says that the lands around them contained no fish, acorns, or nuts. With regard to fish, however, there is a discrepancy. A few sentences earlier Cabeza de Vaca refers to one of the seasons recognized by the Avavares as the time when fish die (en tiempo que muere el pescado). This may refer to spring floods which leave fish to die when floodplain pools dry up, as would occur along the lower Nueces River. Cabeza de Vaca goes on to say that, during six of the eight months spent with the Avavares, the Spaniards and their Indian hosts suffered from hunger. He notes that in winter the Avavares had an even harder time getting food than the Mariames along the lower Guadalupe River. 
Deer were hunted by the Avavares, for Cabeza de Vaca says that, for curing sick Avavares individuals, the four spaniards were given more venison than they knew what to do with. Since Cabeza de Vaca mentions that the Spaniards covered themselves at night with deer skins, it may be inferred that the Avavares did likewise.

The evidence seems to show, as noted earlier, that the Avavares lived in or near the prickly pear area throughout the year. They are referred to as searching for the fruit after other groups have left the area. In September they are reported as searching for late ripening prickly pears. On one occasion they searched five days without finding ripe fruit, and then shortly thereafter found a locality where fruit was abundant. They served prickly pear fruits as hospitality food when the Spaniards first arrived among them, and they also gave the Spaniards fruit in partial payment for curing services.

Cabeza de Vaca mentions that, on one occasion (early autumn), the Avavares had for several days searched in vain for prickly pear fruits and then went to a stream valley to gather seed pods from trees whose pods are described as like hieros ("vetches" or "lentils"). This tree has been plausibly identified as the Texas ebony, Pithecellobium flexicaule (Benth.), which holds its seed pods into the winter season. Today this tree is common along the lower Rio Grande, but rare elsewhere northward on the coastal plain as far as the latitude of Corpus Christi Bay (Corre11 and Johnston 1970:769; Turner 1959:28,30). Its seeds are edible and have at times been eaten 1ocally in southern Texas (Bourke 1931:93). Coopwood (1899-1900:129) records a fairly good stand of Texas ebony on Los 01mos Creek in southeastern Duval County, where in the 1890 s seeds were occasionally boiled for food or roasted and used as a coffee substitute by Mexican-Americans. This or some similar locality could have been visited by the Avavares.

Oviedo indicates that during winter the Avavares ate mainly roots (none described), which Cabeza de Vaca apparently confirms when he says that the Spaniards dug their own food when living with the Avavares.

The only tool recorded is a long flint knife mentioned in a legend that will be paraphrased later. The bow and arrow are specified as payment to Spaniards for curing Avavares individuals, and it is also said that Avavares traded bows to Mariames when the latter were in the prickly pear country.

The only reference to trade is Cabeza de Vaca's twice made statement that Avavares traded bows to Mariames. Presumably some special kind of wood especially suitable for making bows was available to the Avavares but not to the Mariames. No mention is made of what the Avavares received in exchange for bows. Fletcher (in Hodge 1907, I:118) states that the Avavares "bartered bones, which the Mariames ground and used for food..." This is an error, for neither Cabeza de Vaca nor Oviedo says anything about Avavares dealing in bones.

There were at least two shamans among the Avavares. Cabeza de Vaca mentioned, as noted earlier, that the four Spaniards were assigned quarters in the houses of two shamans. The Spaniards themselves "cured" Avavares of ailments vaguely referred to as disorders affecting the head and alimentary tract. Spanish treatment was the same for all Indian groups: breathing on the patient, praying, and reciting bits of church ritual. Cabeza de Vaca notes that all the sick Avavares claimed that they were completely cured by the Spaniards. Gifts or payment for Spanish 
curing, previously noted, consisted of prickly pear fruits, pieces of venison, and bows and arrows.

Brief mention is made of ceremonial activity. Just after the Spaniards had arrived among the Avavares and had treated some sick individuals, the Avavares began to dance and sing in the evening. This continued until sunrise and was repeated on the second and third nights. It is possible that this refers to a customary three-day ceremony. Cabeza de Vaca says that the Avavares and other Indian groups nearby, after being cured of their maladies, claimed the Spaniards were truly children of the sun (hijos del Sol), which suggests the concept of the sun as a deity.

While among the Avavares, the Spaniards were told a legend which Cabeza de Vaca summarizes. The action described in the legend was recounted as a relatively recent event which Cabeza de Vaca thought referred to a time some 15 or 16 years earlier, in 1519 or 1520 . It was about a man called Mala Cosa ("bad thing"), who was small of body and wore a beard. Since he had a beard and was seen only at night, his facial features had never been clearly viewed. The Avavares said that when they saw him, their head hair stood up and they shook all over. He would approach a house carrying a torch, enter, and select a man upon whom he performed two surgical operations with a flint knife said to be as wide as a human hand and about 16 inches long. In the first operation he made three large cuts in one side of the man's abdomen, reached in with his hand, and pulled out the intestines. A section of intestine about eight inches long was cut off and thrown into the fire. In the second operation Mala Cosa made three cuts at an elbow and severed the arm at this joint. Then he passed his hand over the separated parts and the arm came together again, healing instantly. Presumably the same hand passing was done over the abdominal cuts, but this is not stated.

Mala Cosa did other things. He sometimes picked up a house, took it high into the air, and then rode it down to earth. Sometimes he came to Avavares ceremonies, appearing as either a male or a female. It is said that he was offered food but never accepted any. When asked where he lived, he pointed to a crack in the earth and said that his home was underground. When the Spaniards made fun of this legend, the Avavares produced individuals who had scars on abdomen and elbow. This same legend, according to Cabeza de Vaca, had also been told the Spaniards by other unspecified Indian groups. The three operational "cuts," as well as ceremonial activity on three successive nights, suggest that in the Avavares belief system the number three had a special symbolic significance.

Cabeza de Vaca states that the Avavares paid no attention to phases and movements of moon and sun in keeping trace of time. Their main interest was in the succession of seasons, when various kinds of foodstuffs became available, and he implies that they associated seasons with the movements of certain constellations. At star gazing, he says, the Avavares were quite accomplished (diestros y ejercitados.

Anegadas. This name may be incorrect, since in the earliest known edition of Cabeza de Vaca's narrative the name is given as Ganegados (compare Núnez Cabeza de Vaca, 1542 and 1555). Smith (1871:112) introduced the variant Lanegados, which is evidentiy a misreading of Ganegados in the first edition (the initial $G$ is indistinct7y printed). Hodge $(1907, I: 57)$ noted that anegado is a Spanish word, meaning "flooded" or "overflowed," which seems to have introduced an 
irrelevance into the 1iterature. The name Anegados does not appear in Cabeza de Vaca's distribution statement, and some have suggested that it may be synonymous with Atayos (Davenport and Wells 1918-1919:230), for which no evidence seems to exist.

The Anegados are known only for a very short period in the early autumn of 1534 when they were in the prickly pear collecting grounds, and it is uncertain where they were at other times of the year. It is recorded that, while in the prickly pear area, the Anegados had been fighting with the Mariames but had just concluded a peace. It is also said that the Anegados had traded with the coastal Camoles for Spanish clothing and weapons, which the Camoles had taken from slaughtered survivors of the barge commanded by Tellez and Peñalosa, which was driven ashore in 1528. The Anegados told the Spaniards that remains of the barge could still be seen on the coast, which implies that the Anegados' winter range was immediately inland from the Camoles and that some of the Anegados had visited the shipwreck locality.

Baskett $(1907: 264,266)$ places the summer range of the Anegados near the Nueces River in southwestern San Patricio County, but the winter range he puts in the vicinity of northeastern Karnes County, for which there is no evidence in the primary documents. Surprisingly, Lynn, Fox, and 0'Malley. (1977:Table 2) assign the Anegados' winter range to a distant area lying between the lower stretches of the Brazos and Guadalupe Rivers, for which no evidence is adduced. Perhaps the best that can be done, since Cabeza de Vaca left the Anegados off of his distribution roster, is to suggest that their trading relationship with the Camoles points to a winter residence somewhere in southern Nueces County, which is not very far east of the area of prickly pear concentration where they were encountered by Spaniards.

Cutalchuches. This name is now known by at least 18 orthographic variants, most of them occurring in translations of the Cabeza de Vaca narrative into various European languages. In the earliest Spanish edition (1542), the name is rendered in two ways, as Cuthalchuches and Cultalchuches, which may be closer to native phonemes than Cutalchich, the variant chosen for use by Hodge $(1907,1: 374)$.

Cabeza de Vaca briefly encountered the Cutalchuches in the summer of 1535 . They were in the prickly pear collecting grounds and were eating fruit in the same locality as the Avavares, Maliacones, Coayos, Atayos, and Susolas; and the encampments of at least some of these groups were close enough to each other for individuals to visit back and forth. It is clear that the cutalchuches' winter range was elsewhere because Cabeza de Vaca wrote that, shortly after his encounter with the Cutalchuches, they returned to their own country (1ocation unspecified). It seems evident that their country was not southward in the direction of Pánuco, the Spaniards' planned destination at the time. Cabeza de Vaca's statement on Indian group distributions, however, places all these Indian groups except the Atayos inland from the coastal group known as Quitoles, who seem to have occupied the Ingleside-Aransas Pass-Rockport section of the coastline. This suggests that the Cutalchuches' winter range was in or near the area covered by northwestern Nueces County and southwestern San Patricio County. This is not incompatible with Krieger's (1967:Fig. 1, No. 3) placement of the summer range of the Cutalchuches and their neighbors in the northern portions of Duval and Jim Wells Counties. Baskett (1907:264) places the 
Cutalchuches' summer range farther north, in central Live Oak County, just below the junction of the Frio and Nueces Rivers.

Although Cabeza de Vaca is not entirely clear about the language spoken by the Cutalchuches, it seems to have been different from the languages spoken by the Avavares and Maliacones, which at least points to linguistic diversity among the Indians who went to the prickly pear collecting area.

Relatively little is recorded about the culture of the Cutalchuches. They of course ate prickly pear fruit in season. Cabeza de Vaca mentions that, at the end of the pear season, they gave the Spaniards all the ripe pears they had on hand, not keeping a single one. At the same time the Cutalchuches also gave the Spaniards something else to which they (the Cutalchuches) attached great value, large flint knives. The number of knives is not indicated, but one knife may have been given to each of the four Spaniards. These knives had a length of about 12 inches (palmo $y$ medio; a palmo at that time was equivalent to 8.23 inches, according to Haggard 1941:81). It is possible that these large flint knives were valued by the Cutalchuches because of some ceremonial use.

It has been speculated that the Cutalchuches were the same as the Guachichil of north-central Mexico (Ruecking 1955:275-276) or may have been a Tonkawan group (Mayha11 1965:251). No evidence has been found which supports either of these speculations.

Maliacones. Cabeza de Vaca met the Maliacones (or Malicones) shortly after Teaving the Avavares in 1535. The four Spaniards, apparently traveling southsouthwestward in the general direction of Pánuco, went on to an encampment of the Maliacones. This involved one day of travel, the distance said to be seven leagues, or about 18 miles. With these Maliacones the Spaniards then traveled on in the same direction (distance not given) to an Arbadaos encampment, and the Maliacones then returned to their previously mentioned camp. This at least places the Maliacones on one occasion roughly south of the Avavares and north of the Arbadaos, possibly in the general vicinity of San Diego and Alice of Duval and Jim Wells Counties respectively. But Cabeza de Vaca's Indian group distribution statement, which seems to reflect winter ranges, places the Maliacones among the groups that 1 ived inland from the Quitoles, or somewhere near the lower Nueces River.

Krieger (1961:Fig. 1) apparently considered the Maliacones to have been native to the lower Nueces area, but Baskett (1907:264) puts them farther north, in central Live Oak County. It is difficult to understand Covey's (1961:91) unexplained placement of the Maliacones on the lower Colorado River, some 125 miles northeast of the lower Nueces River and the nearby prickly pear area.

Cabeza de Vaca indicates, as noted above, that the Maliacones, Avavares, and Cutalchuches spoke different 1anguages. The Maliacones ate prickly pear fruits in the collecting area, as well as seeds from certain trees found farther south, which it is said they ate for 10 or 12 days while waiting for prickly pears to ripen in early summer. These seeds may be those of the Texas ebony (see Avavares). 
Coopwood (1899-1900:136) and Newcomb (1961:60) suggest that Cabeza de Vaca's Maliacones may have been the Malaguitas or Malaguecos of the lower Rio Grande, known from the middle eighteenth century. This is possible, but there is nothing which relates the two sets of people except some similarity in names and location in areas not greatly distant from each other. Hodge (1907, I:795, $800,845)$ suggests that Cabeza de Vaca's Maliacones may have been the same as the Meracouman of Joutel and the Manico of Mazanet. The Meracouman Tinkage does not seem reasonable, since the 1687 Joutel reported Meracouman northeast of Matagorda Bay (Stiles 1906:126). The Manico linkage is somewhat more plausible because in 1690 Mazanet reported Manico in what is now Frio County (Gómez Canedo 1968:160), or about 100 mi les northwest of where Cabeza de Vaca's Maliacones are believed to have been seen. In 1708 Espinosa reported "Manicu" as still 1iving somewhere in what is now southern Texas (Maas 1915:36-37). These data have suggestive value but do not actually demonstrate that the names Maliacones and Manico refer to the same Indian population.

Susalas. These were seen by Cabeza de Vaca in 1534-1535 when he was living * among the Avavares. His account is somewhat ambiguous about their territorial range. In giving the relative locations of Indian groups, he places the Susolas in the vicinity of the Avavares, Comos, Cutalchuches, and Maliacones, whose winter locations seem to have been near the lower Nueces River. Elsewhere he notes that the Susolas were near the Atayos and Coayos in the prickTy pear collecting area. In still another place, he mentions that he had first encountered the Susolas when he was living with the Mariames on the lower Guadalupe River. There he had treated some of them for 117 ness and had been paid in pecans and animal skins. Thus, of a11 the groups said to have converged on the Guadalupe River to collect pecans in the autumn, only the Susolas are noted by name. Students of Cabeza de Vaca's travel route in Texas have shown little interest in locating the Susolas, and only Coopwood (1899-1900:132) and Castañeda (1936, $I: 72)$ noted the reference to Susolas on the Guadalupe River. Possibly the best that can be done with the Susolas is to place their principal range on the lower Nueces River, from which they went westward or southwestward for prickly pear fruit in the summer and northeastward to the lower Guadalupe River for pecans in the fall.

A few descriptive details on the Susolas culture are recorded. Houses are mentioned but not described. It is said that when a death occurred in a house it was immediately torn down. Hunting may be inferred from the bow and arrow and the reference to animal skins. Prickly pear fruit was eaten in ripened form, and mention is also made of prickly pear fruit that had been pounded, presumably after being dried. Prickly pear fruit was given to the Spaniards in payment for curing services. The Susolas also ate pecans, but only when they were foraging in the lower Guadalupe River area, as noted above.

The bow and arrow are referred to in two contexts: warfare and payment for Spanish medical treatment. Matting was made but only one use is recorded, as a shroud for corpses. Baskets were also made, three such containers being mentioned as holding prickly pear fruit.

Hostilities between the Susolas and Atayos are mentioned. No reason for fighting is stated, but it is said that the two peoples were exchanging shots daily when the Spaniards were in the prickly pear area. The only life cycle data recorded have to do with death. A dead person was covered with a mat, his 
house torn down, and relatives wept. The only curing practices recorded refer to Spaniards treating sick persons among the Susolas. When Cabeza de Vaca was among the Avavares, some of the Susolas came to the Avavares encampment and asked him to treat a wounded man and a number of sick individuals, one of whom was said to be at the point of death. Cabeza de Vaca goes into considerable detail about the man who was said to be dying. He found this man apparently already dead; he was covered with a mat, and his house had been torn down. Cabeza de Vaca could detect no pulse but went ahead with his curing routine. Later he was told that the "dead" man had recovered.

Hodge $(1907, I: 511)$ has suggested that the Susolas may have been the same as the Gueiquesales and Guisoles reported in northeastern Coahuila and the adjoining part of Texas in the late seventeenth century. It is now known that the names Gueiquesales and Guisoles are variants of the same group name, but it is grasping at phonetic straws to relate Cabeza de Vaca's Susolas to the Gueiquesales, whose rather wel1-recorded range was some 250 miles farther west and northwest (Bolton 1916:285,299,301-308; Figueroa Torres 1963:58,69,89,103-119; Steck 1932:6-7,9-13, $19-21,24-26)$.

Comos. This name appears only in Cabeza de Vaca's group distribution statement, in which the Comos are said to be closely associated with Avavares, Maliacones, Cutalchuches, and Susolas, and this is the basis here for assigning the Comos to an area near the lower Nueces River northwest of Corpus Christi Bay. Baskett (1907:264) places the Comos just south of the junction of the San Antonio and Medina Rivers, or not far south of the city of San Antonio. This seems unreasonable, as does the placement by Lynn, Fox, and 0'Malley (1977:Table 2) near the coast between the Brazos and Guadalupe Rivers. The pertinent data in the Spanish records rather clearly indicate a location not very far inland but west, not east of the Guadalupe River.

The Comos are sometimes equated with the Coayos (Baskett 1907:264n; Davenport and We11s 1918-1919:221,231) because each name is given by Cabeza de Vaca in a context which closely associates it with Cutalchuches, Maliacones, and Susolas. This has suggestive value, but does not constitute proof. Davenport and Wells (ibid.) say that the names Comos and Coayos probably refer to the same population and that this population may be identical with either the Como se Llamas or the Comecrudos reported in the middle eighteenth century as living along both sides of the lower Rio Grande in southern Texas and northern Tamaulipas. These suggested 1inkages, which are based entirely on similarity in names, now seem farfetched.

If the Comos can be related to any group recorded in later times, a somewhat better case can be made for the group known as Arcahomos, first recorded in 1737 at one of the San Antonio missions. The Arcahomos were said to be closely associated with the Tacames, who, in the first half of the eighteenth century, were occupying an inland area lying between the lower sections of the San Antonio and Nueces Rivers (Bolton, in Hodge 1910, II:435-436,666-667). This would put the Arcahomos close to the presumed Comos territory. The difficulty is that by this late date the Arcahomos, a very poorly documented group, could have been displaced from some other area.

Coayos. The Coayos are not named in Cabeza de Vaca's statement of group distribution, but they are mentioned elsewhere as collecting prickly pear fruit in the 
summer of 1535 close to four other groups: Atayos, Cutalchuches, Maliacones, and Susolas. Thus there is no evidence of where the Coayos lived during other seasons, unless it is assumed that by a slip of memory Cabeza de Vaca recorded the Comos as Coayos (see comos for brief discussion).

Later records (1689-1707) contain three names that have varying degrees of similarity to Coayos. These are Cauya, Coaxa, and Cuajin, a11 associated with areas farther west, and each is so poorly recorded that it is not possible to demonstrate any relationship to Cabeza de Vaca's Coayos (Gómez Canedo 1968:160; León y otros 1961:219; San Francisco Solano Baptisms, No. 288).

Comment. Three Rivers and the nearby Choke Canyon Reservoir are approximately 85 miles from the nearest portion of the outer shoreline of the Gulf of Mexico. According to the interpretation of the Cabeza de Vaca route used here, at least 11 of his named groups ranged over Area 2, which lies between Three Rivers and the Gulf Coast. It is believed that Cabeza de Vaca's general line of travel from the lower Guadalupe River to the prickly pear area passed within 50 miles of Three Rivers. One group, the Acubadaos, may have ranged within 30 miles of Three Rivers. The center of the prickly pear collecting grounds was probably about 50 miles south-southeast of Three Rivers.

The 11 groups of Area 2 appear to have ranged over an inland area of some 5000 square miles. This area extended from the valley of the lower Guadalupe River southwestward perhaps as far as Santa Gertrudis Creek, an intermittent stream that flows into Baffin Bay. The maximum length of Area 2 was at least 110 miles, and its greatest width probably did not exceed 75 miles. This area included the inland parts of present-day Aransas, Nueces, Refugio, and San Patricio Counties and parts of Bee, Calhoun, Duval, Goliad, Jim Wells, Kleberg, Live Oak, and Victoria Counties.

The Cabeza de Vaca narrative seems to indicate that Area 2 was not characterized by linguistic uniformity. It is not possible, however, to determine the nature of the linguistic units represented. Several dialects of one language may have been spoken; or dialects of two or more languages, either related or unrelated, may have been spoken; or each group may have spoken a language unrelated to any of the others.

In the latter part of his narrative, Cabeza de Vaca (see Hodge 1953:107) mentions. that the four Spanish survivors had learned to speak six different "languages" during their six to seven years in the lower part of Texas. He does not identify the groups whose languages were learned, but it may be inferred from the length of time the Spaniards spent with various Indian groups that the six languages were probably those spoken by Capoques, Chorrucos, Quevenes, Mariames, Yguazes, and Avavares. Of these, only the last three can be placed in Area 2.

Only three native Indian words are recorded by Cabeza de Vaca, and not one of these is linked with the name of a specific ethnic group. Cabeza de Vaca does say in various passages, however, that two or more groups spoke either the same language or different languages. The Avavares, Cutalchuches, and Maliacones apparentiy spoke different languages. The Avavares are said to have spoken their own language, as well as that of the Mariames. It is thus possible to claim that at least four different dialects or languages are obliquely reported by Cabeza de Vaca for Area 2: Mariames, Avavares, Cutalchuches, and Maliacones. Beyond this, 
all statements about dialects or languages and their broader affiliations must remain speculative.

It has been customary for nearly a century to relate the languages of some of Cabeza de Vaca's more westerly Indian groups to several languages for which samples were collected long after the time of Cabeza de Vaca, particularly Karankawa, Tonkawa, and Coahuilteco. This is often done without due regard for the fact that the recorded language samples obviously do not represent al1 the languages once spoken in the general area. It can be argued, with some degree of plausibility, that the Quevenes may have spoken a dialect of the language now known as Karankawa, but it is much more difficult to argue that the Mariames spoke a dialect of Tonkawa or that other groups spoke dialects of Coahuilteco. This speculative categorizing should be accompanied by clear statements about the assumptions made and about the tenuous nature of the Tinguistic evidence in each case.

As the cultures of the various groups are so uneveniy described, it is difficult to determine just how many cultural features were probably shared. If the languages varied considerably, there may have been a corresponding variation in other aspects of the cultures. Most of the recorded cultural information pertains to Avavares and Mariames, whose ranges except in summer seem to have been at opposite ends of Area 2. These two groups did share a number of cultural characteristics. Groups ranging between the Avavares and Mariames may also have shared some of the same characteristics.

It is fairly clear that al1 groups of Area 2 were hunters and gatherers, and enough evidence is available to suggest rather strongly that they shared a distinctive foraging pattern. These inland peoples relied heavily on the use of two foodstuffs, pecan nuts and prickly pear fruits, that were naturally produced in considerable quantities but became edible at different times. The main sources of these two foodstuffs were separated by a considerable distance, requiring travel in early summer (for fruits) and in autumn (for nuts). At other times of the year foods consisted of whatever was available in the traditional territories. This particular pattern does not seem to be indicated for other groups encountered by Cabeza de Vaca.

For one group, the Mariames, there is sufficient recorded information to give an impression of the size and shape of their total foraging territory for a single year. The Mariames ranged over two rather widely separated areas that were joined by a narrow corridor of travel. If plotted on a map, this territory may be described as bilobate. The maximum distance between the outer ends of the lobes may have been as great as 110 miles. Cabeza de Vaca shows that the Yguazes had a similar foraging range, and other groups west and southwest of the Mariames and Yguazes must have had similar ranges but with shorter corridors of travel between lobes.

The documents provide no estimates of total population size for any Indian group of Area 2. Bits of quantitative data recorded for the Mariames suggest that this group may have consisted of no more than 200 individuals during Cabeza de Vaca's time. In the documents there is no reference to any group being notably larger or smaller than another group. It is clear that the settlements of all groups were temporary and were moved when foods available in a locality became scarce, or when important foods became seasonably available in restricted areas elsewhere. No group of Area 2 is mentioned as living in two or more settlements at 
the same time. The limited information on houses indicates only one type, a circular, dome-shaped structure with bent-pole framework covered by mats. When an encampment was moved, houses were dismantled and carried to the new location. As this type of house is recorded for Avavares and Mariames, it was probably also used by the nine other groups of this area.

The only large game animals mentioned are deer and bison. Deer were hunted in several ways: one hunter overtaking a single animal by running until it became exhausted; burning of dry grasses to localize herds of deer; and communal driving of deer into saltwater.

In his narrative Cabeza de Vaca states that he had seen bison only three times, but he never says where he was when he saw them. Apparently he saw some bison when he was living with the Mariames, for he briefly describes bison at the end of his section on the Mariames. Yet he never indicates that he actually saw Mariames hunting bison. He next refers to bison after he and his companions had crossed into what is now northeastern Mexico and had reached northern Coahuila, but he does not mention seeing bison hunts there. He merely refers to bison hides and their uses. It thus appears that Cabeza de Vaca's route across North America skirted the southern edge of the bison range at that time.

It is puzzling to note that Cabeza de Vaca never refers to rabbits and rabbit hunting among the Indian groups of southern Texas. Rabbit hunts are mentioned only when he describes Indian groups of Coahuila. Other small animals, such as rats and mice, frogs, snakes, as well as certain insects, mentioned for the Mariames, were probably eaten at times by all the groups of Area 2 .

The use of fish for food among these inland groups must have been minimal, the documents seeming to indicate only the use of fish that were collected from overflow pools of river floodplains during rainy seasons. There is no indication that any of these groups went to the Gulf Coast for saltwater fish or shellfish, and no specific mention of bartering with coastline groups for these sea foods. It thus appears that in Cabeza de Vaca's time there was notable contrast in subsistence patterns between inland and coastal populations.

It is sometimes assumed that, while in the prickly pear collecting area in summer, the Indians ate nothing but prickly pear fruit for several months. "This reflects careless or selective reading of the documents. The oviedo account indicates that snails were collected and eaten in quantity, and the Cabeza de Vaca narrative states that while in the prickly pear area the Spaniards sometimes received venison as payment for curing services.

The size and density of prickly pear stands may have been increased by Indian harvesting activity. If prickly pear thickets were as dense as those described in nineteenth century sources, it must sometimes have been necessary for Indian individuals to take sticks and beat out passages into the thickets to get additional fruit. Any prickly pear internode that lies on the ground can develop roots and begin upward growth. It is less 1ikely that prickly pear plants were spread by means of fruit seeds that passed unaltered through the human alimentary tract. Birds would undoubtedly find, consume, and digest most of these voided seeds.

It is sometimes assumed (for example, see Kelley 1952:142-143) that Cabeza de Vaca's prickly pear area was unique, and that it was visited during summer by Indian groups 
who came to it from all directions. Internal evidence in the documents lends no support to this assumption. It is not possible to link any of Cabeza de Vaca's prickly pear fruit collectors with areas to the northwest, west, southwest, or south of the collecting area described. The Arbadoas and Cuchendados, who lived near the Rio Grande (Area 3), are not identified by Cabeza de Vaca as being in his prickly pear collecting area. What is really unique about Cabeza de Vaca's prickly pear area is that it was located on the northeastern edge of a large region in southern Texas and northeastern Mexico where there were many localized concentrations of the plant. Such evidence as is recorded in the two basic documents indicates that Indian groups came to Cabeza de Vaca's prickly pear collecting area from a specific nearby area, located mainly between the lower Guadalupe and lower Nueces Rivers, where the prickly pear plant did grow but not in great profusion. The summer trek to the prickly pear area was part of a special inland subsistence pattern that involved making full use of such foodstuffs as were seasonally abundant. These Indian groups were close enough to a large area of prickly pear concentration to walk to it and live in it as long as the fruit was still ripening in quantity. It is of interest to note that the only kind of food preservation mentioned is drying of prickly pear fruits, and this dried fruit was used only during seasonal travel away from the collecting grounds.

Only the Mariames and Susolas can be firmly connected with pecan harvesting along the lower Guadalupe River, but there is some evidence which suggests that the Yguazes also went there for nuts. As the Oviedo account mentions that Indian groups came to gather pecans along the Guadalupe River from distances of 20 to 30 leagues (52 to 78 miles), it is probable that most of the groups of Area 2 participated in the pecan harvest when there was a good crop.

The collection of pecans is basically not very different from the collection of prickly pear fruit in this area. There was a localized seasonal abundance of both foodstuffs, and Indians nearest to the sources of supply moved in to exploit each kind of food as long as it lasted. If any other kind of foodstuff had been available in quantity, the Indians would also have exploited it in the same way. Seasonal migration to collect pecans and prickly pear fruit may have great time depth in Area 2, and specialists in the archaeology of that area may eventually find it reflected in the distributions of distinctive styles of prehistoric artifacts.

Roots of unspecified plants are said to have been critical in the winter diet of the Mariames and are also reported as eaten in winter by the Avavares. Roots of various kinds were probably important winter foods among other groups of Area 2 . The Mariame data link root baking with some kind of earth or pit oven, traces of which may eventually be found by archaeologists. It would be of much interest to discover what plants of the lower Guadalupe River area produce roots or tubers that are nontoxic and nutritious after being baked.

Dietary deficiencies may partially explain the eating of pulverized bone, earth, wood, and deer droppings by the Mariames.

Very little is recorded about clothing and ornaments of the Indian groups of Area 2 . Apparently very little or no clothing was worn except in cold weather, skin robes and moccasins being mentioned for the Mariames. Undescribed ornaments were inserted in the perforated lips and nipples of Mariame males.

Information on handicrafts and the resulting artifacts is minimal. It seems clear, however, that bows and arrows were made and in universal use. No pottery was 
manufactured, but baskets or bags were made and used for containers. Nets and mats were produced, and the mortar and pestle may be inferred from statements about Mariame food preparation.

No group in Area 2 is reported as being in any way dominant over another group, nor is any group referred to as a subdivision of another. If there was a tribal organization anywhere in Area 2 during Cabeza de Vaca's time, it is not reflected by such data as have been recorded. Political leaders of any kind are not mentioned. The basic sociopolitical unit may be thought of as the band, although the descriptive information is so meager that a more neutral term, "group, "has been used in this study. Hostilities between groups are occasionally referred to, but little is said about motivation or behavior when fighting.

It may be inferred that certain kinds of customary behavior were present and possibly widespread in Area 2. Among these are group exogamy, female infanticide, the menstrual taboo, and prohibition of sexual intercourse between man and wife for two years after the birth of a child.

Shamans were probably universal in this area, although their behavior is never described. Presumably the shaman's main function was curing illness. It may be inferred from the curing activities of Spaniards that shamans were paid or at least received gifts when patients were treated.

Such ritual and cermonial activity as is mentioned involved dancing and feasting. The Avavares appear to have had at least one three-day ceremony. One passage implies that the sun was regarded as a deity. One legend recorded for the Avavares, and mentioned as known to other groups, involves a supernatural figure who performed surgical operations.

Very little is said about intergroup trade or barter in Area 2. Bows were involved in trade between Mariames and Avavares, and it may be inferred that some groups of Area 2 obtained Spanish clothing and weapons in trade from coastline groups of Area 1 .

Cabeza de Vaca's experience as a traveling, freelance trader among the Texas Indians has been greatly exaggerated. This trading occurred while he was living among the Chorruco east of the lower Brazos River. The brief account of his trading activities does not give the name of a single Indian group with whom he traded when away from his Chorruco base. He says that he went into the interior as far as he chose, but he specifies no distances. He also says that he traveled along the coast 40 or 50 leagues (up to 130 miles), but no directions are indicated. He does not describe any terrain he traversed or refer to the cultural characteristics of any Indians with whom he dealt. Later in his narrative, after telling about his moving westward along the coast of the Mariames, he says nothing about having previously traded with Mariames or any Indian group farther west or southwest. Thus the record fails to support those who have assumed that Cabeza de Vaca had traded as far west as the prickly pear collecting grounds and beyond, or as far north as the agricultural Caddoan groups of eastern Texas.

Most of the Indian groups of Area 2 have at times been referred to as "Coahuiltecans." Originally this name was used to refer only to certain groups that were believed to have spoken the language now known as Coahuilteco. In recent years the name Coahuiltecan has come to be rather loosely used to refer to nearly 
a11 of the hunting and gathering groups of southern Texas and northeastern Mexico, who are assumed to have had similar cultures. The widespread similarities in culture have never been demonstrated. As now commonly used, the name Coahuiltecan has about the same connotation as the name Chichimec, which in Mexico has long been used to refer to any hunting and gathering group north of the Valley of Mexico. It serves no useful purpose to refer to the Indian groups of Area 2 as Coahuiltecans.

Failure to analyze the documents and structure the information on geographic location and culture for each Indian group has all too often led to unrealistic overgeneralizing about Cabeza de Vaca's Texas Indians. The following statement, selected because it is an extreme example, overgeneralizes to the point of absurdity:

It was the adventurer's misfortune to be thrown among destitute nomadic Indians who were always on the edge of starvation. They had no agriculture of their own, but lived on fish, oysters and the roots of water plants, except in the autumn when they went inland to gorge themselves on prickly pear, walnuts and pinenuts. They got an occasional deer by infinite labour... his little company of four broke away from the feast of the prickly pears somewhere between the Sabine and Trinity rivers . . . (Brebner 1933:72-73).

This shows what can happen when the time and place contexts of specific bits of information from the Cabeza de Vaca documents are ignored. The various hunting and gathering groups distributed along the Texas coastal plain from just east of the Brazos River to the Rio Grande, and then westward as far as northern Coahuila, are made to appear very much alike, all subsisting on the same foods. The statement is made without any evident awareness of the various environmental units involved. Cabeza de Vaca carefully distinguishes between shoreline and inland groups, and no shoreline group is said to have gone inland for prickly pear fruit, and certainly not between the Sabine and Trinity Rivers in humid southeastern Texas. "Pine-nuts" (piñon) were not available in Cabeza de Vaca's time and are not available today anywhere on the Texas coastal plain, but are common in mountainous northern Coahuila. The "occasional deer" taken by "infinite labour" is not compatible with Oviedo's mention of a single deer hunt that yielded 500 animals.

Area 3

In Area 3, near the lower Rio Grande, Cabeza de Vaca encountered only two Indian groups, the Arbadaos and the Cuchendados. They appear to have lived northeast of Falcón Lake, either in or very near present-day Jim Hogg County. It is clear that these two groups were not seen by Cabeza de Vaca in his prickly pear area. They had prickly pear concentrations in their own area, and there was no need for them to travel to the lower Nueces River for fruit. It was after leaving the Cuchendados that the Rio Grande was crossed, and shortly thereafter the Spaniards saw their first mountains in what is now northern Nuevo Leon. 
Arbadaos. Cabeza de Vaca indicates that in the late spring or early summer of 1535 he and his associates traveled with the Maliacones for one day and came to a settlement of the Arbadaos, the distance traveled being recorded as seven leagues, or about 18 miles. The direction was evidently southwestward, since the Oviedo account states that the Arbadaos were first seen some 17 to 20 leagues (44 to 52 miles) from the river that is identifiable as the Rio Grande. Negative evidence seems to indicate that Cabeza de Vaca and his men passed west of the Sand Plain that extends from the Gulf Coast westward into eastern Jim Hogg County, and the most plausible location for the Arbadaos is an area that centers in northwestern Jim Hogg County, or in the general vicinity of present Hebronville. According to the documents, the Arbadaos were seen in an area where water was scarce and where dense thorny vegetation is described, apparently along intermittent stream courses. The Spaniards spent eight days with the Arbadaos.

It seems important to note that the Arbadaos were encountered more or less southwest of Cabeza de Vaca's prickly pear concentration and that the Arbadaos are not mentioned as gathering fruit there, apparently because they had access to enough prickly pear thickets in their own area. No Indian groups beyond the Maliacones, that is, to the south and southwest, are identified as going northward for prickly pear fruit.

Hodge (1097, I:74) equates the Arbadaos with the Acubadaos, probably because the name Arbadaos does not appear on Cabeza de Vaca's group distribution list; but this is not acceptable because internal evidence in the documents indicates that the Arbadaos and Acubadaos were separated by a distance of at least 100 miles. Placement of the Arbadaos near San Marcos, Texas, by Castañeda (1936,I:73) and by Terrel1 (1962:182) is untenable because, in addition to difficulties with the direction of travel, the water resources and vegetation of the San Marcos area do not agree with the Spanish descriptions. Lynn, Fox, and 0'Malley (1977:Fig. 6) place the Arbadaos on the Rio Grande in the vicinity of Falcon Lake, which is too far south for Oviedo's citations of the distances traveled.

The language spoken by the Arbadaos is said to have been the same as that spoken by the Cuchendados, the next group encountered after leaving the Arbadaos. Some cultural detail is recorded for the Arbadaos. House form is not described, but it is stated that houses were covered by mats. It is implied that these mats were transported when a settlement was moved. The Arbadaos had dogs, two of which the Spaniards bartered for and ate, but it is not stated that dogs were eaten by the natives. At the time of Cabeza de Vaca's visit the Arbadaos were suffering from hunger, and practically all their waking hours were spent in the search for something to eat. Foods mentioned include meat of unspecified animals; prickly pear pads and fruit (the latter eaten both green and ripe); and two kinds of seeds, one of which may have been from the Texas ebony. Cooking methods include broiling (meat) and baking (green prickly pear fruits and stem pads apparently baked in some sort of pit oven). Bows and arrows are mentioned, as well as nets (uses unspecified). Hides were processed by scraping (tools not described). Combs are also mentioned, but these were made by Cabeza de Vaca and traded to the Arbadaos. 
Newcomb (1961:60) has suggested that, because of similarities in the names, the Arbadaos may be the same people as the Borrados later recorded in Nuevo León. This does not appear to be reasonable, since Arbadaos is an Indian name and Borrados a Spanish name. Any resemblances in the names are evidently fortuitous.

Cuchendados. This name does not appear in a descriptive context in Cabeza de Vaca's narrative and is merely mentioned as the name of a group which seems to have been the last one encountered in what is now southern Texas. The name may not be correctly applied, but it has often been interpreted as referring to a nameless group with which Cabeza de Vaca and his men spent about 15 days in the late spring or early summer of 1535 . It is clear enough from the Oviedo account that these people were first seen at least 20 to 25 miles north of the river that is identifiable as the Rio Grande. They lived about the same distance from the Arbadaos. Their settlements are described as being in wooded localities, evidently along tributaries of the Rio Grande, and there is no mention of water shortage.

Hodge (1907, I:370) implies that the Cuchendados lived on the Gulf Coast, but no evidence supports this. Lynn, Fox, and O'Malley (1977:Fig. 16) place the Cuchendados on both sides of the Rio Grande in the vicinity of Falcón Lake. Since the recorded travel distance indicates a location about 25 miles from the river, it is possible to be more precise and assign the Cuchendados to an area in or near southwestern Jim Hogg County.

Some cultural detail is recorded for the Cuchendados. The language spoken is said to have been the same as that spoken by the Arbadaos. Houses are not described, but two settlements are mentioned, one consisting of two or three houses (ranchos), the other of 40 to 50 houses. This is the first reference in Cabeza de Vaca's narrative to any group of southern Texas having been seen in more than one settlement at the same time. Foods mentioned include meat (animals unspecified) and prickly pear stem pads and fruits, the latter eaten both green and ripe. Green prickly pear foods were baked in some kind of pit oven.

It is among these people that Cabeza de Vaca first describes use of the mesquite bean pod (mezquiquez) for food, but its use is rather clearly indicated as part of a ceremony, or at least a special social occasion. The seed pods (green? dry?) were placed in a hole in the ground (dimensions not stated) and pounded with a wooden pestle over five feet long and said to have the diameter of a human leg. This pounding was done by an adult male, not an adult female as might be expected if the operation was routine food preparation. In addition to earth that fell from the walls of the pit, handfuls of earth were added from time to time by the man who did the pounding. The mixture of pod flour and earth was taken from the hole and put into a container said to be like a two-handled basket (espuerta). Enough water was then added to cover the materials, and additional earth was added after repeated tasting. Then people sat around the container and scooped out paste with their hands, spitting out the hard-cased seeds and 
other unpulverized bits, which were put on an animal skin. Later these expectorated materials were returned to the empty container and water added. The procedure was repeated three or four times. Cabeza de Vaca referred to the occasion as a "banquet" that continued intermittently as long as the Spaniards were among these people. He also added that those who ate this food ended up with distended abdomens. Newcomb (1961:42-43) attributes this use of mesquite to the Arbadaos instead of the Cuchendados.

The Spaniards were asked to cure sick persons and to place their hands on children. Cabeza de Vaca noted that the Cuchendados were the first people encountered along his route who regarded Spaniards with such awe that food was given to them even when it meant that the Indians themselves had nothing to eat.

Comment. Although Cabeza de Vaca and his companions passed rapidiy through Area 3, the documents yield considerable information on the two groups encountered. Area 3 is of special interest because its two Indian groups are said to have spoken the same language, which apparently did not duplicate any language previously noted by Cabeza de Vaca. These Indians must have had access to the local concentrations of prickly pear reported by Davenport's nineteenth-century observers. Here the mesquite bean is first reported as being used for food, which suggests that this plant was not common farther north during Cabeza de Vaca's time.

Settlements in Area 3 seem to have been somewhat larger than those of Area 2, and the Cuchendados are reported as living in at least two settlements at the same time. Certain cultural features, however, seem to be no different from those of Area 2, such as manufacture of basketry, use of some kind of pit oven, and possibiy the house type, since houses are described as being covered with mats.

\section{INDIANS KNOWN AFTER THE TIME OF CABEZA DE VACA}

As noted earlier, it is some 150 years after the time of Cabeza de Vaca that written documents again refer to specific Indian groups in southern Texas. Most of the Indian groups that can be Tinked with the Three Rivers target area are known primarily from documents that pertain to Spanish missions of northeastern Coahuila and southern Texas, particularly those of San Antonio and more particularly the last three missions that were established at San Antonio.

In 1731 three missions were moved from eastern Texas and reestablished, with some alteration of names, at San Antonio. These were Nuestra Señora de la Purísima Concepción de Acuña, San Francisco de la Espada, and San Juan Capistrano. Missions San Antonio de Valero and San José y San Miguel de Aguayo had already been established at San Antonio in 1718 and 1720 respectively. By 1731 Apaches were seriously disrupting the hunting and gathering populations of southern Texas, and many of the Indian groups initially represented at these last three San Antonio missions seem to have come from the more easterly portion of southern Texas, that is, near the Gulf Coast. Unfortunately, the registers of these new missions, except for 
the marriage register of Concepción, have not been found, and other documents are not particularly informative about the Indian groups involved, particularly their territories at the time, the languages they spoke, and how they differed from one another culturally. It seems clear enough, however, that the three missions established at San Antonio in 1731 received remnants of Indian populations that lived to the east of the major source areas of Indians who entered Missions San Antonio de Valero and San José.

\section{Groups Native to the Area}

In this section information is presented on 17 Indian groups that can be 1 inked with the Three Rivers target area. Information on the Apaches, who were immigrants, is presented in a second section. The native groups are arranged in alphabetic order.

Arcahomo. Bolton (in Hodge, 1910, II:435,666) identifies Arcahomo as an alternative name for the Tacame, but he fails to cite a document which contains supportive evidence. The few documents which refer to the Arcahomo seem to recognize them as forming as separate and distinct ethnic unit. About a11 that is known of them is that in 1737 some Pacao and Arcahomo fled together from Mission San Francisco de la Espada. The records do not specify direction or distance traveled, but they may have gone to traditional territories somewhere southeast of San Antonio. Shortly afterward, 108 of the Pacao and Arcahomo fugitives were persuaded to return to Mission Espada (Castañeda 1938, III:68-69; Orobio y Bazterra 1737:44-45; Ysasmende 1737:41-42). It is possible that the "Acomas" referred to in documents pertaining to secularization of missions near present Goliad in 1829 were the same people as the Arcahomo of Mission Espada at San Antonio (Walters 1951:293,298).

Association of Arcahomo with Pacao is the prime reason for suggesting that the Arcahomo may at some time have lived in the general Three Rivers area. As noted earlier, the name Arcahomo bears some resemblance to the name Como, which was recorded by Cabeza de Vaca some 200 years earlier. Although both names may refer to a group or groups that lived south or southeast of Three Rivers, a 1 inkage between the two names cannot be demonstrated by citing documents written during the intervening 200-year period.

Orejón. Orejón is a Spanish word which, when applied to an Indian group, denotes something distinctive about their ears, most probably large size. The Orejón were first recorded at San Antonio missions in 1731. It is possible that the group designated as Orejón (or Orejones) was earlier known by one or more native names, but no documents have been found which establish linkages.

It seems to be reasonably clear that the Orejón 1 ived somewhere inland between the lower Nueces and the lower San Antonio Rivers (Cabe110 1780b:37-38; Santa Ana 1743:69; Uribe Larrea 1958:473-474). This would place them east or southeast of Three Rivers and at a distance no greater than 70 miles. They may, however, have lived el sewhere at an earlier time. Cabello indicates that in 1780 some of the Orejón, along with remnants of 10 other Indian groups from southern Texas and northeastern Mexico, were still living somewhere between the mouth of the Nueces River and what is now St. Joseph Island, presumably 
in San Patricio County and the southern part of Aransas County. At that late date the Apaches were very active in southern Texas.

Most of the Orejon who entered Spanish missions went to San Juan Capistrano, which was established at San Antonio in 1731. Since the registers of this mission have not been found, it is not possible to develop a population figure based on ethnically identified individuals. One document supports the conclusion that there could not have been more than 50 Orejon at San Juan Capistrano at any one time (Dolores 1762a:49; Habig 1968:164). In 1737 most of the Indian residents of San Juan Capistrano ran away from that mission, and it is said that only three Orejón remained (ibid.). Most of the fugitive Orejón later returned, although a few of them may have gone to Mission San Francisco Vizarrón of northeastern Coahuila (Guadalupe 1754b:176-177 and 1754c:176). Several Orejón individuals from San Juan Capistrano accompanied missionaries to the short-lived missions established on the San Gabriel River northeast of Austin in 1748 (Bolton 1914:378). Descendants of the Orejón who originally entered San Juan Capistrano were reported there in 1789 (Habig 1968:175). Some Orejón appear to have also entered Mission Nuestra Señora de Ta Purísima Concepción de Acuña of San Antonio, since the surviving marriage register identifies two adult Orejón females in an entry for the year 1744.

Garcia (1760:title page) indicates that the Orejón spoke a dialect of the Coahuilteco language while at San Antonio missions, and it has been assumed that this language was spoken by them prior to entering missions. Guadalupe (1754c:176) makes it clear that the Orejon and Pamaque, who intermarried before entering missions, did not speak the same language (dialect?), and López (Habig 1968:175) implies that the Orejón spoke a language different from the languages spoken by Pamaque and Malaguita. Bolton's statements about relationships between the Orejón and Pamaque are discussed in the section on Pamaque. Ruecking's (1955:24) Orejón-cluster concept, which includes some Indians groups from other areas, needs revision.

Pacao. Although the names are similar, it is clear that the Pacao are not the same people as the Pacoa. Garcia (1760:title page) 1ists both groups as speaking dialects of the Coahuilteco language, and various sources indicate that the Pacoa lived to the west of the Pacao and entered missions in northeastern Coahuila (Campbel1 1979).

The Pacao are mentioned in documents that refer to the simultaneous foundation of three missions at San Antonio: Nuestra Señora de la Purísima Concepción de Acuña, San Francisco de la Espada, and San Juan Capistrano (Espinosa 1964:747; Pérez de Mesquía 1731:36). It is sometimes assumed that substantial numbers of the Pacao entered each of these missions, but no evidence has been found which supports this assumption. The available information indicates that most of the Pacao went to Mission San Francisco de la Espada. Several sources refer to all the Pacao fleeing from this mission in 1737 and 1 ater being persuaded to return (Orobio y Bazterra 1737:44-45 and 1738:46;

Ysasmendi 1737:41-42). Documents pertaining to a murder case of 1752 contain the testimonies of 13 adult male Pacao from Mission Espada (Proceedings 1752:250-275). No records refer to Pacao individuals at San Juan Capistrano, and the only Pacao individual recorded at Mission Concepción was a woman said to have come from Espada (Concepción Marriage Register 1742:No. 49). A single Pacao female was recorded at Mission San Antonio de Valero (Valero Baptismal Register 1745: No. 702). 
The records do not permit linkage of the Pacao with one or more speciflc localities at any time before first entering missions at San Antonfo. Such evidence as is available suggests that they originally lived in southern Texas southeast of San Antonio. In 1743 Santa Ana (1743:69) mentioned that "Pachaos" were among the Indians who came to San Antonio missions from the jurisdiction of Presidio de la Bahía (at modern Goliad), which would indicate an area nearer to the coast than to San Antonio. In 1780 Cabello (1780b:37-38) 1isted "Pacagues" among the ethnic group remnants sti11 living in the area between the lower Nueces River and St. Joseph Island, perhaps in San Patricio and southern Aransas Counties. Presumably these Pacagues are the Pacao, for Cabello says that some of them had previously entered Mission San Francisco de Ta Espada of San Antonio. Thus the best that can be done here is to state that, prior to 1731, the Pacao probably lived between the Nueces and San Antonio Rivers somewhere east or southeast of Three Rivers.

Pajalat. The only documents which report Pajalat in a specific locality were produced in 1727 and indicate that this group was then living near the lower San Antonio River, apparently in the area of present Goliad County. In 1727, when Sevillano de Paredes (1727:49) was visiting Mission San Bernardo in northeastern Coahuila, he reported that the "Pajalaques," a group with a population of about 200, were then living on the lower San Antonio River about 40 leagues (104 miles) from San Bernardo. The distance figure is inaccurate because no part of the San Antonio River is that close to San Bernardo, but the location on the lower San Antonio River is confirmed by a map compiled in the same year by Âlvarez y Barreiro (Wheat 1957, I:Map No. 115), who was in Texas with Pedro de Rivera, that shows the tierra de los Paxalatames $y$ otras naciones on the west side of the San Antonio River in the vicinity of western Goliad County, or some 30 to 40 miles eastnortheast of Three Rivers. Several years after these records were made, the Pajalat began to be recorded as one of the Indian groups that entered Mission Concepción at San Antonio. If at an earlier time the Pajalat lived elsewhere, their name is not recognizable in primary documents. Santa Ana (1743:69) noted that the Pajalat territory was in the jurisdiction of Presidio La Bahía (at modern Goliad).

The somewhat confused later report of Cabe110 (1780b:37-38) implies that in 1780 some of the Pajalat were still living under native conditions in the area that Ties between the lower San Antonio and lower Nueces Rivers. This is probably the source of the few Pajalat later recorded at Mission Nuestra Señora del Refugio of present Refugio, Texas.

Apparently most of the Pajalat who entered Spanish missions went to Nuestra Señora de la Purísima Concepción de Acuña, which was established at San Antonio in 1731. Various sources imply that the Pajalat were among the three most important groups represented at the mission (Dolores 1762a:47; Espinosa 1964:747; Pérez de Mezquía 1731:36). The marriage register of Mission Concepción has been preserved, and this permits a total of 33 adult Pajalat to be identified in entries extending from 1733 through 1766. of these 33 adults, 22 are males and 11 are females.

A few Pajalat from Mission Concepción were taken by missionaries to three missions founded on the San Gabriel River northeast of modern Austin in the 
middle eighteenth century. These were used as teachers and interpreters (Bolton 1914:378). López (Dabbs 1940:7) noted that by 1789 the Pajalat at Mission Concepción were commonly referred to as "Paxalotes, or Paxalaches," and that this form of the name was being applied to descendants of other Indian groups who had entered the mission. At least one Pajalat may have entered Mission San Antonio de Valero of San Antonio. A baptism of 1730 identifies an adult female as a "Pasatlath."

An adult female "Pajalachi" is recorded in the baptismal and burial registers of Mission Nuestra Señora del Refugio after the mission was moved to present Refugio, Texas, in 1795. This woman, who is identifiable in entries for the years 1809, 1812, 1815, and 1819, is the last Pajalat individual to be recorded anywhere.

A fortuitously preserved speech sample (Vergara 1965) indicates that the Pajalat spoke a dialect of Coahuilteco (Goddard 1979). According to López (Dabbs 1940:7), the Pajalat dialect was in common use at Mission Concepción as late as 1789, which suggests that in earlier years Pajalatspeakers may have been numerically dominant at this mission. The marriage register of Mission Concepción lists the Pajalat by Spanish personal names, but the native names of two Pajalat individuals are also given: 0el (male) and Ayatam (female).

Pamaque. The available evidence indicates that Pamaque (sometimes written as Pamache) is a collective name which means "people of the south." It was used in certain missions to refer to individuals and families of at least five groups whose formal names are rendered as Camasuqua, Sarapjon, Taguaguan, Tinapihuaya, and Viayan (Guadalupe $1754 a, b, c$ ). Prior to 1733 these five groups are said to have lived along the lower Nueces River west and northwest of Nueces and Corpus Christi Bays. This would place them at that time mainly in the inland or western portions of Nueces and San Patricio Counties, some 50 miles southeast of Three Rivers. The five group names, as well as Pamaque, do not resemble names recorded by Cabeza de Vaca for groups of the same general area almost 200 years earlier. Only the Viayan seem to have been mentioned in documents prior to 1733. Espinosa (Maas 1915:36-37) refers to the "Bioy" as living somewhere in southern Texas in 1708. Bolton (in Hodge 1910, II:196) is probably incorrect in equating the Panague with the Pamaque, since Sevillano de Paredes (1727:49-50) in 1727 refers to the Panague as living some 150 miles farther up the Nueces River than the Pamaque.

Pamaque individuals are recorded for at least six different Spanish missions: four missions of San Antonio; one at Refugio, Texas; and one mission, San Francisco Vizarrón, in northeastern Coahuila, Mexico.

The largest number of Pamaque probably entered Mission San Juan Capistrano of San Antonio, most of them during the period 1733-1735 (Cabel10 1780b:37-38; Dolores 1762a:49 and 1762b:169,178,182; Guadalupe 1754a,b,c:passim; Martinez 1754:168; Rábago y Terán 1754:93-94; Rodríguez 1755:184). Guadalupe gives the names of 17 individuals ( 7 males, 10 females) whose names he found in the San Juan Capistrano registers up to the year 1754. The Capistrano registers later disappeared and have not been found. It is probable that no more than 50 Pamaques were at this mission at one time. 
Bolton (in Hodge 1910, II:196) has said that before 1748 the "Pamaches" were numerous at Mission Nuestra Señora de la Purísima Concepción de Acuña of San Antonio. This is not supported by the sole surviving register (marriage), which identifies only seven adult Pamaque individuals (five males, two females) for the period 1734-1775. For Mission San Antonio de Valero, one "Pamqua" male is identified in a marriage register entry of 1748; and a legal document of 1752 mentions one "Pamaqui," a cook, at Mission San Francisco de la Espada of San Antonio (Bexar-Archives Translations, Vol. $24: 276-277$ ).

Cabe110 (1780b:37-38) notes that some Pamaque were still 1iving under native conditions near the lower Nueces River in 1780, and these probably later entered Mission Nuestra Señora del Refugio, whose registers (Matamoros Archives) identify seven Pamaque (three males, four females) for the period 1807-1825. In 1821 a few Pamaque were said to be working on a Refugio mission ranch located on the northern end of Padre Island (Oberste 1942: 291-295).

The few Pamaque at Mission San Francisco Vizarrón of northeastern Coahuila, which was founded in 1737, all appear to have been refugees from Mission San Juan Capistrano (Guadalupe 1754a,b,c:passim). At least seven Pamaque were present at Vizarrón prior to 1754 , but five of these made up one family (father Tinapihuaya, mother Viayan).

Garcia's (1760:title page) indication that the Pamaque and Orejon were mission Indians who spoke different dialects of Coahuilteco has been generally accepted, but Goddard (1979) has recently expressed doubt that either group spoke Coahuilteco before entering missions. It may be noted that Guadalupe (1754b:176) makes it clear that the Pamaque did not speak the same language (lengua) as their neighbors, the Orejon. He points out that the two groups had intermarried before entering missions and that each had learned the language of the other so well that both were bilingual. Since no identifiable samples of Pamaque and Orejón speech have survived, it is not possible to determine just how different the two languages actually were. Martinez (1754:168) records the native personal names of two Pamaque individuals: Jasampamo or Tasampamo (male) and Choopal (female).

Pampopa. The Pampopa seem to have been, at least numerically, one of the more important groups that ranged over the Three Rivers area during the first half of the eighteenth century. They were recorded more frequently than other groups, and at least 15 readily recognizable variants of the name occur in various primary documents.

In 1708 the missionary Isidro Féliz de Espinosa (Maas 1915:36-37) recorded "Panpoc" as the name of a group of Indians then living east of three missions previously established (1700-1702) in northeastern Coahuila: San Juan Bautista, San Francisco Solano, and San Bernardo. It seems likely that Espinosa was referring to a section of the Nueces River roughly midway between the modern cities of San Antonio and Laredo. This section is due east of the three Coahuila missions and is where later sources place the Pampopa. 
The next year, 1709, Espinosa accompanied a Spanish party on a trip from Presidio San Juan Bautista northeastward to a locality on the Colorado River a short distance downstream from modern Austin (Tous 1930:4-5). On Apri1 12 this party encountered "Pampoa" Indians on the Medina River southwest of the site of San Antonio, evidently near the boundary between Bexar and Medina Counties, where the Medina River flows from west to east before turning again southeastward. In this area the Spaniards first visited a Payaya encampment on the left bank of the river, and three leagues farther east they met some Payaya individuals, apparently from the settlement just visited. A little farther on they met five Pampopa Indians who were on their way to visit the Payaya settlement. Still farther eastward on the Medina River they came to a Pampopa encampment. Here the Spaniards employed a Pampopa guide, allowing him to ride a Spanish horse, and the Spanish party was followed by 12 other Pampopas on foot.

After returning from the Colorado River, on April 24, the Spaniards revisited the same Pampopa encampment. They were met outside the camp by the Pampopa population, accompanied by a "Paxti" (Pastia) leader. This suggests that the Pampopa encampment had either included some Pastia Indians on April 12 or had been joined by Pastia shortly thereafter. At any rate, the record shows friendly relationships between Pampopa and both Payaya and Pastia at this time. The Spanish party again asked for a Pampopa guide to take them by the shortest possible route back to San Juan Bautista. This guide, instead of leading them southwestward, led them southeastward into a region of sandy soils and thick woods, evidently across a portion of the southwestern terminus of the Post Dak Belt region in northern Atascosa County. Although it is not so stated, this guide was probably dismissed. The Spanish party then turned to the southwest.

The Espinosa record provides information on how long the Pampopa encamped at one site. This particular springtime encampment on the Medina River was occupied for at least 12 days. When Espinosa was at the Payaya encampment he noted that pecan trees were common along the Medina River and said that the nuts were used as food by all the Indians who encamped along its banks.

In 1717 the Frenchman, St. Denis, reporting on a trip from Natchitoches to San Juan Bautista on the Rio Grande, mentioned "Pampop" among the Indians who ranged the territory between the Medina River and the Rio Grande southwest of present San Antonio (Shelby 1923:177-179). He summarized the cultural characteristics of various Indian groups seen between the Hasinai Caddo country and the Rio Grande, and some of his remarks probably apply to the Pampopa. Among other things, he mentioned hunting, fishing, and plantfood collecting (roots, tubers, and fruits of trees); riding horses; use of bow and arrow; male group leaders; and occasional warfare with Spaniards, Apaches, and unspecified coastal Indian groups.

In 1727 Sevillano de Paredes made an inspection of two missions, San Juan Bautista and San Bernardo, located near present Guerrero in northeastern Coahuila. In his report Sevillano de Paredes $(1727: 42-43,48)$ included 10cational data on several Indian groups still living native style in the surrounding area. He referred to the Pampopa as a nación of about 500 
persons that was living on the lower or more southerly section of the Nueces River about 22 leagues ( 57 miles) from the two missions. If this distance estimate is taken literally, it places the Pampopa along the Nueces River in modern Dimmit and La Salle Counties. Near the Pampopa, he said, lived three other groups: Tilijae, Patacal, and Cachopostal. He also said that these Indians along the Nueces had relatives in the Coahuila missions and frequently visited them. In a nineteenth-century compilation Orozco y Berra (1864:304) misinterpreted the report of Sevillano de Paredes and placed the Pampopa on the Nueces River 22 leagues south (al Sur) of Mission San Juan Bautista. Some writers have quoted Orozco y Berra without noting this discrepancy (Bancroft 1883, I:611; Chabot 1930:13).

A map drawn by Francisco Álvarez y Barreiro, an engineer who accompanied Pedro de Rivera on his frontier inspection of 1724-1728, shows the Pampopa territory in southern Texas as of the year 1727 (Wheat 1957, I:Map No. 115). The tierra de los Pampopas is indicated by tiny outline drawings of huts. Two hut clusters are shown: (1) six huts on the right bank of the Nueces River due east of Presidio San Juan Bautista, and (2) seven huts on the right bank of the lower Frio River near its junction with the Nueces River. The Nueces River location confirms the statement about the Pampopa made by Sevillano de Paredes in 1727. At this time it was believed that the Nueces River flowed into the Rio Grande instead of the Gulf of Mexico, and it is so shown on this map. In terms of modern maps, the Pampopa of 1727 were ranging an area in and around present-day La Salle, McMullen, and Live Oak Counties, an area which includes Three Rivers and the nearby Choke Canyon Reservoir. Another map published in 1768 by José Antonio Alzate y Ramírez presents essentially the same information and is obviously based on the earlier map of Alvarez y Barreiro (Wheat 1957, I :Map No. 149). It may be noted that placement of the Pampopa on specific sections of the Medina and Nueces Rivers gives an impression of the size of their foraging territory. The maximum distance between the river sections is roughiy 85 miles.

In 1719, uneasy because of Apache incursions, three Pampopa leaders appeared at Mission San Antonio de Valero and expressed interest in entering a mission (Margil 1719:13-14). It cannot be proved that any Pampopa entered this San Antonio mission, but two group names, Aponpia and Anapoppia, recorded in the mission registers for the years 1727 and 1734 , may be distortions of the name Pampopa. As only three individuals are involved, it is evident that the Pampopa could not have been a numerically important group at this mission.

Apparently a considerable number of Pampopa entered Mission San José y San Miguel de Aguayo after it was established at San Antonio in 1720, but the registers of this mission have not been found, making it impossible to identify and count Pampopa individuals. One document mentions that over 200 Pampopa had expressed a willingness to enter Mission San José (Marqués San Miguel de Aguayo 1720:16). The mission foundation record indicates that San José was established primarily for three Indian groups: Pampopa, Pastia, and Sulujam (Valdéz 1720:17-18). As a Pampopa leader was made governor of the mission Indian village in 1720, the Pampopa mission population was probably larger than that of either the Pastia or the Sulujam. 
Very little detail is recorded about Pampopa activities at Mission San José. In 1732 some Pampopa males accompanied presidial soldiers on a punitive campaign against Apaches north of San Antonio (Dunn 1911:232). On at least two occasions between 1731 and 1737 many, if not a11, of the Pampopa at San José became dissatisfied with mission conditions and fled to their former range, particularly to localities on the Frio and Medina Rivers (Bolton 1915:17). Pampopa ethnic identity was maintained in this mission up to the year 1790 (Dabbs 1940:8).

Various documents indicate the presence of Pampopa at Mission San Juan Bautista near the Rio Grande in northeastern Coahuila between the years 1734 and 1772. Six Pampopa individuals are identified in a mission census of 1734 (Garza Falcón 1734:17-18), and nine Pampopa families are said to have been at the mission in 1738 (Portillo 1886:283). In another mission census of 1772, 31 Pampopa are recorded (Rodriguez 1772:123-129). There may have been a few Pampopa at nearby San Bernardo, but for this there is only hearsay evidence (Weddle 1968:236).

The Pampopa are identified by Garcia (1760:title page) as mission Indians who spoke a dialect of Coahuilteco. This has been the basis for nearly al1 later statements about Pampopa linguistic status (Bolton, in Hodge 1910,II:197; Pimentel 1875, II:75; Powe11 1891:69; Swanton 1940:135; Troike 1959:2).

Pasnacan. The Pasnacan are known only from mission-related documents pro-duced after the year 1742. They can be 7inked with two missions, San Juan Capistrano of San Antonio and San Francisco Vizarrón of northeastern Coahuila. An unknown number of Pasnacan first entered San Juan Capistrano in 1743 (Guadalupe 1754a:91), and some of these seem to have deserted, ending up at San Francisco Vizarrón, where in 1754 they were recorded in documents concerning a jurisdictional dispute between the two missions. The "Tacasnanas" at Mission San José y San Miguel de Aquayo of San Antonio were Tacame, not Pasnacan, as suggested by Bolton (in Hodge 1910, II:206; see also Ysasmende 1739:47-48).

Bolton (in Hodge 1910, II:206) places the Pasnacan territory between the lower portions of the San Antonio and Nueces Rivers and says that the Pasnacan "were probably Coahuiltecan, since they were very closely related to the Pamaques, of which tribe they seem sometime to have been regarded as a subdivision." The primary documents cited by Bolton, as well as others not cited by him, do not strongly support his statements. The Pasnacan may have lived in the area indicated when first known, but the evidence is circumstantial. No primary document gives a location that precise. Santa Ana (1743:69) mentions the Pasnacan, along with nine other groups, most of which he says came to San Antonio missions from the jurisdiction of Presidio de la Bahía (at modern Goliad). No document supports Bolton's bel jef that the Pasnacan were closely related to the Pamaque. Guadalupe (1754b:179-180) states that Pamaque and Pasnacan are collective names that were used in referring to separate sets of Indian groups. He gives the formal names of five groups that were designated as Pamaque, but unfortunately he fails to 1 ist names of Pasnacan groups. Guadalupe (1754a:91) also states that the first Pamaque entered Mission San Juan Capistrano in 
1733 and that the first Pasnacan appeared there 10 years later, in 1743. El sewhere Guadalupe (1754b:176-177) cites a few cases of pre-mission intermarriages of Pamaque with other groups, but no Pasnacan individuals are involved.

The available records thus indicate that about al1 the Pasnacan and Pamaque had in common was residence at the same missions. They probably came from the same general area, since so many of the Indian groups at Mission San Juan Capistrano appear to have come from various localities in southern Texas south of San Antonio. No document has been found which says anything about the language spoken by the Pasnacan. The only Tinguistic evidence recorded is a native personal name of one Pasnacan leader (capitan) at San Juan Capistrano. This name, Copichin, may be of Pasnacan origin.

Pastia. This Indian group is known from a considerable number of eighteenthcentury documents, in which the following singular and plural variants of the name Pastia occur: Pasti, Pasties, Pastry, Pasttias, Patias, Paxti, and Postitos. Pastry, which appears only in a modern secondary source (Ximenes 1963:142), is evidently the result of a clerical error. Postitos is almost certainly a diminutive variant of Pasti or Paxti. The Patiri of southeastern Texas, who in the middle eighteenth century entered Mission San Ildefonso of present Milam County northeast of Austin, have sometimes been mistakenly equated with the Pastia of southern Texas (Castañeda 1938,III: 300; Gilmore 1969:27,49).

The identity of the Pastia Indians has been obscured by the treatment received in the Handbook of American Indians of North America. No separate article was prepared for the Pastia. In a brief article entitled "Pasteal," written by H. E. Bolton (in Hodge 1910,II:208), Pastia was suggested as a possible synonym for Pasteal, Bolton expressing it parenthetically as "identical?" Yet in the cumulative synonym section at the end of the same volume (ibid.:1117), Pastia and Pasteal were equated without any expression of doubt. Since Bolton's mention of Pasteal a new document has been published, a letter written by the missionary Mazanet in 1690 (Gómez Canedo 1968:160), which makes it clear that Pasteal is an early copyist's distortion of the name Pachal (compare Hodge 1910, II:208; Dictamen Fiscal 1716:105; and Gómez Canedo 1968:160). This means that Pasteal, as a corruption of the name Pachal, must be struck from the record as the identifying name of any Indian group. Pachal and Pastia are unquestionably names for two separate and distinct peoples. In various other Handbook entries, all written by Bolton (Hodge 1907,I:847 and 1910,II:93,197,206,666,756), the Pastia are referred to in connection with several missions at San Antonio, making it clear that Bolton was aware of the Pastia as an authentic group name and that the Handbook should have carried a formal entry for the Pastia. Apparently a part of the confusion is the result of inadequate communication between the editorial staff and one of the contributing authors.

When first known in the years 1707-1709, the Pastia were encountered by Spaniards in a few encampments shared with other groups in an area that extended from the lower Medina River near San Antonio southward to the great bend of the Nueces River in La Salle and McMullen Counties, a distance of approximately 85 miles. It seems evident that their territorial range 
covered substantial portions of the lower Frio River valley and probably included localities in the Choke Canyon Reservoir area west of Three Rivers.

In 1707, Diego Ramón, military commander of Presidio San Juan Bautista at modern Guerrero, northeastern Coahuila, was sent across the Rio Grande into present southern Texas to curtail the activities of various rebellious Indians, mainly from the northern frontier of Nuevo León (Ramón 1707:53-71; summarized by Weddle 1968:76-85). Ramón's detachment crossed the Rio Grande near the presidio, traveled northeastward, and on March 11 arrived at the junction of Arroyo de Caramanchel (modern Comanche Creek) with the Nueces River in what is now northern Dimmit County. The Nueces was crossed somewhere upstream from the junction, and Ramon proceeded slowly down the Nueces River for a distance of 28 leagues (about $73 \mathrm{miles)}$ to the great bend of this river in southern La Salle and McMullen Counties. On March 23, when he was at a point somewhere in southeastern La Salle County, Ramón encountered 16 "Pasti" from a nearby Indian encampment.

These 16 Pastia were evidently all adult males, since they volunteered to assist Ramón in finding and attacking "Pelones" from Nuevo León who had been inciting them to harass Spaniards. Ramón gave them tobacco and maize.

The Pelones referred to here were not Apaches, as has sometimes been assumed (Forbes 1959:134). Pelones was a Spanish collective name for certain Indian groups of northeastern Nuevo León who had distinctive native names but shared a special form of hairdress (Hoyo 1960:491-496; Ladron de Guevara 1969:18; León y otros 1961:158,188,285). The Pastia joined Ramón's soldiers during the ensuing campaign against the Pelones. Some of the Pastia may have accompanied Ramón back to Presidio San Juan Bautista, but no records have been found which verify this conjecture. So far as is now known, no Pastia were ever seen farther west than the Tocality where Ramón first encountered them.

Ramon's diary is the only document which gives even a partial population figure for the Pastia. If the 16 individuals were a11 adult males with families, it is possible to suggest that at least 50 or 60 Pastia were living along the Nueces River in 1707 .

In December 1708, when writing about the foundation of several missions in northeastern Coahuila during the preceding decade, Espinosa (Maas 1915:36) listed the names of various Indian groups who sti11 ranged over areas surrounding these missions (San Bernardo, San Francisco Solano, and San Juan Bautista). On a special list of 28 Indian groups said to be living to the east (por la parte de Oriente), mainly in present southern, Texas, he included the name "Paxti." Since Espinosa had been with Ramón on his campaign down the Nueces River in the preceding year, inclusion of the Pastia on this list was probably based on his own observations.

Espinosa gave no specific population figures for the ethnic groups which he identified as living in southern Texas in 1708, but he did make the statement that the temporary Indian settlements of that area sometimes contained as many as 300 to 400 individuals. He said nothing, however, about how many distinctively named groups might have been sharing the same encampment. All his figures do is suggest a probable maximum settlement size for the area at that time. 
In 1709 the same Espinosa accompanied a smal1 party of Spaniards from San Juan Bautista on the Rio Grande northeastward to a point on the Colorado River not far downstream from present-day Austin. Espinosa's diary (Maas 1915:62; Tous 1930:13) indicates that on Apri1 12 the Spaniards visited a Pampopa encampment on the Medina River southwest of modern San Antonio. This settlement was on that section of the river which flows due eastward before turning again to the southeast, or in the vicinity of the boundary line between Bexar and Medina Counties. On their return from the Colorado River the Spaniards again visited this same Pampopa camp. When the Spaniards approached, the Pampopa came out to greet them, and on this occasion Espinosa remarked that the chief of the "Paxti" (Pastia) Indians al so came out for greetings. Whether the Pastia were sharing the encampment with the Pampopa 12 days earlier, we cannot say. Possibly the Pastia joined the Pampopa at this 1ocality sometime between Apri1 12 and 24. The encampment sharing indicates close ties between the two groups in 1709 .

Pedro de Rivera made an inspection of presidios in northern Nueva España during the years 1724-1728 (Murphy 1937), and in 1727 inspected two presidios in Texas, San Antonio de Bexar (at San Antonio) and La Bahía or Nuestra Señora de Loreto (at Goliad). With Rivera was an engineer, Francisco Átvarez y Barreiro, who produced a map which shows the approximate location of at least some of the Pastia at that time (Wheat 1957,I: Map No. 115).

On the Barreiro map the present San Antonio River is labelled as the Medina River all the way to the Gulf coast. The Medina is joined by an important but unlabelled eastern tributary about one-third the distance from San Antonio to the Gulf of Mexico. This is undoubtedly what is known today as Cibolo Creek, which enters the San Antonio River in the northern part of Karnes County. Between the San Antonio River (Medina) and Cibolo Creek, but well above the junction, the Barreiro map shows four tiny hut symbols accompanied by the following legend: "Pastias and other nations small in number" (Pastias y otras naciones de poca entidad). It would appear that the symbols are placed near the present boundary between Karnes and Wilson Counties. There is now no way to determine if the hut symbols refer to four separate Indian settlements seen in 1727 by Rivera's party or if the symbols merely call attention to an area in which the Pastia and other groups were seen at the time. The latter seems more plausible.

This cartographic record, prepared by an engineer who actually visited the area in question, suggests that by 1727 the last remnants of unmissionized Pastia had, possibly because of increasing Apache pressures, abandoned their earlier recorded ranges somewhat farther west and, along with other ethnic fragments, had taken refuge in the woodlands of the Post Oak Belt. The locality indicated on the map is near the common route of travel between the two presidios at San Antonio and Goliad. Thonhoff (in Weddle and Thonhoff 1976) has delineated this route by both documentary and field studies.

In the formal report of Pedro de Rivera (1728:102-103 and 1945:125) the Pastia are merely mentioned as one of five Indian groups still living under native conditions in the general area of Presidio La Bahía (Goliad). He 
indicates that these peoples were hunters and gatherers, referring to them as wanderers (vagos) who shifted their encampments (rancherias) to take advantage of seasonal availability of wild plant products (las frutas) and fish. He comments on their submissiveness (son de Espiritu. . apagados), which is to be expected in discouraged remnants of hunting and gathering populations who had been displaced from their territories and were probably facing extinction.

Mission San José y San Miguel de Aguayo was founded in 1720 specifically for three Indian groups: Pampopa, Pastia, and Sulujam. In an official report of this mission's foundation on February 23, Juan Valdez (1720:17-19,22-23) identified the three groups, gave the Spanish names of their leaders, but failed to indicate the territorial range of each group. Other documents contain essentially the same information (Margil de Jesús 1720; Marqués de San Miguel de Aguayo 1720:17-20;01ivares 1720:10). Since the registers of Mission San José have not been found, it is not possible to determine just how many Pastia entered this mission when it was founded and how many came later. Of the three groups that originally entered the mission, the Pastia were probably not the most numerous, since Espinosa mentioned that the Pastia leader was not given a high office in the mission village organization set up by the missionaries.

While at Mission San José, and sometimes between the years 1731 and 1737 , the Pastia twice ran away from the mission and were forcibly returned by Spanish soldiers (Franquis Benites de Lugo 1737:247-249). On one occasion they went southward and were found by the soldiers at Atascosa Spring and a nearby swamp or bog, both of which seem to have been identified by Robert H. Thonhoff (letter, February 28, 1976) as a locality northwest of Poteet in northern Atascosa County. This is less than 40 miles west of their location on Barreiro's map of 1727. But on the second occasion the Pastia were found by Spanish soldiers in the hill country north of San Antonio.

Inspection reports indicate that the Pastia retained their ethnic identity at Mission San Jose until late in the eighteenth century. The Solis inspection report of 1767 referred to the Pastia (Forrestal 1931:20; Kress and Hatcher 1931:51). In the López inspection report of 1789 (erroneously given as 1785), the Pastia seem to be recorded under the name "Postitos" (Dabbs 1940:9), for it is said that two Indian groups, Pampopas and Postitos, had been at the mission longer than the other groups named. This appears to demonstrate that Postitos is a Hispanicized diminutive form of the name Pastias. If so, Spanish records of the Pastia cover a period that extends from 1707 to 1789 , or about 82 years.

H. E. Bolton (in Hodge 1910,II:93) has stated that the Pastia Indians were represented at Mission Nuestra Senora de la Purisima Concepción de Acuña, established at San Antonio in 1731, and that the first Pastia individual was recorded in the Concepción marriage records in 1741 . Inspection of the marriage records reveals that Bolton's remarks are misleading. The name Pastia is given as the native personal name for two individuals, both of whom are clearly identified as Tilpacopal Indians. The first entry is Marriage No. 26, for July 5, 1738, which records the marriage of Cayetano (native personal name given as Pastia), a Tilpacopal, to Ana de Jesús (native personal name given as Ayatam), a Pajalat. The second entry 
is Marriage No. 46, for May 3, 1741, which records the marriage of Juana (native personal name given as Juanita Pastia), a Tilpacopal, to Bernardo Salinas, a Pajalat. This situation is difficult to interpret, since for Mission Concepción we have no baptismal and burial records that can be checked against the surviving marriage records. What is clear is that two individuals, one male, the other female, were known to other mission Indians by the personal names Pastia and Juanita Pastia. This could be fortuitous, or it could be that both individuals were of Pastia descent but had come to be identified by the missionaries as Tilpacopal. Bolton's implication that Pastia individuals or families began to enter Mission Concepcion after the year 1741 is no longer acceptable. If we take the marriage records literally, no Pastia Indians were represented at this mission.

The Valdéz report of the foundation of Mission San José in 1721 seems to indicate that the Pampopa, Pastia, and Sulujam all spoke the same language (Valdéz 1720:18). Valdéz gives the name of the interpreter, Captain Lorenzo García, who was used to communicate with these Indians. As the Pampopa were named by Bartholomé García (1760:title page) as a mission Indian group that spoke Coahuilteco, it seems reasonable to conclude that the Pastia also spoke a dialect of the same language.

Pastia is a native name for which there is a recorded meaning in Spanish, a rare thing in documents that refer to the aboriginal peoples of southern Texas. According to Ramón (1707:62), Pastia in Spanish means chamuscados (yndios de nazion Pasti y que en lengua Castellana quiere dezir chamuscados). The basic meaning of the Spanish word chamuscado is scorched, seared, or singed. The final ti or tia in the name variants Pasti and Pastia is probably related to the verb tixam ("to burn"), given by Swanton $(1940: 44)$ in his Coahuilteco-English vocabulary. The name Pastia thus may refer to some distinctive cultural characteristic, now unidentifiable.

The information summarized above throws some light on relationships between the Pastia and other Indian groups of the surrounding area. The Pastia who came to Ramón in 1707 were interacting with Pelones who had been displaced by Spaniards in northern Nuevo León. It may be inferred that the Pastia resented the intrusion of Pelones, since they joined Ramón's soldiers in an attack on the Pelones.

It is evident that the Pastia were on good terms with the Pampopa and that they had approximately the same territorial range in the early eighteenth century. The Pastia shared an encampment with the Pampopa in 1708 and were willing to enter Mission San José with the Pampopa (and Sulujam) in 1720.

In 1720, 01ivares (1720:10), who favored the establishment of a second mission (San José) at San Antonio, stated that the Pastia and Pampopa were traditional enemies of the Indians who were then at Mission San Antonio de Valero. Inspection of the baptismal, marriage, and burial registers of Valero, through the year 1720, indicates that 01 ivares was referring primarily to the following groups as enemies: Pamaya, Pataguo, Patzau, Payuguan, Payaya, Siaguan, Sijame, and Zarame. There is a plausibility to 01 ivares' statement, for the groups 1 isted above originally ranged to 
the west and northwest of the Pastia and Pampopa. Perhaps the stated hostile stance reflected former disputes between adjacent populations.

Patumaco. The Patumaco are known only from the marriage register of Mission Nuestra Señora de la Purísima Concepción de Acuña of San Antonio. This contains the names of at least 28 Patumaco adults (16 males, 12 females) in entries for the period 1733-1762. The Patumaco must have been closely related to the Pajalat, Siquipil, and Tilpacopal, because one male Patumaco, Joseph Flores, is identified as the governor of the newly organized Indian village and also as a leader (capitán) of the Pajalat, Siquipil, and Tilpacopal. The Patumaco may have spoken the Pajalat dialect of Coahuilteco and may also have been one of the unnamed Indian groups implied by a legend on the Alvarez y Barreiro map of 1727 (Wheat 1957, I:Map No. 115), which locates the tierra de los Paxalatames $y$ otras naciones on the west side of the San Antonio River in the vicinity of present western Goliad County, some 30 to 40 miles east-northeast of Three Rivers.

Piguique. These are sometimes 1 isted as an Indian group native to northeastern Coahuila (Figueroa Torres 1963:62; Orozco y Berra 1864:73,307), but this is not demonstrable. They can be linked only with an area in Texas that lies between the lower sections of the Nueces and San Antonio Rivers, on the mainland and also, perhaps seasonally, on the offshore islands (Bolton 1915:15-16,97). Dolores (1762b:182b) refers to the Piguique as a coastal people (costeños) from an area south (southeast?) of San Antonio, and Rubi (1768:40) lists the "Piguicanes" among Indian groups who lived in the coastal marshes (las marismas de la costa). Thus such evidence as is available suggests that their area after 1750 was some 50 to 75 miles southeast of Three Rivers.

Bolton (in Hodge 1910, II:147,196,248-249), apparently on the basis of association in missions, claims that the Piquique were closely related to several other groups, particularly the Orejon, Pamaque, and Pasnacan. The primary documents, however, lend little support to this judgment. It is not possible to show that the Piguique were more closely related to these three groups than to other groups reported in the same area. Perhaps the most informative statement about the Piguique is made by Guadalupe (1754b:179), who says that Piguique was a general name used to refer to several groups having specific names. It is regrettable that he fails to list these specific names.

Most of the Piguique who first entered missions apparently went to San Juan Capistrano of San Antonio, which they initially entered in 1747 (Guadalupe 1754b:179), but the number of individuals there at any one time seems never to have been recorded. Some Piguique, apparently not very many, left San Juan Capistrano and went to Mission San Francisco Vizarrón of northeastern Coahuila, and these are mentioned in documents pertaining to a jurisdictional dispute between the two missions in 1754 (Guadalupe $1754 \mathrm{c}: 178)$. One adult male Piguique is recorded in the marriage register of Mission Concepcion for the year 1756, and the entry notes that this individual had come from nearby Mission San Juan Capistrano. In 1768 an unspecified number of "Piguican" were said to be at Mission Espíritu Santo de Zuñiga at present Goliad (Bolton, in Hodge 1910, II:248-249). One adult Piguique is recorded in an entry in the burial register (1807) of Mission Nuestra Señora del Refugio at Refugio, Texas. 
Garcia (1760:title page) makes it clear that the Piguique did not speak a Coahuilteco dialect, since he says that only the Piguique children in missions could speak Coahuilteco. This has sometimes been ignored and the Piguique have been classified as speakers of Coahuilteco. Guadalupe (1754b:179) states that the Piguique spoke a different language from other Indian groups at San Juan Capistrano (no solo distinta sino dibersa). As no identified sample of Piguique speech has been recorded, there is no way to determine its affiliations (Goddard 1979).

Pitalac. The Pitalac are somewhat confusingly associated with the three missions that were established at San Antonio in 1731: Nuestra Señora de 1a Purísima Concepción de Acuña, San Francisco de la Espada, and San Juan Capistrano. It is recorded that three Indian groups, Pacao, Pajalat, and Pitalac (or Pitalaque), were persuaded to enter the three missions before they were formally established. Their combined populations were estimated to consist of over 1000 individuals, a figure that is probably exaggerated (Espinosa 1964:747; Pérez de Mezquía 1731:36). The records do not make it clear whether some of the Pitalac entered each of the three missions. Most of them evidently entered either Espada or San Juan Capistrano, probably the latter. One source (ibid.) mentions that the Pitalac were also known by an alternate name, Alobja, which has not been found in other documents.

The name Pitalac does not appear in the extant marriage register of Mission Concepción, but in this register four adult "Patalca" individuals (two males, two females) are identifiable. Since the name Patalca never appears in other primary documents, it seems reasonable to conclude that Patalca as recorded at Mission Concepción is merely a variant of the name Pitalac, resulting from transposition of the last two letters. This receives some support from the fact that in one register entry (Marriage No. 76) a Patalca female is said to have a sister living in nearby Mission San Juan Capistrano, where the Pitalac were probably present in the largest numbers. These interpretations lead to the further conclusion that Patalca is not a valid ethnic group name, as has long been assumed (Branda 1976:709; Hodge 1910, II:93,182-183; Ruecking 1955:344; Santos 1966-1967:157).

One adult Pitalac male, who was probably from one of the San Antonio missions, is identified in a 1772 census of Indians residing at Mission San Juan Bautista near the Rio Grande in northeastern Coahuila (Rodriguez 1772:129).

H. E. Bolton (in Hodge 1910,II:435) thought that the Pacao, Pajalat, and Pitalac came to the San Antonio missions from the Frio and Nueces Rivers, presumably meaning somewhere near the junction of the two streams. Just how he arrived at this judgment is not clear, because no documents have been found which support it. It is not possible to place the Pitalac in any particular part of southern Texas except on the basis of their apparent pre-mission association with the Pajalat. Two documents indicate that prior to 1731 the Pajalat were living in an area west of the San Antonio River and in the vicinity of present western Goliad County, or some 30 to 40 miles east-northeast of Three Rivers (Sevillano de Paredes 1727:49; Wheat 1957, I:Map. No. 115). 
After recent reexamination of the evidence, I withdraw earlier published statements (in Branda 1976:709,736) about the location and identity of the Pitalac Indians. This group cannot be placed in northeastern Coahuila, and its name cannot be equated with such recorded group names or name variants as Pataloque, Patuleco, Pita, and Pittales. Ewers (in Berlandier 1969:101n) has suggested that "Pitalas," which is a demonstrable misreading of Pitalac, may be a variant of the name Pitahay. No evidence has been found which supports Ewers' suggestion.

The pre-mission association of the Pacao, Pajalat, and Pitalac, and the use of a single interpreter when the three groups first came to San Antonio, suggest that the Pitalac may have spoken the Pajalat dialect of the Coahuilteco language.

Sanipao. The Sanipao are known only from documents pertaining to Mission Nuestra Señora de la Purísima Concepción de Acuña of San Antonio, whose surviving marriage register indicates that at least 32 adult Sanipao (14 males, 18 females) were there between the years 1753 and 1776 . It thus appears that documents (Dabbs 1940:7; Revi11a Gigedo 1966:66) which state that the Sanipao entered this mission when it was founded in 1731 are in error. No documents say anything about the area from which the Sanipao came. One can only speculate that, like most of the Indians represented at Mission Concepción, the Sanipao before 1753 lived somewhere in southern Texas south of San Antonio and may at some time have been in or near the Three Rivers area.

Most modern secondary sources identify the language spoken by the Sanipao as Coahuilteco, but Garcia (1760:title page) clearly states that only the younger Sanipao at missions spoke Coahuilteco. The evidence available thus suggests that the Sanipao spoke some other language, possibly one for which no sample has ever; been recorded (Goddard 1979).

Siquipil. The Siquipil are known only from documents that pertain to Mission Nuestra Señora de la Purísima Concepción de Acuña at San Antonio. The marriage register of this mission contains the names of at least 16 Siquipil adults (12 males, 4 females) in entries for the years 1733-1756. Circumstantial evidence in the Concepcion register indicates that the Siquipil were closely related to the Pajalat, Patumaco, and Tilpacopal. The first recorded marriage (July 9, 1733) was that of Joseph Flores, a Patumaco, who is identified not only as the governor of the newly organized mission Indian village but also as a leader (capitan) of the Pajalat, Siquipil, and Tilpacopal. The four groups named probably all spoke the Pajalat dialect of Coahuilteco, and this is supported by the similarity of two female personal names recorded in the Concepcion register: Ayatam (Pajalat) and Pilayatam (Siquipil). It thus appears 1ikely that the Siquipil were one of the unspecified groups implied by a legend on the Alvarez y Barreiro map of 1727 (Wheat 1957, I:Map No. 115) which 10cates the tierra de los Paxalatames $y$ otras naciones on the west side of the San Antonio River in the vicinity of western Goliad County, some 30 to 40 miles east-northeast of Three Rivers.

Siupam. In the Handbook of American Indians North of Mexico (Hodge, I:239 and 1910, II:584,756-757), there are separate entries for Chayopin, Tiopane, Tiopines, and Siupam, all of which are probably names for the same Indian 
group. The name Siupam appears in the earliest documents; the remaining three names are recorded in documents that pertain to the San Antonio missions.

In 1708 Espinosa (Maas 1915:36-37) 1isted "Xipam" among the Indian groups then still living in what is now southern Texas, and in 1709 Espinosa (Tous 1930:5) visited an encampment of "Siupan" and other Indian groups in what is now the city of San Antonio. Later, when he revisited the same locality, Espinosa noted that all of the Indians had moved farther down the San Antonio River.

The Siupam were evidently represented at all five of the San Antonio missions, although not at the same time. "Scipxames" are said to have been one of the Indian groups for which San Antonio de Valero was originally founded (Dabbs 1940:6). Bolton (in Hodge 1910, II:197,206,756-757) found documents which indicated that "Chayopines" and "Sayopines" were at San José y San Miguel de Aguayo when it was founded but had later deserted that mission. At least two "Chayopines" were at Nuestra Señora de la Purísima Concepción de Acuña (Marriages Nos. 78-79, 1746), and one of these had been killed by Apaches. "Siguipam" were listed as one of 10 Indian groups represented at San Francisco de 1a Espada (Balverde 1967:278). "Chayopines" and "Sayopines" were evident7y at San Juan Capistrano in considerable numbers (Cabe110 1780b:37-38; Dolores 1762a:49 and 1762b:169).

The Siupam at various times seem to have lived along the San Antonio River from San Antonio at least as far south as present Goliad, and Cabello (1780b:37-38) mentioned that a few Chayopines were living east of the lower Nueces River as late as 1780. These, he said, were the same Chayopines who had gone to San Juan Capistrano. Bolton (in Hodge 1910, II:756-757) once stated that the Chayopines had lived somewhere on the Frio River, but this has yet to be confirmed by documentary evidence. The names "Chayopin" and "Chayopines" are included in several place names of the eighteenth century: a road crossing of the San Antonio River and three ranches, al1 in the vicinity of present Wilson County (Weddle and Thonhoff 1976:148,150,152).

Garcia (1760:title page) lists the Chayopines of the San Antonio missions among the Indian groups who spoke a dialect of the Coahuilteco language. Hodge $(1907, \mathrm{I}: 239)$ cites James Mooney as saying that the "Chayopin" were Tonkawa. No Spanish document has been found that in any way substantiates his statement.

A group known to the Spanish colonists of Nuevo Leon in the early seventeenth century is listed as "Cayupinas," but no further detail is given (León y otros 1961:191). This suggests a more southern location for the Siupam or Chayopin, but little can be made of such slight evidence.

Sulujam. The 7ittle that is known about the territorial range of the Sulujam clearly links them with the upper San Antonio River, particularly from present San Antonio downstream an unspecified distance. They were never reported in any other area, and remnants of their population entered two of the San Antonio missions. It seems reasonable to believe that their range included some lands lying between San Antonio and Three Rivers. No 
evidence supports the conclusion of Ruecking (1955:369) that the Sulujam were closely associated with the Pachal, whose pre-mission territory was well to the southwest of San Antonio, on the Frio and Nueces Rivers and beyond.

In 1708 Espinosa (1708:42-43) 1isted "Chaaaulames" as one of 28 Indian groups sti11 living in what is now southern Texas. Maas (1915:36-37) renders this name as "Chaadulames." It appears that Espinosa was referring to the SuTujam.

On April 13, 1709, a Spanish expedition, on its way to the Colorado River just below Austin, stopped at an Indian encampment near a spring at the head of the San Antonio River in the present city of San Antonio (Espinosa's diary, in Tous 1930:5,13). This settlement was shared by three Indian groups whose names were recorded as "Siupan" (Chayopin), "Chaulaames" (SuTujam), and "Sijames," and its population was estimated to be about 500 persons. Bolton (in Hodge 1910,II:584) has mistakenly given the estimate as 1000. Most of the Indians present were Siupam (Chayopin) and Sulujam. The encampment is sometimes interpreted as being near San Pedro Spring in San Antonio (ibid.; Weddle 1968:92), but Espinosa's diary clearly indicates that it was at a second spring a short distance to the north of San Pedro Spring, evidently the spring in present Brackenridge Park of San Antonio. When the Spanish expedition returned from the Colorado River and revisited the same locality on April 23, the site had been abandoned by the Indians, who were said to have moved farther down the San Antonio River.

Bolton (in Hodge 1910,II:584) has identified the "Chaulaames" of Espinosa's diary with the Xarame, stating that the San Antonio area was the "home of the Xarame." The Xarame are rather abundantly documented as having lived farther to the southwest, beyond the Frio River, and the "Chaulaames" of the San Antonio area are much more plausibly identified as the Sulujam.

The Sulujam seem to have entered only two Spanish missions, both at San Antonio. Most of them probably entered Mission San José y San Miguel de Aguayo. A mission foundation record (Valdéz 1720:17-19,22-23) indicates that Mission San José was initially founded in 1720 for three Indian groups, Pampopa, Pastia, and Sulujam, the last one being identified by the name variant "Suliejames." At that time a Sulujam leader was named as alcalde of the mission Indian village. As the early baptismal, marriage, and burial registers of Mission San José have not been found, it is not known just how many Sulujam entered that mission. It may be noted that later reports of mission inspections failed to list the Sulujam among Indian groups still living at San José.

One of the arguments made by certain missionaries for the founding of Mission San José was that the Pampopa, Pastia, and Sulujam were enemies of the Indians then present at Mission San Antonio de Valero (Buckley 1911:28-29). This enmity did not prevent some of the SuTujam from entering Mission San Antonio de Valero, whose registers permit the identification of at least 12 individuals (six males, six females) who lived there between the years 1719 and 1755. In entries of the San Antonio de Valero registers the name Sulujam is variously rendered as Chrelejan, Chulajam, Solaja, Sulajam, Ulugame, Zolajame, Zolajan, Ztolan, Zulaja, and Zulajam. 
Since the records imply that the Sulujam spoke the same language as the Pampopa and Pastia, and Garcia (1760:title page) has identified the Pampopa as being mission Indians who spoke Coahuilteco, it is possible that the Sulujam also spoke a Coahuilteco dialect (cf. Swanton 1940:135).

Tacame. No known document satisfactorily locates the Tacame before they entered missions. In 1728 Rivera (1728:102-103) referred to them as a hunting and gathering people who lived in the general vicinity of Presidio La Bahĩa, which at that time was at Mission Valley, northwest of present Victoria, Texas. Since in the same passage Rivera mentions Pampopa and Pastia, it is possible that the Tacame were then living somewhere southwest of the presidio. In 1743 Santa Ana (1743:69) said that they lived in the jurisdiction of Presidio La Bahía, which had been moved to present Goliad, and in 1780 Cabe110 (1780b:37-38) reported remnants of the Tacame and other groups living between the mouth of the Nueces River and present St. Joseph Island. These oblique references to pre-mission location suggest that when first known the Tacame ranged an area east or southeast of Three Rivers.

Spanish missionaries at San Antonio referred to the Tacame as fickle because they frequently shifted from one mission to another. Apparently the Tacame first entered Mission San José y San Miguel de Aguayo, but in 1736 they left it for Mission San Francisco de la Espada, from which over 200 Tacame are said to have fled in 1737 to an unspecified locality on the Colorado River (Franquis Benítez de Lugo 1737:246-247; Santa Ana 1737:380 and 1739:48). Later some of the Tacame entered Mission San Antonio de Valero, whose registers refer to six Tacame individuals in 1739. Eventually the Tacame settled down at Mission Nuestra Señora de Ta Purisima Concepción de Acuña, in whose surviving marriage register at least 56 adult Tacame (36 males, 20 females) are identifiable for the period 1742-1780. It is evident, however, that all of the Tacame did not enter missions prior to 1780, because Cabel10, as noted above, reported some of them sti11 living under native conditions in that year.

Garcia (1760:title page) indicated that in the San Antonio missions the Tacame spoke a dialect of Coahuilteco. At Mission San Antonio de Valero three personal native names are recorded for male Tacame individuals in 1739: Aimungen, Corpe1, and Unguen.

Tilpacopal. The Tilpacopal, Tike the Siquipil, are known only from documents relating to Mission Nuestra Señora de la Purisima Concepción de Acuña of San Antonio. The surviving Concepción marriage register identifies 20 Tilpacopal adults ( 12 males, 8 females) during the period 1733-1755. The Tilpacopal seem to have been closely associated with the Pajalat, Patumaco, and Siquipil, as the marriage register identifies one man, a Patumaco, as a leader (capitán) of the Pajalat, Siquipil, and Tilpacopal prior to mission entry. It is probable that the Tilpacopal spoke a Pajalat dialect of Coahuilteco and that they were one of the unnamed groups noted on a legend on the Âlvarez y Barreiro map of 1727 (Wheat 1957, I:Map No. 115), which locates the tierra de los paxalatames $y$ otras naciones on the west side of the San Antonio River in what is now western Goliad County. 
Comment. The later documents pertaining to the area under investigation here, all dating some 150 years after the time of Cabeza de Vaca, are not as informative as the Cabeza de Vaca documents. They yield very little cultural information. Their chief value lies in what is revealed about where various Indian groups lived before entering missions, about the languages which they spoke, and about the one or more missions at which each group was represented.

The association, sometimes rather tentative, of certain Indian groups with the Choke Canyon target area has been achieved by a process of elimination. Recorded data on numerous Indian groups of southern Texas and northeastern Mexico were examined for indications that, at one time or another, they were seen in or said to be living in or near the target area. No claim can be made that the groups identified above are the only groups that can be linked with the Choke Canyon area, since years of archival research are needed in order to find additional informative documents.

Thus far it has been possible to identify 17 Indian groups that ranged in or near the target area. The recorded information permits some groups to be located more precisely than others. It must be emphasized, however, that the recorded group locations are few in number and scattered over a considerable span of time. The Mariames of Cabeza de Vaca, who undoubtedly survived into the eighteenth century, are not included among the 17 groups because not enough information has been found to 1 ink them firmly with the target area.

Although the evidence is far from being satisfactory, it is possible to assign the 17 groups to various parts of the Choke Canyon target area. The Pampopa and Pastia are rather clearly linked with the western half of the target area and undoubtedly at times camped at localities which will be inundated when the reservoir is completed. A number of groups, particularly the Orejón, Pamaque, Pasnacan, Patumaco, Piguique, and Tacame, can be placed in the southeastern quadrant of the circular target area, a large part of which overlaps the territories of Cabeza de Vaca's Indians of Area 2. Seven groups appear to be relatable to the northeastern quadrant of the target area, with perhaps some extension westward into the northwestern quadrant. These last groups, Pacao, Pajalat, Siquipil, Siupam, Sulujam, and Tilpacopal, seem to have been the principal groups that ranged northeast of the Choke Canyon Reservoir and southeast of the city of San Antonio.

It is possible that some of these eighteenth-century Indian groups originally lived somewhat farther west, that is, farther from the Gulf coast. Their names, however, do not appear in accounts of early travel farther west along the road from San Juan Bautista (Guerrero, Coahuila) to San Antonio. The road from San Antonio to Laredo, which was not opened unti1 after 1750, was too late for travel records to mention Indian groups originally native to the area traversed.

It can be demonstrated that some Indian groups were displaced by Spaniards from northern Tamaulipas and northern Nuevo Leon into areas north of the Rio Grande, but we have been unable to associate any of these with the target area. 
A few eighteenth-century group names resemble some of Cabeza de Vaca's group names, and the resemblances have been noted in ethnohistoric literature. Most of the resemblances involve groups reported at such great distances from Cabeza de Vaca's traverse of southern Texas that the name resemblances are probably fortuitous. It thus appears likely that most of Cabeza de Vaca's groups lost their identities, or at least lost their earliest recorded names, during the 150-year period that remains undocumented. A fairly good case can be made for the persistence of one of Cabeza de Vaca's groups, the Mariames. For several others, such as Atayos, Coayos, Comos, Maliacones, and Yguazes, the evidence for continuity is merely suggestive, not conclusive.

It is clear that remnants of ethnic groups relatable to the Choke Canyon area were drawn mainly to the San Antonio missions, particularly to the three missions that were moved to San Antonio from eastern Texas in 1731. Relatively few of these Indians entered missions at Goliad and Refugio, probabiy because these missions were established too late to receive many survivors. It is obvious that eighteenth-century missionaries at San Antonio had little interest in describing the cultures of Indian groups represented at their respective missions. Some of them, however, did show an interest in recording certain dialects commonly spoken by the mission Indians. It was at these San Antonio missions that García and Vergara prepared manuals for the administration of church ritual that were written in both Spanish and Coahuilteco.

Eighteenth-century missionary reports very clearly state that some of the ethnic group names were actually collective names, apparently used by missionaries for convenience in reference. It is not stated that the Indians themselves also used these collective names. Only one collective name, Pamaque, is accompanied by names of its "subdivisions." These consist of Camasuqua, Sarapjon, Taguaguan, Tinapihuaya, and Viayan, most of which are not recorded in either earlier or later documents. The names Pasnacan and Piguique are also said to be collective names, but no referent groups are identified. This is regrettable, since some of the names might be similar to names recorded by Cabeza de Vaca.

The 17 Indian groups relatable to the Choke Canyon area apparently did not all speak the same language, although most of them probably spoke dialects of Coahuilteco. Six groups have been identified by missionaries as speaking dialects of Coahuilteco, at least when they were in the missions. These are Orejón, Pacao, Pajalat, Pampopa, Siupam (Chayopin), and Tacame. Certain contextual situations described in missionary reports suggest that six additional groups probably also spoke Coahuilteco: Pastia, Patumaco, Pitalac, Siquipil, Sulujam, and Tilpacopal. The Pamaque are said to have spoken a language different from that spoken by the Orejon, who are identified as Coahuilteco-speakers. The Piguique are unique in that they are said to have spoken a language quite different from other languages spoken at Mission San Juan Capistrano. For three groups, Arcahomo, Pasnacan, and Sanipao, we have no information about the language or languages spoken. Enough documentary evidence exists to indicate that Coahuilteco, because it was spoken by so many Indian groups at the San Antonio missions, eventually became the dominant language in the second and third generations of mission Indians. There is now no way to determine if any languages spoken in the eighteenth century were also spoken by Cabeza de Vaca's earlier Indian groups. 
The few references to group population size are difficult to evaluate because it is not possible to determine how many are based on eyewitness testimony and how many are merely based on local hearsay. The recorded figures range from 200 to 500. The larger figures may be based on observations of Indian encampments which were shared by two or more groups, which was not uncommon elsewhere in lower Texas after Apaches began to penetrate the area. Group population estimates derived from Spanish mission registers are not very informative because in most cases only remnants of ethnic groups chose to enter missions.

Some impression of maximum territorial range, along a north-south axis, may be obtained from recorded observations of Pampopa and Pastia encampments, which were distributed over an area extending from the Medina River southwest of San Antonio to the great southward bend of the Nueces River, a distance of approximately 85 miles. This approaches the figure which Cabeza de Vaca's data indicate for the maximum dimension of the Mariame range.

Very little information on subsistence has been recorded for these Indian groups. Rivera's observations are generalized and merely confirm the fact that all of the groups were hunters and gatherers. No reference is made to seasonal migration to prickly pear concentrations, and pecan harvesting is linked indirectly with two groups encountered on the Medina River southwest of San Antonio. Nothing is said about gathering pecan nuts along the lower Guadalupe and San Antonio Rivers.

Unlike the Cabeza de Vaca documents, the eighteenth-century documents sometimes refer to native group leaders, usually as political heads of several associated groups, but all of the information is derived from mission contexts. Behavioral detail is omitted, and we can only speculate that, when remnants of several groups habitually shared the same encampment, one man was designated to make or enforce important decisions, particularly during Apache attacks.

\section{Immigrant Apaches}

Documents pertaining to southern Texas after the time of Cabeza de Vaca initially recognized no subdivisions of the Athapaskan-speaking Apaches, merely referring to them as "Apaches." The name "Lipan" came into use later. It is clear that Apaches other than Lipan were sometimes in the area, for some accounts refer to "Apaches and Lipanes." Eventually all Apaches reported in southern Texas came to be referred to as Lipan Apaches. This use continued into the nineteenth century.

The movement of Lipan and other Apaches into southern Texas represents the final phase of Plains Apache southeastward expansion, and their presence in southern Texas during the second half of the eighteenth century was primarily the result of their displacement from the Edwards Plateau by Comanches and their allies. The expansion of Apache groups from the southern Plains into various parts of present-day Texas has been discussed in various publications (Dunn 1911; Newcomb 1961; Schroeder 1960; Tunnel1 and Newcomb 1969; Sjoberg 1953). Comanches, Tonkawas, certain Wichita groups, and a 
few groups from the Gulf coast at times hunted or raided in southern Texas, but only the Lipan Apaches and their as yet unidentified Athapaskan-speaking associates lived in southern Texas long enough for material residues of occupation to accumulate and be recovered by archaeological excavations, such as those of the Choke Canyon area.

The main concern here is with localization of Lipan Apaches in that part of southern Texas that lies within or near the Choke Canyon target area, particularly in the later part of the eighteenth century, when Lipan Apaches dominated the area. No attempt has been made to collect and synthesize observations of Lipan Apache culture during this period or later. Numerous observations are scattered through nineteenth-century Anglo-American documents, but these refer to small and very mobile remnant groups of Lipan Apaches who eventually moved westward into northern Coahuila, northern Chihuahua, and the adjoining parts of western Texas.

The eighteenth-century documents which refer to locations of Lipan Apache encampments are no more informative than the earlier documents which refer to locations of Indian groups native to southern Texas. Most of the information appears in routine military reports that originated in San Antonio. These refer to Lipan Apaches taking 7 ivestock (horses and cattle) from Spanish ranches along both sides of the San Antonio River between San Antonio and La Bahía (modern Goliad). Few Lipan Apaches entered missions at San Antonio and La Bahía.

The La Paz map, which was compiled circa 1783 (Wheat 1957, I:Map No. 195), shows "Apaches Lipanes" as occupying a11 of southern Texas east of Laredo and south of San Antonio, extending eastward as far as the upper part of Matagorda Bay. This distribution is not contradicted by documents of that time. Cabel10 (1780a:58-59) noted in 1780 that the Lipan were so demoralized by the Comanches of central Texas that they did not dare to leave the area south of San Antonio, and he mentioned that many Lipan Apaches were then hunting near the Gulf coast.

The most favored encampment area of the Lipan Apaches seems to have been along the Nueces River, particularly in present-day La Salle, McMullen, Live Oak, and Nueces Counties, most of which 1 ies within the Choke Canyon target area. From this territory the Lipan Apaches raided Spanish ranches between San Antonio and La Bahía (Cabe110 1782:53-54;1784a:113;1786:90-91), and also Spanish ranches along the Rio Grande from Laredo downstream to Camargo (Cabe110 1780c:43).

Lipan Apaches are several times reported as being encamped at a locality known to Spaniards as El Atascosa, said to have been 12 leagues (about 31 miles) south of San Antonio and also south of the Medina River (Cabe110 $1783: 167 ; 1784 \mathrm{~b}: 38$ ). This 1ocality seems to have been in what is now northern Atascosa County (see section on Pastia). The locality lies near the northern periphery of the Choke Canyon target area. In 1785 Cabel10 (1785a:91) mentioned that there were two or three Lipan rancherias between San Antonio and La Bahía, but he did not indicate specific localities. One of these may have been El Atascosa. 
Cattle taken from Spanish ranches along the San Antonio River were driven unspecified distances westward and butchered. The documents occasionally refer to Lipan forays of this sort as carneadas because cattle were butchered and the meat dried for later consumption elsewhere. Military parties from the presidio at San Antonio sometimes came across Lipan carneada sites, which were identifiable by large quantities of bones. Cabel1o (1785b:93) estimated that between 1778 and 1785 the Lipan Apaches had killed 22,000 head of cattle from ranches along the San Antonio River. This figure is undoubtedly exaggerated, since it is cited in support of a plea for reduction in the tax levied on range cattle.

Comment. Lipan occupation at favored localities in the Choke Canyon area did not involve a span of time long enough for very much cultural debris to be deposited. Lipan Apache encampments in that area probably were not marked by much cow-bone residue, since butchering was done elsewhere. Carneada sites may eventually be found along western tributaries of the San Antonio River, where bones may sometimes have been quickly covered by alluvium. In that area archaeologists should not be too hasty in attributing such concentrations of cow bones to Europeans.

\section{FINAL COMMENT}

In this study an attempt has been made to segregate, analyze, and synthesize most of the locational and cultural information recorded for each named Indian group that is relatable to the Choke Canyon Reservoir area of southern Texas. This has involved all the Indian groups named by Cabeza de Vaca for the area west and southwest of the lower Guadalupe River, as well as various groups named in documents written after the time of Cabeza de Vaca. Previous students of historic Indian groups connected with this area have not rigorously analyzed the data recorded for each ethnic unit, and this has led to numerous factual errors and faulty generalizations about the recorded Indian groups.

For archaeologists the observations of Indian groups recorded in the Cabeza de Vaca documents have special value because these observations were made early enough to give useful impressions of Indian life as it was in parts of southern Texas at the close of the Late Prehistoric period. The eighteenthcentury documents used in this study reveal that the Indians were living in a world radically different from that reflected by the Cabeza de Vaca documents. The northward advance of the Spanish settlement frontier had led to displacement of Indian groups from their traditional foraging territories, to population decline, and to merging of ethnic group remnants. The early Apache raids, followed by Apache immigration into the area, hastened the widespread loss of ethnic identities. The last remnants of the aboriginal groups either entered Spanish missions or joined the Lipan Apaches.

When one compares Cabeza de Vaca's recorded information on the Indians of southern Texas with information recorded in later Spanish documents, Cabeza de Vaca loom's large as an ethnographer. His knowledge of Indian cultures was based on participant observation. No Spaniard of later times actually 
lived with Indians of the area and survived to write about his experiences. Cabeza de Vaca is the only Spaniard who gave names for most of the groups he encountered, who indicated where each group lived relative to other groups, and who described in some detail the sociocultural behavior of specific Indian groups. His Mariames and Avavares are still the best described Indians native to southern Texas. His cultural information quantitatively exceeds that of all his successors combined. Cabeza de Vaca should be regarded as the first and indeed the only true ethnographer of southern Texas who was a contemporary of the Indians that he described.

The "trans-Texas" interpretation of Cabeza de Vaca's route has become more or less traditional among Texas historians, who seem to remain unaware of Krieger's very serious and damaging challenge of its validity. Krieger has shown that Cabeza's descriptions of terrain and Indian cultures observed after he turned westward fit northern Mexico far better than they fit central and western Texas. The trans-Texas route interpretation has recently become even more firmly entrenched, as is shown by five public school textbooks on Texas history that were published in 1972. Each textbook contains a map which shows Cabeza de Vaca's route as extending from the middle section of the Gulf Coast to the general vicinity of El Paso, every mile of it north of the Rio Grande (Connor and Pool 1972; Holz, Mayha11, and Newman 1972; Kowns 1ar 1972; Pearson, Procter, and Conway 1972; Reece and Kennamer 1972). We think that these recent textbooks should be revised. They should at least indicate that Cabeza de Vaca's westward route is controversial. 
REFERENCES CITED

Abbreviations used:
AGI Archivo General de Indias. Sevilla.
AGN Archivo General de la Nación. México.
BAE-B Bureau of American Ethnology, Bulletin. Washington, D.C.
BAT Bexar-Archives Translations. BTHCA.
BTHCA Barker Texas History Center Archives. The University of Texas at Austin.
NA Nacogdoches Archives. BTHCA. PITM Publicaciones del Instituto Tecnológico y de Estudios Superiores
PTCHS Preliminary Studies of the Texas Catholic Historical Society. Austin.
QTSHA See SHQ.
SA Saltillo Archives. Saltillo, Coahuila.
SFGA San Francisco el Grande Archives. México.
SHQ The Southwestern Historical quarterly (formerly quarterly of the Texas State Historical Association). Austin.

Balverde, Acisclos

1767 Memorial Del R. P. Presidte al Cap. ${ }^{n}$ del Presidio de S. ${ }^{n}$ Antonio para $q^{e}$ va inserta a fin de averiguar a ge mision pertenecen unos indios qe los minros de la Mission de N. O S. P. S. Franco de la Espada recogieron: Año de 1767. Santa Cruz de Querétaro, K, No. 19, Legajo 4. Dunn Transcripts, 1750-1767 (BTHCA, 2Q237, Vol. $768: 277-280)$.

Bancroft, Hubert Howe

1883 The Works of Hubert Howe Bancroft; Vol. I, Wild Tribes. San Francisco.

Bandelier, Fanny, translator

1905 The Journey of Álvar Núñez Cabeza de Vaca. New York.

Baskett, James Newton

1907 A Study of the Route of Cabeza de Vaca, I. 2TSHA 10(3):246-279.

Berlandier, Jean Louis

1969 The Indians of Texas in 3830 . Edited and introduced by John C. Ewers. Smithsonian Institution Press, Washington, D.C.

Bexar-Archives Translations

MS In BTHCA. 
Bishop, Morris

1933 The Odyssey of Cabeza de Vaca. New York.

Bollaert, William

1850 Observations on the Geography of Texas. Read before the Royal Geographical Society of London on the 14th of January, 1850 (1ater printed in Journal of the Royal Geographical society 20 (1851):113-135).

Bolton, Herbert E.

1914 The Founding of the Missions on the San Gabriél River, 1745-1749. SHQ 17(4):323-378.

1915 Texas in the Middle Eighteenth Century. Berkeley.

1916 Spanish Exploration in the Southwest, 1542-1706. New York.

Bourke, John G.

1931 The Folk-foods of the Rio Grande Valley and of Northern Mexico. Publications of the Texas Folk-lore Society 9:85-117.

Branda, Eldon Stephen, ed.

1976 The Handbook of Texas: A Supplement, Vo1. III. Texas State Historical Association, Austin.

Bray, Wi 11 iam L.

1901 The Ecological Relations of the Vegetation of Western Texas. Botanical Gazette 32:99-123, 195-217,262-291.

Brebner, John B.

1933 The Explorers of North America, 1492-1806. New York.

Buckley, Eleanor Claire

1911 The Aguayo Expedition into Texas and Louisiana, 1719-1722. RTSHA 15(1):1-65.

Cabe110, Domingo

1780a Domingo Cabello's letter No. 186 to de Croix... Bahía... Feb. 12, 1780. BAT, BTHCA, Vo1. 93(2C346):58-61.

1780b Expediente. Cabello submits his report concerning activities of some citizens of Nuevo Santander who buy and se11 Indians. BAT, BTHCA, 2C347, Vol. 96:33-39. 
1780c Official letter Number 299, Cabel 10 to de Croix, Oct. 20, 1780. BAT, BTHCA 2C350, Vol. 104:41-50.

1782 Status report and daily record of the cavalry company at San Antonio de Béxar for January, 1782, Jan. 31, 1782. BAT, BTHCA, 2C352, Vol. 109:50-54.

1783 Strength report and daily record of occurrences at the Royal Presidio of San Antonio de Béxar for April, 1793. BAT, BTHCA, 2C356, Vo1. 118:165-171.

1784a Domingo Cabe110's letter No. 844 to Fel ipe de Neve concerning hostile acts committed by the Indians and steps taken to deal with them appropriately, Béxar, June 20, 1784. BAT, BTHCA, 2C360, Vo1. 126:171-114.

1784b Strength report and daily record of occurrences at the Royal Presidio, San Antonio de Béxar, for January, 1784. BAT, BTHCA, 2C358, Vol. 122:34-41.

1785a Copy of Domingo Cabel10's official letter No. 78 to José Antonio Renge1, June 4, 1785. BAT, BTHCA, 2C363, Vol. 132:90-92.

1785b List of guias (export permits) for ore jano cattle and mustang horses issued by Domingo Cabe110 from 1779 to 1786 . BAT, BTHCA, 2C364, Vo1. 134:87-93.

1786 Draft of Domingo Cabel10's official letter No. 217 to Jacobo Ugarte. BAT, BTHCA, 2C366, Vol. 138:90-94.

Cabeza de Vaca. See Núñez Cabeza de Vaca.

Campbe11, T. N.

1979 Ethnohistoric Notes on Indian Groups Associated with Three Spanish Missions at Guerrero, Coahui la. Center for Archaeological Research. The University of Texas at San Antonio, Archaeology and History of the San Juan Bautista Mission Area, Coahuila and Texas, Report 3.

Castañeda, Carlos E.

1936 Our Catholic Heritage in Texas, 1519-1936; Vol. I, The Mission Era: The Founding of Texas, 1519-1693. Austin.

1938 Our Catholic Heritage in Texas, 1519-1936; Vol. III, The Mission Era: The Missions at Work, 1731-1761. Austin.

Chabot, Frederick C.

1930 Indians at Missions. San Antonio Series, No. 3. San Antonio. 
Concepción Marriage Register

MS This register is in the San Fernando Archives, San Antonio, Texas (see Santos, 1966-1967). Photostat and microfilm copies in the Texas Catholic Archives, Austin, Texas.

Connor, Seymour V., and William C. Pool

1972 Texas: The 28th State. Graphic Ideas, Inc., Austin-Dallas. Coopwood, Bethe1

$1899-$

1900 The Route of Cabeza de Vaca, Part I. 2TSHA 3(2):108-140; $4(1): 1-32$.

Corre11, Donovan S., and Marsha11 C. Johnston

1970 Manual of the Vascular Plants of Texas. Texas Research Foundation, Renner, Texas.

Covey, Cyclone, translator

1961 Cabeza de Vaca's Adventures in the Unknown Interior of America. Collier Books, New York.

Cuervo y Valdés, Francisco

1701 Testimonio de la Fundación de San Juan, año de 1701. AGN, Historia 29 (BTHCA, 20178, Vol. 348:5-16).

Dabbs, J. Autrey

1940 The Texas Missions in 1785. PTCHS 3(6).

Davenport, Harbert, ed.

1924 The Expedition of Pânfilo de Narváez, by Gonzalo Fernández Oviedo y Valdéz, Chapters IV and V. SHQ 27(4):276-304.

Davenport, Harbert, and Joseph K. Wells

$1918-$

1919 The First Europeans in Texas, 1528-1536. SHQ 22(2):111-142; $22(3): 205-259$.

Dictamen Fiscal

1716 Dictamen Fisca1, Mexico y Noviembre 30 de 1716. AGN, Historia 27 (BTHCA, 2Q177, Vol. 346:89-157). 
Dolores, Mariano Francisco de los

1762a Informe rendido por los ministros de las Misiones de el Rio de San Antonio a Fr. Francisco Xavier Ortiz. SFGA, Vol. 27, Leg. 99, No. 9 (BTHCA, 2Q256, Vol. 835:38-76.

1762b Fray Mariano Francisco de los Dolores and company to Fray Francisco Xavier Ortiz, March 6, 1762. BTHCA, 2Q177, Vol. 347:162-183.

Dunn, William Edward

1911 Apache Relations in Texas, 1718-1750. 2TSHA 14(3):198-274.

Espinosa, Isidro Féliz de

1708 Relación. AGI, Audiencia de México, 62-2-29 (BTHCA, 2Q146, Vol. $77: 29-48)$.

1964 Crónica de las Colegios de Propaganda Fide de la Nueva España, México, 1746. New ed. with notes and intro. by Leno G. Canedo. Academy of Franciscan History, Washington, D.C.

Figueroa Torres, J. Jesús

1963 Fr. Juan Larios: Defensor de los Indios y Fundador de Coahuila, 1673-1676. México.

Forbes, Jack D.

1959 Unknown Athapaskans: The Identification of the Jano, Jocome, Jumano, Manso, Suma, and Other Indian Tribes of the Southwest. Ethnohistory 6(2):97-159.

Forresta 1, Peter P.

1931 The Solis Diary of 1767. PTCHS 1(6).

Franquis Benites de Lugo, Carlos de

1737 Testimonio de Santiago Ximénez, en cattorce dias del mes de Agostto de Mi11 Septtecientos treyntta y siette. AGN, Misiones 21 (BTHCA, 2Q200, Vol. 453:244-249).

García, Bartholomé

1760 Manual para Administrar los Santos Sacramentos de Penitencia, Eucharista, Extrema-uncion, y Matrimonio . . Mexico.

Garza Falcón, Blas de la

1734 Yndios de la Mission. AGI, Audiencia de México (BTHCA, 2Q147, Vo1 84:15-19). 
Gilmore, K. K.

1969 The San Xavier Missions: A Study in Historical Site Identification. State Building Commission, Archeological

Program Report 16. Austin.

Goddard, Ives

1979 The Languages of South Texas and the Lower Rio Grande. In Lyle Campbe11 and Marianne Mithun, eds., The Languages of Native America: Historical and Comparative Assessment:

355-389. University of Texas Press, Austin.

Gómez Canedo, Lino

1968 Primeras exploraciones y poblamiento de Texas (1686-1694). PITM, Historia 6.

Guada 7upe, Joseph de

$1754 a$ Memorial Precentado a1 Governador. . . de 1a Prov. ${ }^{a}$ de S.n Francisco de Coahuila. AGI, Historia 29 (BTHCA, 2Q178, Vo1. 348:91-92).

1754b Querel1a de San Juan Capistrano por los agravios y Daños que le cause Vizarrón. Archivo del Colegio de la Santa Cruz de Querétaro, K N 15, Leg. 4 (BTHCA, 2Q237, Vo1. 768:172-183).

1754c Fr. Joseph de Guadalupe, Santiago de 1a Moncloba, Junio 21, 1754. Pedimento de que se restituyer los indios Pamaques, Pagnacanes y Piguiques a 1a Mision de San Juan Capistrano del Presidio San Antonio de Béjar. SFGA (BTHCA, 2Q249, Vol. 5:176).

Habig, Marion A.

1968 The Alamo Chain of Missions: A History of San Antonio's Five oed Missions. Franciscan Herald Press, Chicago.

Haggard, J. Villasana

1941 Handbook for Translators of Spanish Historical Documents. Austin.

1942 Spain's Indian Policy in Texas: Translations from the Bexar Archives. SHQ 46(1):75-82.

Hallenbeck, Cleve

1940 Alvar Nünez Cabeza de Vaca: The Journey and Route of the First European to Cross the Continent of North America, 1534-1536. Glendale. 
Harris, John

1705 Navigantium atque Itinerantium Bibliotheca. Or, A Compleat Collection of Voyages and Travels. 2 vols. London.

Hedrick, Basil C., and Carroll L. Riley

1974 The Journey of the Vaca Party: The Account of the Narváez Expedition, 1528-1536, as Related by Gonzalo Fernández de oviedo y Valdés. Southern Illinois university, University Museum Studies 2. Carbondale.

Helm, Mary S.

1884 Scraps of Early Texas History. Austin.

Hendricks, Sterling Brown

1919 The Somervell Expedition to the Rio Grande, 1842. SHQ 23(2): $112-140$.

Hodge, Frederick W., ed.

1907 The Narrative of Alvar Núnez Cabeza de Vaca. In Spanish Explorations in the Southern United States, 1528-1543:3-126. New York.

1907

1910 Handbook of American Indians North of Mexico. BAE-B 30. 2 vols.

1953 The Narrative of Alvar Núnez Cabeza de Vaca. In Spanish Explorers in the Southern United States, 1528-1543. New York.

Holley, Mary Austin

1836 Texas. Lexington, Kentucky.

Holz, Robert K., Mildred P. Mayha 11, and Samuel W. Newman

1972 Texas and Its History. Graphic Ideas, Inc., Austin-Dallas.

Hoyo, Eugenio del

1960 Vocablos de 1a Lengua Quinigua de los Indios Borrados del Noreste de México. Humanitas 1(1):486-515. Universidad de Nuevo León, Monterrey.

Kelley, J. Charles

1952 Some Geographic and Cultural Factors Involved in MexicanSoutheastern Contacts. In Sol Tax, Indian Tribes of Aboriginal America. Proceedings of the 29th Congress of Americanists:139-144. Chicago. 
Kownslar, A11an 0.

1972 The Texans: Their Land and History. American Heritage Publishing Company, New York.

Kress, Margaret Kinney, and Mattie Austin Hatcher

1931 Diary of a Visit of Inspection of the Texas Missions Made by Fray Gaspar José de Solis in the Year 1767-68. SHQ 35(1):28-76.

Krieger, Alex D.

1955 Un Nuevo Estudio de la Ruta Seguida por Cabeza de Vaca, a Través de Norte América. Disertación, Doctor de Ciencias, Universidad Nacional Autónoma de México. México.

1956 Food Habits of the Texas Coastal Indians in the Early Sixteenth Century. Bulletin of the Texas Archeological Society 27:47-58.

1961 The Travels of Alvar Núñez Cabeza de Vaca in Texas and Mexico, 1534-1536. In Homenaje a Pablo Martinez del Rio en al XXV Aniversario de Los Origines Americanos:459-474. México.

Ladrón de Guevara, Don Antonio

1969 Noticias de los poblados de que se componen el Nuevo Reino de León, Provincia de Coahuila, Nueva-Extremadura, y la de Texas (1739). Edición de Andrés Montemayor Hernández. PITM, Historia 10.

León, Alonso, Juan Bautista Chapa y el Gral. Fernando Sanchez de Zamora

1961 Historia de Nuevo León, con Noticias sobre Coahuila, Tamaulipas, Texas y Nuevo México. Estudio preliminar y notas de Israel Cavazos Garza. Biblioteca de Nuevo León 1. Centro de Estudios Humanisticos de la Universidad de Nuevo León. Monterrey.

Lynn, Warren M., Daniel E. Fox, and Nancy O'Malley

1977 Cultural Resource Survey of Choke Canyon Reservoir, Live Oak and McMullen Counties; Texas, with appendix by Marshal1 $\mathrm{C}$. Johnston and Deborah J. Darr. Texas Historical Commission, Archeological Survey Report 20. Austin.

Maas, P. Otto

1915 Viajes de Misioneros Franciscanos á la Conquista del Nuevo México. Sevilla. 
Margil (de Jesús), Antonio

1719 Letter to the Marqués de Aguayo, Dec. 26, 1719, from Mission San Antonio de Valero. In Testim. ${ }^{\circ}$ de la posson y Misson de $\mathrm{S}^{\mathrm{n}}$ Joseph. AGI, Audiencia de Guadalajara, 67-3-11. Dunn Transcripts (BTHCA):12-25.

1720 (Opposition to founding Mission San José.) Archivo del Colegio de la Santa Cruz de Querétaro, KN 5, Leg. 4 (BTHCA, 2Q237, vol. $766: 11-12$ ).

Marqués San Miguel de Aguayo

1720 (Decree for the founding of Mission San José.) In Testim. ${ }^{0}$ de $S^{n}$ Joseph. AGI, Audiencia de Guadalajara, 67-3-11. Dunn Transcripts, 1710-1738 (BTHCA Vol. 23:12-25).

Martínez, Ignacio

1754 Certificación de fe de bautismo de indios bautizados en San Juan Capistrano. Dada por el P. Ignacio Martinez en San Antonio de Béjar, abri1 30. SFGA (BTHCA, 2Q249, Vo1. 5:168-169).

Matamoros Archives

MS In BTHCA (copy).

Mayha11, Mildred P.

1965 Indian wars in Texas. Texian Press, Waco.

Morfi, Juan Agustín

1935 History of Texas, 1673-1779. Translated and annotated by Carlos Eduardo Castañeda. Quivira Society Publications 6. 2 vols. Albuquerque.

Murphy, Retta

1937 The Journey of Pedro de Rivera, 1724-1728. SHQ 41(2):125-141.

Nacogdoches Archives

MS In BTHCA (copy).

Newcomb, W. W., Jr.

1961 The Indians of Texas from Prehistoric to Modern Times. University of Texas Press, Austin.

Núñez Cabeza de Vaca, Álvar

1542 La relación que dio Álvar Nünez Cabeza de Vaca. . . Zamora. Photostatic copy, BTHCA. 
1555 La Relación y Comentarios del Governa Álvar Núñez Cabeza de Vaca, de lo acaeicido en las dos Jornadas qe hizo a las Indias. Valladolid. Photocopy in BTHCA.

1870 Relación. In Documentos Inéditos del Archivos de los Indias, Tomo XIV:269-279.

1963 Schiffbrüche: Bericht über die Unglücksfahrt der NarvaezExpedition nach de Südküste Nordamerikas, 1527-1536, übersetzung. Einleitung und wissenschaftliche Bearbeitung von Franz Termer. München.

1971 Naufragios y comentarios. Quinta edición. Espasa-Calpe, S.A. Madrid.

Oberste, William H.

1942 History of Refugio Mission. Refugio, Texas.

01 ivares, Antonio de San Buenaventura

1720 Oposición a 1a fund. ${ }^{n}$ de la Miss. ${ }^{n}$ de $S^{n}$ Joseph del rio de $S .^{n}$ Ant. ${ }^{\circ}$ Ano de 1720. Archivo del Colegio de la Santa Cruz de Querétaro, KN 5, Leg. 4 (BTHCA, 2Q237, Vo1. 766:9-11).

Orobio y Bazterra, Prudencio

1737 (Auto) NA, BTHCA, 2Q292, Vol. 839:44-45.

1738 (Report) NA, BTHCA, 2Q292, Vo1. 839:46.

Orozco y Berra, Manue1

1864 Geografía de las Lenguas y Carta Etnográfica de México. México. Oviedo y Valdés, Gonzalo Fernández de

$1851-$

1855 Historia General y Natural de las Indias. Tomo I-IV. Madrid.

Pearson, Jim B., Ben H. Procter, and William B. Conway

1972 Texas: The Land and Its People. Hendrick-Long Publishing Company, Dallas.

Pérez de Mesquía, Pedro

1731 Carta al Señor Marq. ${ }^{5}$ de Casa-Fuerte, Virrey de esta Nueva Espana, Mayo 4 de 1731. AGN, Provincias Internas 236 (BTHCA, 2Q215, Vol. 531:36-40). 
Pimentel, Francisco

1875 Cuadro descriptivo y comparativo de las lenguas indigenas de Mexico o tratado de filología Mexicana. Tomo II. México.

Porti110, Esteban L.

1886 Apuntes para la Historia Antigua de Coahuila y Texas. Saltillo.

Powe1 1, J.W.

1891 Indian Linguistic Families of America North of Mexico. Seventh Annual Report of the Bureau of Ethnology, 1885-86. Washington, D.C.

Proceedings

1752 Initial proceedings for investigation of murders at San Xavier of Father Francisco Joseph Ganzabal and Juan Joseph Zains de Zeballos, Feb. 21-June 14, 1752. BAT, BTHCA, Vol. 24:250-275.

Rábago y Terán, Pedro

1754 (José Guadalupe's case concerning Pamaque et al.) AGN 29 (BTHCA, 2Q178, Vol. 348:92-94).

Ramón, Diego

1707 Diaria de la jornada que executo Sargente M. ${ }^{r}$ Diego Ramón . . . AGN, Provincias Internas 28 (BTHCA, 2Q203, Vol. 466:53-71).

Reese, James $V_{.}$, and Lorrin Kennamer

1972 Texas: Land of Contrast, Its History and Geography. W. S. Benson \& Company, Austin.

Refugio Registers

MS In BTHCA

Revilla Gigedo, Conde de

1966 Informe sobre las Misiones, 1793, e Instrucción Reservada al Marqués de Branciforte, 1794. México.

Rivera, Pedro de

1728 Proyecto y vissita de Presidios hecho el año de $1728 p^{r}$ el Brigadier D. Pedro Rivera. AGN, Provincias Internas 29 (BTHCA, 2Q203, Vo1. 467:4-134). 
Rivera y Villalón, Pedro de

1945 Diario y derrotero de la caminato, visto obcervato en el discurso de visita general de Precidios situadoas en las Provincias Internas de Nueva España. México.

Rodríguez, Joseph Antonio

1755 Fray Joseph Antonio Rodríguez al M. R. ${ }^{\text {mo }}$ R. N. Com. Gral. SFGA (BTHCA, 2Q249, Vol. 5:182-186).

Rodríguez, Vicente

1772 Testimonio de los bienes de la Mission de San Juan Bautista del Rio Grande. SA, BTHCA, 2Q313, Vol. 3:76-134.

Rubîi, Marqués de

1768 Digttamen que de orden Exmo. Señor Marqués de Croix, Virrey de este Reyno expone el Mariscal de Campo Marqués de Rubí. AGI, Audiencia de México, Dunn Transcripts (BTHCA, 2Q140, Vol. 46: 7-61).

Ruecking, Frederick Henry, Jr.

1955 The Coahuiltecan Indians of Southern Texas and Northeastern Mexico. M.A. Thesis, The University of Texas at Austin.

Sandoval, Manuel de

1734 Copy of Residencia of Governor Don Juan Antonio de Busti110 y Zevallos conducted by Governor Don Manue 1 de Sandoval by order of the Marqués of Casafuerte. BAT, BTHCA, 2C321, Vo1. 3:1-213.

San Francisco Solano Baptisms

MS See Valero Registers (included with).

Santa Ana, Benito Fernández

1737 Carta al S. ${ }^{r}$ Cap. ${ }^{n}$ D. ${ }^{n}$ Joseph de Urrutia. AGN, Misiones 21 (BTHCA, 2Q201, Vo 1. 454:380).

1739 (Report) NA (BTHCA, Vol. 1; Nov. 26, 1731-Jan. 12, 1747).

1743 Carta, Marzo 4 de 1743 , de la Mision de 1a Consepz ${ }^{\text {on }}$ de Acuña. AGN, Provincias Internas 236 (BTHCA, 2Q215, Vol. 531:69-75).

Santos, Richard J.

$1966-$

1967 A Preliminary Survey of the San Fernando Archives. Texas Libraries 28(4):152-172. 
Sauer, Cari 0 .

1971 Sixteenth Century North America: The Land and the People as Seen by the Europeans. University of California Press, Berkeley.

Schroeder, Albert $\mathrm{H}$.

1960 A Study of the Apache Indians. Part III. The Mescalero Apaches. Santa Fe.

Sevillano de Paredes, Miguel

1727 Visita de los Misiones del Rio Grande del Norte por Fr. Miguel Sevillano de Paredes en 15 de Octubre de 1727. AGN, Historia 29 (BTHCA, 2Q173, Vol. 348:35-68).

Shelby, Charmion Claire

1923 St. Denis's Declaration Concerning Texas in 1717. SHQ 26(3): 165-183.

Sjoberg, Andrée F.

1953 Lipan Culture in Historical Perspective. Southwestern Journal of Anthropology 9(1):76-98.

Smith, Buckingham, translator

1851 The Narrative of Alvar Nüñez Cabeza de Vaca. Washington.

1871 Relation of Álvar Nüñez Cabeza de Vaca. New York.

Steck, Francis Borgia

1932 Forerunners of Captain de León's Expedition to Texas, 1670-1675. SHQ 36(1): 1-28.

Stilles, Henry Reed, ed.

1906 Joutel's Journal of La Salle's Last Voyage, 1684-7. Albany.

Swanton, John R.

1940 Linguistic Material from the Tribes of Southern Texas and Northeastern Mexico. BAE-B 127.

1942 Source Material on the History and Ethnology of the Caddo Indians. BAE-B 132 .

1952 The Indian Tribes of North America. BAE-B 145. 
Terre11, John U.

1962 Journey into Darkness. New York.

Tous, Gabriel

1930 The Espinosa-01ivares-Aguirre Expedition of 1709: Espinosa's Diary. PTCHS 1(3).

Troike, Rudolph C.

1959 A Descriptive Phonology and Morphology of Coahuilteco. Unpublished doctoral dissertation, The University of Texas at Austin.

Tunne11, Curtis D., and W. W. Newcomb, Jr.

1969 A Lipan Apache Mission: San Lorenzo de 1a Cruz, 1762-1771. Bulletin of the Texas Memorial Museum 14.

Turner, B. L.

1959 The Legumes of Texas. University of Texas Press, Austin.

Uribe Larrea, Tomás

1958 Informe al Reverendisimo Padre Comisario General sobre Misiones . . Año de 1754. Boletín del Archivo de la Nación 29(3):463-480. México.

Valdéz, Juan

1720 Letter to the Marqués de Aguayo, giving an account of the founding of Mission San José. In Testimo de la Poss ${ }^{n}$ y Misson de $S^{n}$ Joseph, AGN, Audiencia de Guadalajara, 67-3-11, Dunn Transcripts (BTHCA, Vol. 23:12-25).

Valero Registers

MS Baptismal, marriage, and burial registers for Mission San Antonio de Valero are in the San Fernando Archives, San Antonio, Texas (see Santos, 1966-1967). Photostat and microfilm copies are in the Texas Catholic Archives, Austin, Texas.

Vergára, Fray Gabrie1 de

1965 El cuadernillo de la Tengua de los indios Pajalates (1732) por Fray Gabriel de Vergara y el confesario de indios en lengua Coahuilteca. Edición de Eugenio del Hoyo. Perfil Biográfico de Fray Gabriel de Vergara por Lino Gómez Canedo. PITM, Historia 3. Monterrey. 
Wagner, H. R.

1924 The Spanish Southwest, 1542-1794. Berkeley.

Walters, Paul H.

1951 Secularization of the La Bahía Missions. SHQ 54(3):287-300. Weddle, Robert S.

1968 San Juan Bautista: Gateway to Spanish Texas. University of Texas Press, Austin.

Weddle, Robert S., and Robert H. Thonhoff

1976 Drama \& Conflict: The Texas Saga of 1776. Madrona Press, Austin. Wheat, Carl I.

1957 Mapping the Transmississippi West, 1540-1861. 2 vols. San Francisco. Williams, Albert C.

1939 The Route of Cabeza de Vaca in Texas: A Study in Historiography. Unpublished M.A. Thesis, The University of Texas at Austin.

Ximenes, Ben Cuellar

1963 Gallant Outcasts. San Antonio.

Ysasmende (Isasmende), Pedro de

1737 Fray Pedro de Ysasmende Pr Appco y Mtro del Mision dentro P. S. Francisco de la Espada de esta Prova. de Texas en la mejor forma aya lugar digo asi. NA, BTHCA, 2Q292, Vo1. 839:41-42.

1739 (Report to Governor Prudencio de Orovio.) NA, BTHCA, 2Q292, Vo1. 839:47-48. 